\title{
Rhodium-Catalyzed Asymmetric Hydrogenation of Olefins with PhthalaPhos, a New Class of Chiral Supramolecular Ligands
}

\author{
Luca Pignataro, ${ }^{*[a]}$ Michele Boghi, ${ }^{[a]}$ Monica Civera, ${ }^{[a]}$ Stefano Carboni, ${ }^{[b]}$ \\ Umberto Piarulli, ${ }^{* b]}$ and Cesare Gennari*[a]
}

\begin{abstract}
A library of 19 binol-derived chiral monophosphites that contain a phthalic acid diamide group (PhthalaPhos) has been designed and synthesized in four steps. These new ligands were screened in the rhodium-catalyzed enantioselective hydrogenation of prochiral dehydroamino esters and enamides. Several members of the library showed excellent enantioselectivity with methyl 2 -acetamido acrylate (6 ligands gave $>97 \%$ ee), methyl (Z)-2acetamido cinnamate (6 ligands gave $>94 \% e e$ ), and $N$-(1-phenylvinyl)acetamide ( 9 ligands gave $>95 \%$ ee), whilst only a few representatives af-
\end{abstract}

forded high enantioselectivities for challenging and industrially relevant substrates $N$-(3,4-dihydronaphthalen-1yl)-acetamide ( $96 \%$ ee in one case) and methyl (E)-2-(acetamidomethyl)-3phenylacrylate ( $99 \%$ ee in one case) In most cases, the new ligands were more active and more stereoselective than their structurally related monodentate phosphites (which are devoid of functional groups that are capable of

Keywords: asymmetric catalysis hydrogenation • olefins $\cdot$ rhodium . supramolecular chemistry

\section{Introduction}

The rhodium-catalyzed asymmetric hydrogenation of prochiral olefins is one of the most-intensely studied stereoselective reactions, and has been the object of uninterrupted interest from chemists over the last forty years. ${ }^{[1]}$ Unlike many other enantioselective catalytic processes, ${ }^{[2]}$ this reaction has become a well-established methodology for the industrial preparation of chiral building blocks, ${ }^{[3]}$ thanks to its high efficiency and simple experimental setup. Although chiral monophosphines were used as ligands in the first examples

[a] Dr. L. Pignataro, M. Boghi, Dr. M. Civera, Prof. Dr. C. Gennari Università degli Studi di Milano

Dipartimento di Chimica Organica e Industriale

Centro Interdipartimentale CISI

Istituto di Scienze e Tecnologie Molecolari (ISTM) del CNR

Via G. Venezian, 21, 20133, Milano (Italy)

Fax: (+39) 02-50314072

E-mail: luca.pignataro@unimi.it cesare.gennari@unimi.it

[b] Dr. S. Carboni, Prof. Dr. U. Piarulli Università degli Studi dell'Insubria Dipartimento di Scienze Chimiche e Ambientali Via Valleggio, 11, 22100, Como (Italy) Fax: $(+39)$ 031-2386449

E-mail: umberto.piarulli@uninsubria.it

Supporting information for this article is available on the WWW under http://dx.doi.org/10.1002/chem.201102018.

\begin{abstract}
hydrogen-bonding interactions). Control experiments and kinetic studies were carried out that allowed us to demonstrate that hydrogen-bonding interactions involving the diamide group of the PhthalaPhos ligands strongly contribute to their outstanding catalytic properties. Computational studies carried out on a rhodium precatalyst and on a conceivable intermediate in the hydrogenation catalytic cycle shed some light on the role played by hydrogen bonding, which is likely to act in a substrate-orientation effect.
\end{abstract}

of asymmetric hydrogenation, ${ }^{[4]}$ for some thirty years since the pioneering work of Knowles and Kagan chiral bis-phosphorus ligands have played a major role in this reaction. ${ }^{[5]}$ However, around the year 2000, the dominance of bidentate ligands started being questioned following the work reported by Guillen and Fiaud, ${ }^{[6]}$ and by the groups of Pringle, ${ }^{[7]}$ Reetz ${ }^{[8]}$ de Vries, and Feringa. ${ }^{[9]}$ They found that rhodium complexes of simple, easy-to-make chiral monodentate ligands (the most important being phosphonites, phosphites, and phosphoramidites ${ }^{[10]}$ catalyzed the hydrogenation of prochiral olefins with comparable or higher enantioselectivities than those obtained with the related bidentate systems. These findings boosted the interest of many research groups in chiral monodentate ligands, whose easy preparation makes them particularly attractive for industrial applications. In 2003, Reetz and co-workers ${ }^{[11]}$ and Feringa and coworkers $^{[12]}$ independently reported that binary mixtures of monodentate P ligands can lead to higher conversions and enantioselectivities in rhodium-catalyzed olefin hydrogenations than those obtained with the individual ligands alone. This improvement occurs when the heterocomplex $\left[\mathrm{RhL}^{a} \mathrm{~L}^{\mathrm{b}}\right]$ is more active and stereoselective than the two homocomplexes $\left[R h L^{a} L^{a}\right]$ and $\left[R_{h} L^{b} L^{b}\right]$. This methodology, later extended to other reactions, ${ }^{[13]}$ is of great industrial interest because it allows for the rapid combinatorial screening of a number of catalytic systems with a much-larger scope than just the number of ligands employed. However, in principle, the simultaneous presence of three complexes $\left(\left[\mathrm{RhL}^{\mathrm{a}} \mathrm{L}^{\mathrm{b}}\right]\right.$, 
$\left[R h L^{a} L^{a}\right]$, and $\left.\left[R h L^{b} L^{b}\right]\right)$ in the reaction environment lowers the overall enantioselectivity of the process, unless the activity of the most stereoselective complex is considerably higher than that of the other two. This limitation stimulated several research groups to develop methods for achieving the exclusive formation of the heterocomplexes, $\left[\mathrm{RhL}^{\mathrm{a}} \mathrm{L}^{\mathrm{b}}\right]$. Non-covalent interactions between ligands soon appeared as the best strategy ${ }^{[14]}$ for achieving this result, and supramolecular phosphorus ligands became the object of increasing interest ${ }^{[15]}$ that soon went beyond the selective formation of heterocomplexes. Thus, several research groups began developing monodentate $\mathrm{P}$ ligands that possessed a secondary functional group (besides the metal-coordinating phosphorus atom) that was capable of non-covalent interactions (hydrogen bonding, ${ }^{[16,17]}$ coordinative bonding, ${ }^{[18]}$ and others $\left.{ }^{[19]}\right)$. Such non-covalent interactions can play two major roles: 1) Holding two ligands together that are coordinated to the same metal center to afford a "supramolecular bidentate ligand". ${ }^{[16,18,19]}$ Whether these supramolecular ligands are made up of different or identical ligands, ligand-ligand interactions create highly organized environments that have a different conformational space from that of the monodentate ligand complexes. 2) Binding the reaction substrate, ${ }^{[17,20]}$ in order to position it correctly relative to the catalytic metal center; this orientation is analogous to what is observed in natural metalloenzymes. These approaches, which have also been applied together within the same catalytic system, ${ }^{[17 \mathrm{~g}]}$ both result in an improvement in the activity and/or regio- and stereoselectivity of the ligands compared to their structurally simplified monodentate ligands. In recent years, our research group has provided several contributions both to the use of combinations of monodentate ligands (applied to asymmetric hydrogenation ${ }^{[14,21 a]}$ and other reactions $\left.{ }^{[21 \mathrm{~b}-\mathrm{d}]}\right)$ and to the development of supramolecular ligands for asymmetric hydrogenation. ${ }^{[19 \mathrm{c}, \mathrm{d}]}$ As part of our continued interest in the field of supramolecular catalysis, herein, we report a full account on the development of a new class of chiral supramolecular phosphite ligands (PhthalaPhos) ${ }^{[22]}$ and their application to the rhodium-catalyzed enantioselective hydrogenation of prochiral dehydroamino esters and enamides. We also consider the effects of hydrogen-bonding interactions on the catalytic properties of the ligands using spectroscopic and computational studies and reaction kinetics.

\section{Results and Discussion}

Ligand design: Supramolecular bidentate ligands that rely on hydrogen-bonding interactions are arguably the most practical and amenable ligands for combinatorial screening in catalysis. ${ }^{[16]}$ Indeed, the functional groups that are ca- pable of this kind of interaction (e.g. amides, ureas, guanidines) are usually easy to make, stable, and-most importantly-form hydrogen bonds spontaneously and reversibly in solution. As a consequence, preliminary steps in the preparation of supramolecular bidentate ligands are not required, and such bidentate ligands are formed by simply combining the metal source with properly functionalized monodentate ligands in the reaction environment. Therefore, we set out to design a new class of chiral-binol-derived monophosphites that are capable of forming corresponding supramolecular ligands from hydrogen-bonding interactions between amide groups. We reasoned that primary bisamides of phthalic acid were particularly well-suited to this purpose, thanks to the following properties: 1) they can be easily prepared by a modular approach starting from cheap phthalic anhydride, where different amines can be employed to form the two amide groups; and 2) they can act as both a donor and as an acceptor for the formation of multiple hydrogen bonds. In particular, we expected that two hydrogen bonds could form between two phthalamide-functionalized phosphites coordinated to a metal to create a rigid and stereodefined environment around it (see Scheme 1B). Based on these interesting features, we decided to prepare a library of binol monophosphites, called "PhthalaPhos", which would feature the following sites of diversity (Scheme 1A): 1) the linker between the phosphite and the phthalamide moiety, 2) the substitution on the binaphtholic portion of the phosphite group, and 3) the ancillary amide group, namely the amide group that is not connected to the phosphite group.

Preparation of the PhthalaPhos ligand library: The ligands (shown in Scheme 2) were prepared following an easy and reliable four-step synthesis (Scheme 3) involving only one or two chromatographic purification steps: phthalic anhydride was allowed to react with a primary amine to give the phthalic acid mono amides $\mathbf{1 a}$ and $\mathbf{1 b}$ in $94-98 \%$ yield. ${ }^{[23]}$ Dehydration of amides $\mathbf{1 a}$ and $\mathbf{1 b}$ in the presence of trifluoroacetic anhydride gave phthalisoimides $\mathbf{2 a}$ and $\mathbf{2 b}$ ( $97 \%$ and $99 \%$ yield, respectively), whose reaction with various amino alcohols led to phthalic acid diamides $\mathbf{3 a}-\mathbf{3 l}$ and

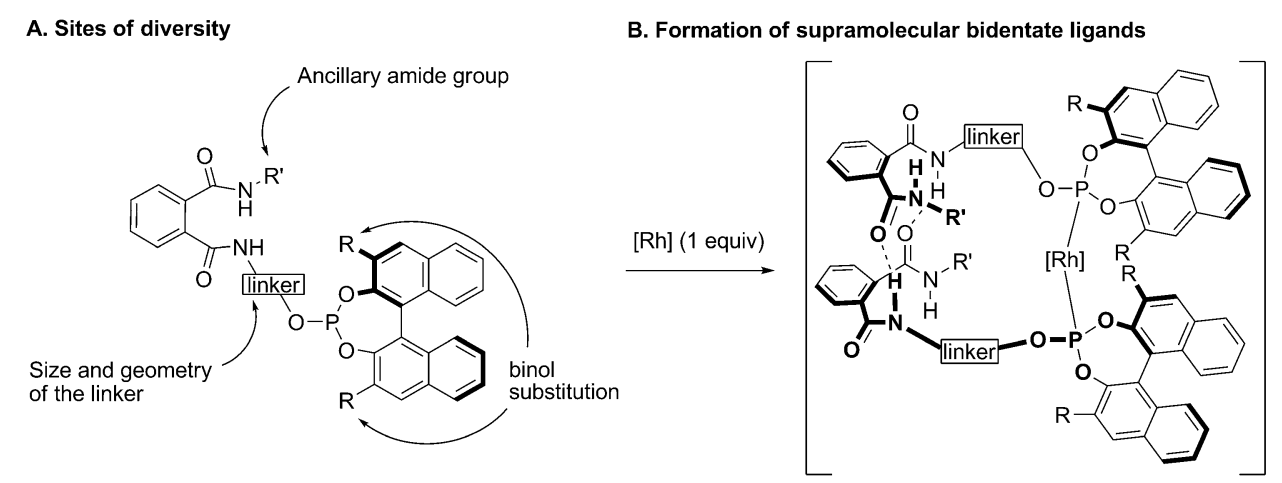

Scheme 1. A) PhthalaPhos ligands: general structure and possible diversification points; B) formation of supramolecular bidentate ligands in the presence of a rhodium source. 

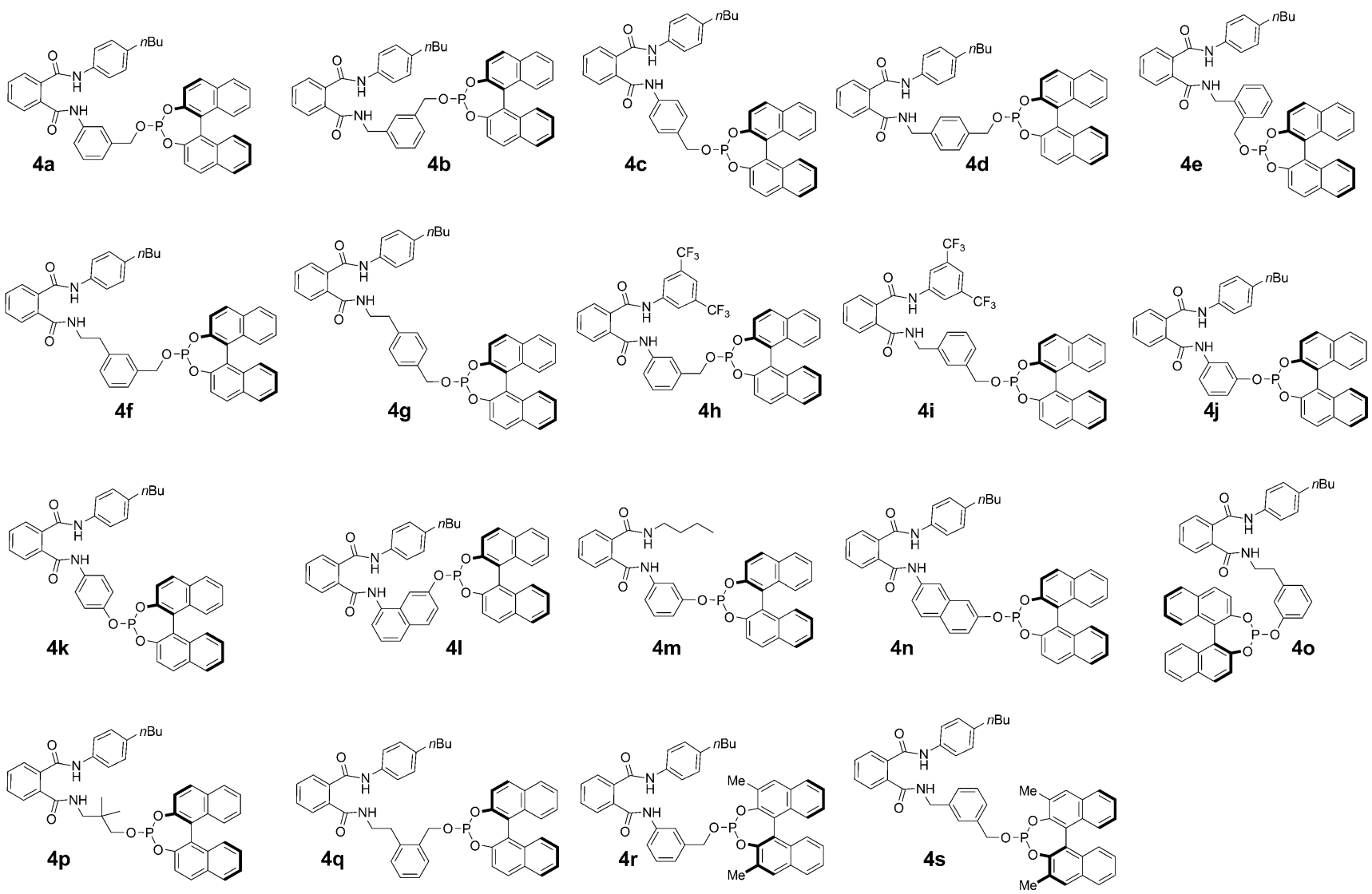

Scheme 2. The PhthalaPhos ligand library.<smiles>[R]NC(=O)c1ccc(C)cc1C(=O)O</smiles><smiles>[R]N=C1OC(=O)c2ccc(C)cc21</smiles>

1a: $\mathrm{R}^{\prime}=4-(n \mathrm{Bu})-\mathrm{C}_{6} \mathrm{H}_{4}$ 1b: $\mathrm{R}^{\prime}=3,5-\mathrm{bis}\left(\mathrm{CF}_{3}\right)-\mathrm{C}_{6} \mathrm{H}_{3}$ 2a: $\mathrm{R}^{\prime}=4-(n B u)-\mathrm{C}_{6} \mathrm{H}_{4}$
2b: $\mathrm{R}^{\prime}=3,5-\mathrm{bis}\left(\mathrm{CF}_{3}\right)-\mathrm{C}_{6} \mathrm{H}_{3}$

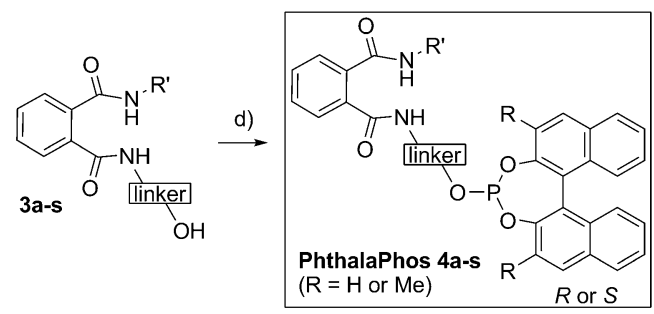

Scheme 3. General synthesis of PhthalaPhos ligands: a) Phthalic anhydride, $\mathrm{CHCl}_{3}$, reflux, $94-98 \%$ yield; b) $\left(\mathrm{CF}_{3} \mathrm{CO}\right)_{2} \mathrm{O}, \mathrm{Et}_{3} \mathrm{~N}, 1,4$-dioxane, or THF, $0{ }^{\circ} \mathrm{C}$ to RT, $97-99 \%$ yield; c) amino alcohol, THF, RT, 58-94\% yield; d) $(S)$-binol-PCl or $(R)$-3,3'-dimethyl-binol-PCl, $\mathrm{Et}_{3} \mathrm{~N}$, THF, RT, $47-78 \%$.

3n-3 s (58-94\% yield), respectively. ${ }^{[24]}$ Some of the amino alcohols employed are commercially available, whilst the others were easily prepared as described in the Supporting Information. The diamide monoalcohols $\mathbf{3 a} \mathbf{a}-\mathbf{3} \mathbf{s}$ were reacted with binol-derived chlorophosphites ${ }^{[25]}$ to give PhthalaPhos ligands 4a-s (47-78\% yield). Diamide-phenol $3 \mathbf{m}$ (a precursor of phosphite $\mathbf{4 m}$ ) could not be prepared via the corresponding $n$-butyl-substituted phthalisoimide (unstable). However, it was readily obtained from compound $\mathbf{1 c}$ and 3 aminophenol in the presence of $N$-(3-dimethylaminopropyl)- $N$ '-ethylcarbodiimide hydrochloride (EDC) and 1-hydroxybenzotriazole (HOBT; Scheme 4).<smiles>CCCCNC(=O)c1ccccc1C(=O)Nc1cccc(O)c1</smiles>

Scheme 4. Synthesis of the diamide-phenol 3m: a) Phthalic anhydride, $\mathrm{CHCl}_{3}$, reflux, $85 \%$; b) EDC, HOBT, 3-aminophenol, $\mathrm{CH}_{2} \mathrm{Cl}_{2}, 0^{\circ} \mathrm{C}$ to RT, $71 \%$.

Catalytic screening of the library: We set out to investigate the catalytic properties of our new ligands in the rhodiumcatalyzed enantioselective hydrogenation of several dehydroamino esters and enamides. In order to evaluate the effect of the diamide group on catalytic behavior, two simple monodentate binol-phosphites (structurally related to our ligands, but devoid of functional groups capable of supramolecular interactions) were used as standards in the 
catalyst screen: phenyl phosphite $\mathbf{5 a}^{[26]}$ and benzyl phosphite $\mathbf{5 b}^{[27]}$ (Scheme 5). First, we assessed the catalytic properties of the new ligands in the hydrogenation of three classical
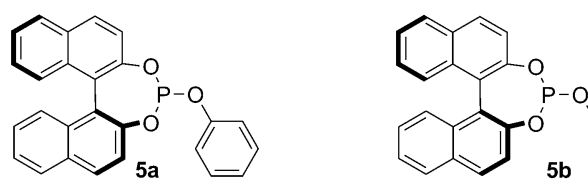

Scheme 5. Monodentate phosphites employed as standards in the catalytic screening.

benchmark substrates: methyl 2-acetamidoacrylate (S1), methyl (Z)-2-acetamidocinnamate (S2), and $N$-(1-phenylvinyl)acetamide (S3). Subsequently, the library was also screened in the hydrogenation of two more-challenging substrates: cyclic enamide $\mathbf{S 4}$ [ $N$-(3,4-dihydronaphthalen-1-yl)acetamide] and $\beta^{2}$-dehydro aminoester S5 $[(E)$-methyl 2(acetamidomethyl)-3-phenylacrylate], which are both industrially relevant compounds. ${ }^{[17 \mathrm{~g}]}$ The best results obtained with each substrate are shown in Tables $1-5$, respectively. The full set of results is represented graphically in Figure 1, and tabulated in the Supporting Information. In the hydrogenation of methyl 2-acetamidoacrylate (S1; Table 1, Figure 1) excellent results were obtained, with 11 ligands giving $>93 \%$ ee and six ligands giving $>97 \%$ ee. Remarkably, monodentate phosphites $\mathbf{5 a}$ and $\mathbf{5 b}$ gave only $84 \%$ and $90 \% e e$, respectively, for this substrate, thus demonstrating the important role played by the diamide group in determin-
Table 1. Selected results of the screening of the PhthalaPhos library in the enantioselective hydrogenation of methyl 2-acetamidoacrylate (S1) ${ }^{\left[{ }^{[a]}\right.}$

$$
\begin{aligned}
& \text { NHAc } \quad\left[\mathrm{Rh}(\mathrm{cod})_{2} \mathrm{BF}_{4}\right] / \mathrm{L} \quad \mathrm{NHAc}
\end{aligned}
$$

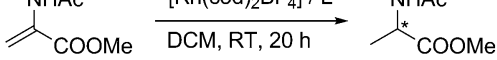

\begin{tabular}{lccr}
\hline Entry & Ligand & Conv. $[\%]^{[\mathrm{b}]}$ & $e e[\%]^{[\mathrm{b}, \mathrm{c}]}$ \\
\hline 1 & $\mathbf{4 a}$ & 100 & $94(R)$ \\
2 & $\mathbf{4 b}$ & 100 & $98(R)$ \\
3 & $\mathbf{4 e}$ & 100 & $>99(R)$ \\
4 & $\mathbf{4}$ & 100 & $98(R)$ \\
5 & $\mathbf{4}$ & 100 & $98(R)$ \\
6 & $\mathbf{4} \mathbf{p}$ & 100 & $98(R)$ \\
7 & $\mathbf{4 q}$ & 100 & $>99(R)$ \\
8 & $\mathbf{5 a}$ & 100 & $84(R)$ \\
9 & $\mathbf{5 b}$ & 100 & $90(R)$ \\
\hline
\end{tabular}

[a] Reaction conditions: substrate/ligand/[Rh( $\left.\operatorname{cod})_{2} \mathrm{BF}_{4}\right]=100: 2.2: 1$, solvent $=\mathrm{CH}_{2} \mathrm{Cl}_{2}, c_{0}(\mathbf{S 1})=0.048 \mathrm{M}, T=25^{\circ} \mathrm{C}$. [b] Determined by $\mathrm{GC}$ analysis with a chiral capillary column (MEGADEX DACTBS $\beta$, diacetyl-tert-butylsilyl- $\beta$-cyclodextrin). [c] Assignment based on comparison of GC retention times with $\mathbf{5 a}$, whose stereochemical preference is known. ${ }^{[26]}$

ing the catalytic behavior of the PhthalaPhos ligands. The same conclusion can be drawn from the results of the screen of ligands with substrate S2 (Table 2, Figure 1), in which six ligands gave $>94 \%$ ee and three ligands gave $>97 \% e e e^{[28]}$ whilst the reference ligands afforded only moderate enantioselectivities (5a gave $70 \%$ ee and $\mathbf{5 b} 83 \%$ ee). Very good results were also obtained in the screen of ligands with $\mathrm{N}$ (1-phenylvinyl)acetamide $(\mathbf{S 3}$; best results shown in Table 3): nine ligands gave $>95 \%$ ee, four ligands gave

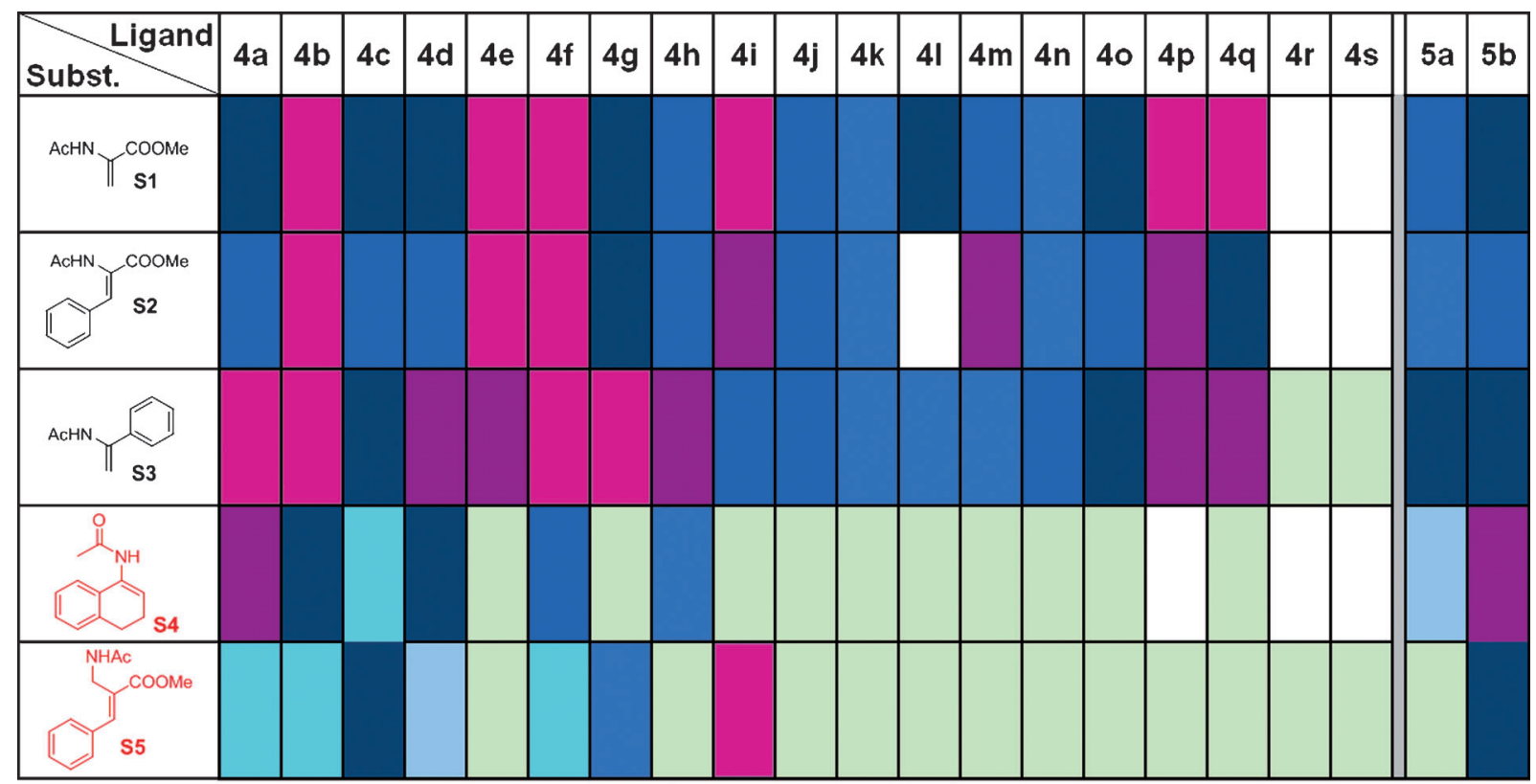

\begin{tabular}{|c|c|c|c|c|c|c|c|c|c|}
\hline Key & & & & & & & & & \\
\hline ee $(\%)$ & $<50$ & $50-59$ & $60-69$ & $70-79$ & $80-89$ & $90-94$ & $95-97$ & $>97$ & No react. \\
\hline
\end{tabular}

Figure 1. Diagram representing the full set of results from the PhthalaPhos ligand screening with substrates S1-S5. 
Table 2. Selected results of the screening of the PhthalaPhos library in the enantioselective hydrogenation of methyl $(Z)$-2-acetamidocinnamate (S2) ${ }^{[\mathrm{a}]}$

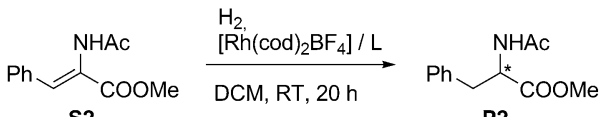

S2 $\quad$ P2

\begin{tabular}{lcccl}
\hline Entry & Ligand & $P[\mathrm{bar}]$ & ${\text { Conv. }[\%]^{[\mathrm{b}]}}$ & $e e[\%]^{[\mathrm{b}, \mathrm{c}]}$ \\
\hline 1 & $\mathbf{4 b}$ & 1 & 100 & $98(R)$ \\
2 & $\mathbf{4 e}$ & 1 & 86 & $98(R)$ \\
3 & $\mathbf{4 e}$ & 12 & 100 & $97(R)$ \\
4 & $\mathbf{4 f}$ & 1 & 100 & $99(R)$ \\
5 & $\mathbf{4 i}$ & 1 & 100 & $97(R)$ \\
6 & $\mathbf{4 p}$ & 1 & 91 & $97(R)$ \\
7 & $\mathbf{4 p}$ & 12 & 100 & $96(R)$ \\
8 & $\mathbf{5 a}$ & 1 & 25 & $73(R)$ \\
9 & $\mathbf{5 a}$ & 12 & 100 & $70(R)$ \\
10 & $\mathbf{5 b}$ & 1 & 100 & $83(R)$ \\
\hline
\end{tabular}

[a] Reaction conditions: substrate/ligand $/\left[\mathrm{Rh}(\operatorname{cod})_{2} \mathrm{BF}_{4}\right]=100: 2.2: 1$, solvent $=\mathrm{CH}_{2} \mathrm{Cl}_{2}, c_{0}(\mathbf{S 2})=0.048 \mathrm{M}$ (when $P=1$ bar) or $0.024 \mathrm{M}$ (when $P=$ 12 bar), $T=25^{\circ} \mathrm{C}$. [b] Determined by HPLC equipped with a chiral column (Daicel Chiralpak AD-H). [c] Assigned by comparison of the sign of optical rotation with literature data. ${ }^{[28]}$

Table 3. Selected results from a screen of the PhthalaPhos library in the enantioselective hydrogenation of $N$-(1-phenylvinyl)acetamide (S3) ${ }^{[a]}$

$$
\begin{aligned}
& \underset{\sim}{\mathrm{NHAc}} \stackrel{\substack{\mathrm{H}_{2}(5 \mathrm{bar})_{2} \\
\left[\mathrm{Rh}(\operatorname{cod})_{2} \mathrm{BF}_{4}\right] / \mathrm{L}}}{\mathrm{NHAC}} \\
& \text { S3 P3 }
\end{aligned}
$$

\begin{tabular}{lccc}
\hline Entry & Ligand & Conv. $[\%]^{[\mathrm{b}]}$ & $e e[\%]^{[\mathrm{b}, \mathrm{c}]}$ \\
\hline 1 & $\mathbf{4 a}$ & 100 & $98(R)$ \\
2 & $\mathbf{4 b}$ & 100 & $98(R)$ \\
3 & $\mathbf{4 e}$ & 100 & $97(R)$ \\
4 & $\mathbf{4 f}$ & 100 & $98(R)$ \\
5 & $\mathbf{4 g}$ & 100 & $99(R)$ \\
6 & $\mathbf{4 h}$ & 100 & $97(R)$ \\
7 & $\mathbf{5 a}$ & 100 & $90(R)$ \\
8 & $\mathbf{5 b}$ & 100 & $94(R)$ \\
\hline
\end{tabular}

[a] Reaction conditions: substrate/ligand/[Rh $\left.(\operatorname{cod}){ }_{2} \mathrm{BF}_{4}\right]=100: 2.2: 1$, solvent $=\mathrm{CH}_{2} \mathrm{Cl}_{2}, c_{0}(\mathbf{S 3})=0.024 \mathrm{M}, T=25^{\circ} \mathrm{C}, P=5$ bar. [b] Determined by GC analysis with a chiral capillary column (MEGADEX DACTBS $\beta$, diacetyl-tert-butylsilyl- $\beta$-cyclodextrin). [c] Assignment based on GC retention times, by comparison with the results obtained for $\mathbf{5 a}$ and $\mathbf{5 b}$, whose stereochemical preference is known. ${ }^{[26,27]}$

$>97 \% e e$. Also in this case, the PhthalaPhos ligands showed higher enantioselectivity than the reference phosphites, although the improvement was less remarkable than in the cases discussed above (ligand 5a gave $90 \%$ ee, $\mathbf{5 b}$ gave $94 \%$ ee). In the reactions of the challenging substrates S4 and S5, only a few members of the library showed high levels of enantioselectivity, unlike the above-described hydrogenation reactions of classic benchmark olefins (Figure 1). The best results from the screen of various ligands with substrate $\mathbf{S 4}$ under 12 bar hydrogen pressure are reported in Table 4. ${ }^{[29]}$ Ligand $\mathbf{4 a}$ promoted the formation of product $\mathbf{P 4}$ with a stereocontrol that rivaled the best literature precedents ( $96 \%$ ee; Table 4 , entry 1$)$; those precedents were obtained using a monodentate phosphoramidite $(84 \%$
Table 4. Selected results of the screening of the PhthalaPhos library in the enantioselective hydrogenation of $N$-(3,4-dihydronaphthalen-1-yl)acetamide (S4). ${ }^{[\mathrm{a}]}$

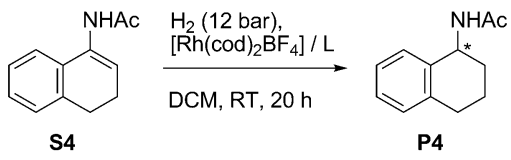

\begin{tabular}{lccc}
\hline Entry & Ligand & Conv. $[\%]^{[\mathrm{b}]}$ & $e e[\%]^{[\mathrm{b}, \mathrm{c}]}$ \\
\hline 1 & $\mathbf{4 a}$ & 100 & $96(R)$ \\
2 & $\mathbf{4 b}$ & 90 & $93(R)$ \\
3 & $\mathbf{4 d}$ & 98 & $92(R)$ \\
4 & $\mathbf{4 f}$ & 46 & $86(R)$ \\
5 & $\mathbf{5 a}$ & 30 & $53(R)$ \\
6 & $\mathbf{5 b}$ & 100 & $96(R)$ \\
\hline
\end{tabular}

[a] Reaction conditions: substrate/ligand/[Rh( $\left.\operatorname{cod})_{2} \mathrm{BF}_{4}\right]=100: 2.2: 1$, solvent $=\mathrm{CH}_{2} \mathrm{Cl}_{2}, c_{0}(\mathbf{S 4})=0.024 \mathrm{M}, T=25^{\circ} \mathrm{C} . P=12$ bar. [b] Determined by GC analysis with a chiral capillary column (MEGADEX DACTBS $\beta$, diacetyl-tert-butylsilyl- $\beta$-cyclodextrin). [c] Assigned by comparison of the sign of optical rotation with literature data. ${ }^{[29]}$

$e e$ at RT, $98 \%$ ee at $\left.-20^{\circ} \mathrm{C}\right)^{[30]}$ and a diphosphine ligand (98\% ee at RT) ${ }^{[31]}$ As expected, reference phosphite 5a was less active and less stereoselective than ligand $4 \mathbf{a}$. On the contrary, despite being unable to form any supramolecular interactions, benzyl phosphite $\mathbf{5} \mathbf{b}$ showed exactly the same level of stereocontrol as ligand $\mathbf{4 a}$ (Table 4, entry 6 vs. entry 1). However, kinetic studies showed that the catalytic rhodium complex of $\mathbf{4 a}$ afforded a faster rate of reaction than that of $\mathbf{5 b}$ (Figure 2). The experiments were set up in parallel using a Parr multireactor, and the conversion values were calculated from the hydrogen uptake. The reactions showed a typical pseudo-first-order kinetic profile, which allowed us to calculate first order $k_{\text {app }}$ values (including catalyst concentration), half-life times $t_{1 / 2}$, and second-order $k$ values (Figure 2; Table 5). As anticipated, the kinetic constant $(k)$ of the rhodium complex of ligand $\mathbf{4 a}$ was almost double that of the rhodium complex of $\mathbf{5 b}$, and the TOF values followed a similar trend. Thus, although ligands $\mathbf{4 a}$ and 5b showed the same levels of stereoselectivity, it is likely that hydrogen-bonding interactions stabilize the tran-

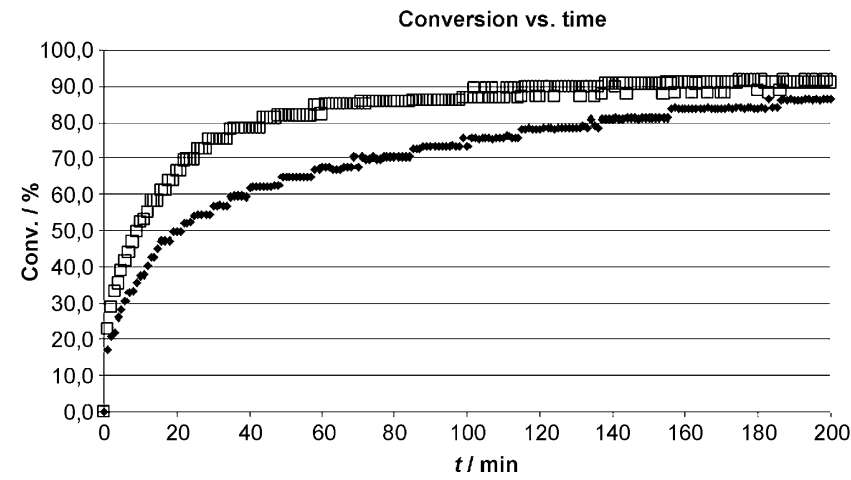

Figure 2. Kinetics of hydrogenation of substrate $\mathbf{S 4}$ catalyzed by the rhodium complexes of ligand $\mathbf{4 a}(\square)$ and ligand $\mathbf{5 b}(\bullet)$, respectively. Solvent $=\mathrm{CH}_{2} \mathrm{Cl}_{2} ; c_{0}(\mathbf{S 4})=0.331 \mathrm{M} ; P_{\text {hydrogen }}=60 \mathrm{bar} ; T=25^{\circ} \mathrm{C}$; catalyst loading $=1 \mathrm{~mol} \%, c_{\text {cat }}=3.31 \mathrm{~mm}$. 
Table 5. Kinetic parameters from the hydrogenation of $N$-(3,4-dihydronaphthalen-1-yl)acetamide (S4) catalyzed by rhodium complexes of ligands $\mathbf{4 a}$ and $\mathbf{5 b}{ }^{[\mathrm{a}]}$

\begin{tabular}{llllc}
\hline Ligand & $k_{\text {app }}\left[\mathrm{min}^{-1}\right]^{[\mathrm{b}]}$ & $t_{1 / 2}[\mathrm{~min}]$ & $k\left[\mathrm{~L} \mathrm{~mol}^{-1} \mathrm{~min}^{-1}\right]^{[\mathrm{b}]}$ & $\mathrm{TOF}\left[\mathrm{h}^{-1}\right]^{[\mathrm{cc}]}$ \\
\hline $\mathbf{4 a}$ & 0.0508 & 13.6 & 15.36 & 234 \\
$\mathbf{5 b}$ & 0.0284 & 24.4 & 8.59 & 180 \\
\hline
\end{tabular}

[a] Solvent $=\mathrm{CH}_{2} \mathrm{Cl}_{2} ; \quad c_{0}(\mathbf{S 4})=0.331 \mathrm{M} ; P_{\text {hydrogen }}=60$ bar ; catalyst loading $=1 \mathrm{~mol} \%, c_{\text {cat. }}=3.31 \mathrm{~mm}$. [b] $k_{\text {app }}=k \cdot c_{\text {cat. }}$. [c] Determined at $t=15 \mathrm{~min}$.

sition state of the rate-limiting step of the hydrogenation process in the case of $\mathbf{4 a}$ (see below). The hydrogenation of substrate $\mathbf{S 5}$ (best results shown in Table 6) proceeded more slowly than that of the other substrates; incomplete conver-

Table 6. Selected results of the screening of the PhthalaPhos library in the enantioselective hydrogenation of methyl (E)-2-(acetamidomethyl)-3phenylacrylate (S5). ${ }^{[\mathrm{a}]}$

$$
\int_{\mathrm{Ph}}^{\mathrm{NHAc}} \mathrm{CoOMe} \underset{\mathrm{DCM}, \mathrm{RT}, 2 \mathrm{~h}}{\stackrel{\mathrm{H}_{2}(50 \mathrm{bar}),}{\left[\mathrm{Rh}(\mathrm{cod})_{2} \mathrm{BF}_{4}\right] / \mathrm{L}}} \underbrace{\mathrm{NHAc}}_{\mathrm{Ph}} \mathrm{COOMe}
$$

\begin{tabular}{lccc}
\hline Entry & Ligand & Conv. $[\%]^{[\mathrm{b}]}$ & $e e[\%]^{[\mathrm{b}]}\left([\alpha]_{\mathrm{D}} \operatorname{sign}\right)^{[\mathrm{c}]}$ \\
\hline 1 & $\mathbf{4 a}$ & 96 & $64(+)$ \\
2 & $\mathbf{4 b}$ & 98 & $62(+)$ \\
3 & $\mathbf{4 c}$ & 75 & $91(+)$ \\
4 & $\mathbf{4 g}$ & 73 & $74(+)$ \\
5 & $\mathbf{4 i}$ & 100 & $99(+)$ \\
6 & $\mathbf{5 a}$ & 6 & $32(+)$ \\
7 & $\mathbf{5 b}$ & 37 & $90(+)$ \\
\hline
\end{tabular}

[a] Reaction conditions: substrate/ligand $/\left[\mathrm{Rh}(\operatorname{cod}){ }_{2} \mathrm{BF}_{4}\right]=100: 2.2: 1$, solvent $=\mathrm{CH}_{2} \mathrm{Cl}_{2}, c_{0}(\mathbf{S 5})=0.024 \mathrm{M}, T=25^{\circ} \mathrm{C}, P=50$ bar. [b] Determined by GC analysis with a chiral capillary column (MEGADEX DACTBS $\beta$, diacetyl-tert-butylsilyl- $\beta$-cyclodextrin). [c] Correlation of the $[\alpha]_{D}$ sign with absolute configuration has still not been established.

sion was observed in most cases, even under very high hydrogen pressures (50 bar). However, ligand $4 \mathbf{i}$ gave full conversion and almost complete stereocontrol (Table 6, entry 5), which is the highest ee value reported so far for this substrate (for which only one other highly stereoselective ligand has been reported $\left.{ }^{[16 q]}\right)$. Interestingly, phosphite 4b, which only differed from ligand $4 \mathbf{i}$ in the ancillary amide group (4-( $n$-butyl)anilide instead of a 3,5-bis(trifluoromethyl)anilide; Scheme 2), was remarkably less stereoselective (Table 6, entry 2), which further demonstrates how strongly the diamide group can influence the reaction. The rhodium complexes of both of the reference phosphites were poorly active with substrate S5. As observed with substrate $\mathbf{S 4}$, reference ligand $\mathbf{5 b}$ gave much-higher stereocontrol than 5a (Table 6, entry 7 vs. entry 6). However, the ee value and conversion remained lower than those obtained with the best PhthtalaPhos ligand 4i (Table 6, entry 5), once again confirming the importance of the diamide group. The full set of results from the catalytic screening of substrates S1-S5 is represented graphically in Figure 1. From this summary, the following observations can be drawn:
- For all substrates, the use of PhthalaPhos ligands led to a remarkable improvement in activity and stereocontrol compared to simple monodentate phosphite 5a. This trend was also observed when reference phosphite $\mathbf{5 b}$ was used as a standard, although in one case this ligand gave the same ee value as the best PhthalaPhos ligand.

- There are a relatively large number of highly effective ligands for the hydrogenation of benchmark substrates (S1-S3), whilst only one or two hits were found for challenging olefins (S4 and S5).

- The best-performing ligands were not the same for all substrates, which underlines the value of the library approach in ligand synthesis. Each structural component of these new modular ligands appears to affect their catalytic behavior. In particular, a strong influence is exerted by 1) the size and geometry of the linker group and 2) the nature of the ancillary amide group.

- Some ligands behaved poorly in all cases. In particular, 1) the ligands derived from 3,3'-dimethyl-binol (4r and 4s) showed minimal catalytic activity and almost no stereoselectivity; 2) the ligands containing rigid linker groups (4j-4n) showed lower levels of activity and stereoselectivity than the others.

The PhthalaPhos ligand library was also screened in the rhodium-catalyzed hydrogenation of other challenging olefins (Table 7; also see the Supporting Information). However, these results were not as good as those presented above. Low conversions and $e e$ values (up to $36 \%$ ) were obtained with $N$-(3,4-dihydronaphthalen-2-yl)acetamide (S6), whilst (Z)-methyl 3-acetamido-2-phenylacrylate (S7) gave no conversion even under forcing conditions (100 bar hydrogen pressure). $\beta$-Amino acid precursor S8, [(Z)-methyl 3-acetamidobut-2-enoate], gave promising ee values (up to $83 \%$ ),

Table 7. Other hydrogenation substrates screened with PhthalaPhos ligands.

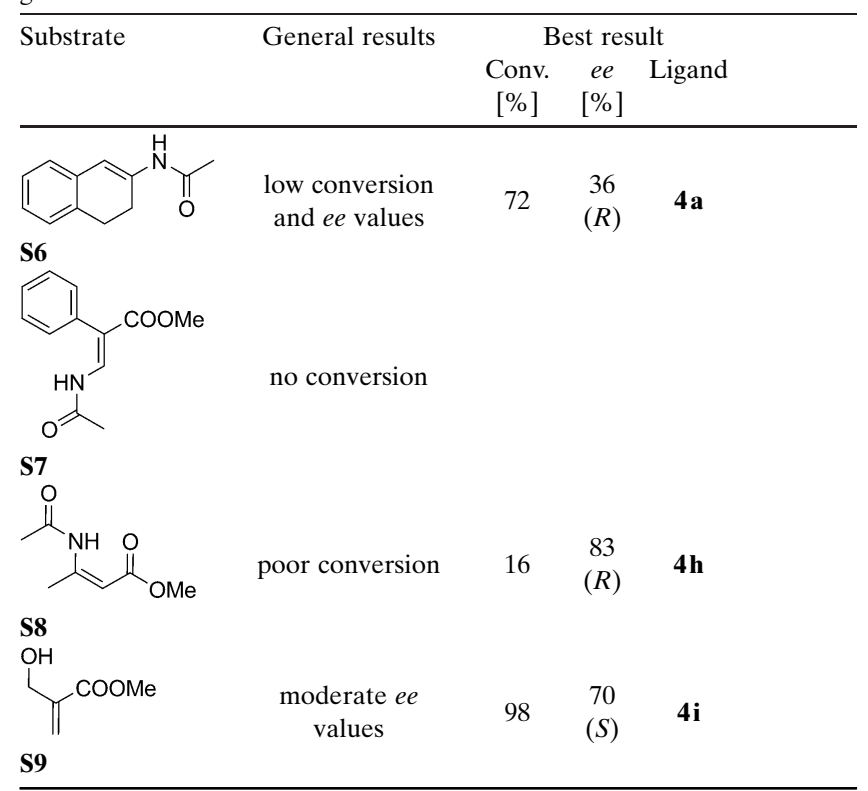


but conversion could not be brought up to acceptable values. The Roche-ester precursor S9, [methyl 2-(hydroxymethyl)acrylate], was hydrogenated with good conversions, but only moderate enantioselectivity (up to $70 \% e e$ ).

Computational studies: We carried out a series of spectroscopic studies on the precatalyst complex $\left[\operatorname{Rh}(\mathbf{4 a})_{2}(\operatorname{cod}) \mathrm{BF}_{4}\right]$ (described in detail in our preliminary communication ${ }^{[22]}$ ). From these studies, the $\mathrm{NH}_{\mathrm{A}}$ protons were found to form intramolecular hydrogen bonds, which is not the case for the free-ligand 4a. A computational study, carried out on the basis of these spectroscopic studies, allowed us to draw a picture of complex $\left[\mathrm{Rh}(\mathbf{4 a})_{2}(\operatorname{cod}) \mathrm{BF}_{4}\right]$ (Figure 3$)$. This study confirmed the formation of a supramolecular bidentate ligand through two interligand hydrogen bonds. ${ }^{[22]}$ The rigidity and pre-organization of the supramolecular ligand was considered to be a possible cause of the superior performance observed for the PhthalaPhos ligands compared to simple monodentate phosphites $5 \mathbf{a}$ and $5 \mathbf{b}$. However, it must be recognized that the square-planar complex [Rh$\left.(\mathbf{4 a})_{2}(\operatorname{cod}) \mathrm{BF}_{4}\right]$ is only a precatalyst, from which the actual catalyst is generated by hydrogenation (and dissociation) of the cyclooctadiene ligand. Moreover, it is widely accepted ${ }^{[32]}$ that the hydrogenation catalytic cycle involves octahedral rhodium complexes, in which the ligand arrangement could significantly differ from that observed in the square-planar precatalyst. In particular, according to the most-recent literature contributions, ${ }^{[32 \mathrm{~h}, \mathrm{i}]}$ the stereoselectivity of the process is likely to be determined during the reversible association of the double bond in the rapidly interconverting dihydrides $\mathbf{A}$
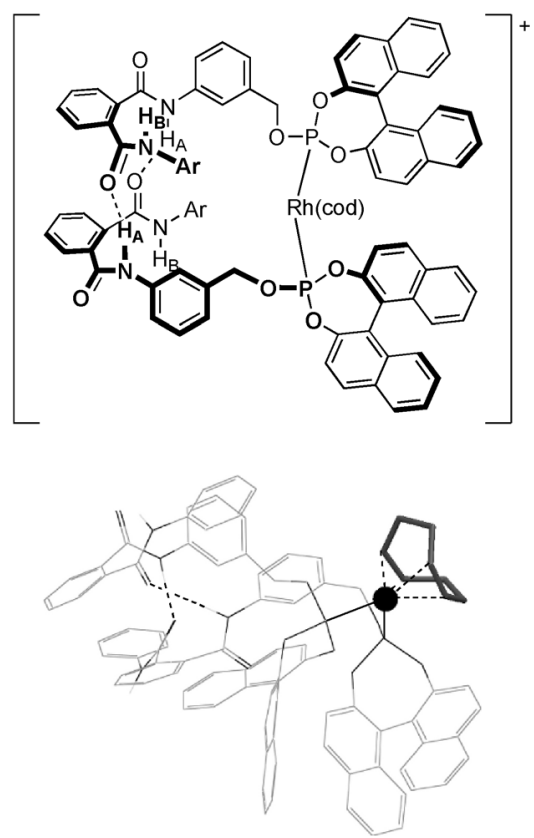

Figure 3. DFT-optimized structure of the precatalyst complex $\left[\operatorname{Rh}(\mathbf{4 a})_{2}\right.$ (cod) $\left.\mathrm{BF}_{4}\right]$. Wires ( $\mathrm{P}$ ligands) and tubes $(\mathrm{cod})$ : $\mathrm{C}=$ gray, amide $\mathrm{H}=$ light gray, heteroatoms $(\mathrm{N}, \mathrm{O}, \mathrm{P})=$ black; $\mathrm{CPK}$ sphere: $\mathrm{Rh}=$ black. For the sake of clarity, all $\mathrm{H}$ atoms bound to carbon are omitted. cod=1,5-cyclooctadiene. and $\mathbf{A}$ ' to give the chelate dihydrides $\mathbf{B}$ and $\mathbf{B}$, respectively (Scheme 6). Consequently, the stereochemical outcome should depend on the face of the substrate that is coordinat-

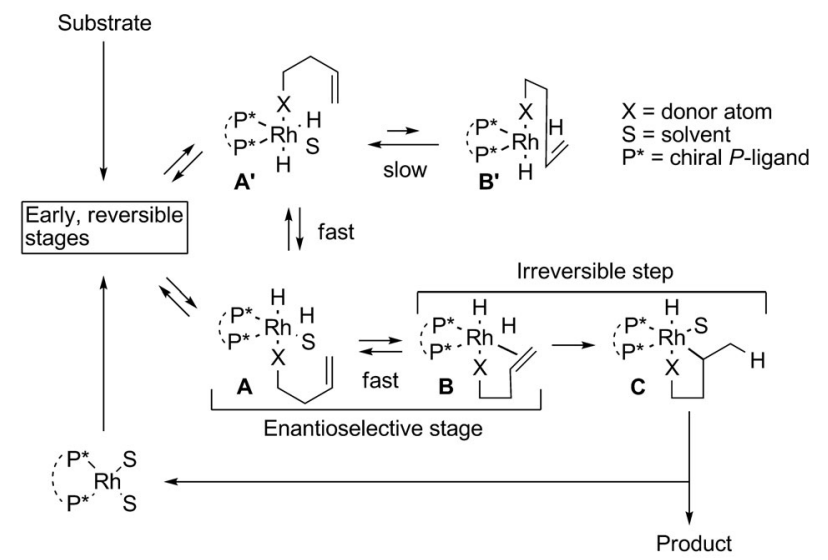

Scheme 6. The stereodiscriminating step of the rhodium-catalyzed hydrogenation according to recent literature contributions. ${ }^{[32 \mathrm{~h}, \mathrm{i}]}$

ed to the rhodium center in the chelate dihydride that has the lowest activation energy (B, Scheme 6). The subsequent fast and irreversible migratory-insertion step fixes the result of the enantioselection forming the monohydride $(\mathbf{C})$ that is then converted into the product. In order to investigate the role of hydrogen-bonding interactions in the part of the reaction coordinate where stereodiscrimination occurs, we decided to build computational models of B-type dihydrides. Of the possible octahedral dihydrides, we considered those that satisfied the following requirements: 1) cis disposition of the phosphite ligands around the rhodium atom, as suggested previously for the catalytic rhodium complexes of monodentate $\mathrm{P}$ ligands, ${ }^{[33]}$ and for the above-discussed structure of the precatalyst complex $\left.\left[\mathrm{Rh}(\mathbf{4 a})_{2}(\operatorname{cod}) \mathrm{BF}_{4}\right] ; 2\right)$ cis disposition of the hydrogen atoms, as a consequence of oxidative addition to the rhodium atom $;^{[32]} 3$ ) coordination of the carbonyl oxygen atom trans to a hydride hydrogen atom, as suggested by experimental evidence reported in the literature. ${ }^{[3 f, i]}$ Therefore, we focused our attention on dihydrides $s i-6 \mathbf{b}$ and si-7b (Scheme 7), which led to the major enantiomer observed experimentally ( $R$, corresponding to coordination on the si face) from the hydrogenation of substrate $\mathbf{S 4}$ promoted by the rhodium complex of ligand $\mathbf{4 a}(96 \% e e) .^{[34]}$

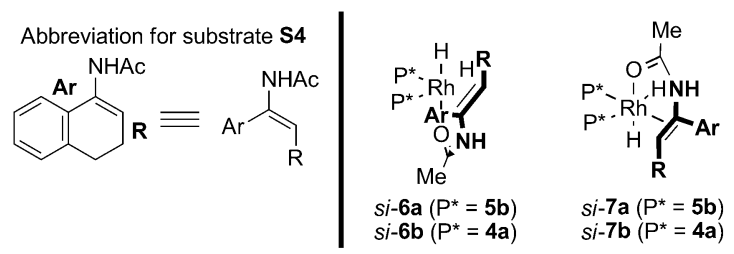

Scheme 7. Pro- $(R)$, B-type chelate dihydride complexes ( $s i$ face of the substrate coordinated to rhodium) studied by MC/MM and DFT calculations. 
The computational workflow used was identical to that adopted for calculating the structure of complex $\left[\mathrm{Rh}(\mathbf{4 a})_{2^{-}}\right.$ (cod) $\left.\mathrm{BF}_{4}\right]$ (Figure 3): ${ }^{[22]} 1$ ) a preliminary DFT optimization (B3LYP/LACVP level of theory ${ }^{[35]}$ was carried out on dihydrides si-6a and si-7a (bearing monodentate phosphite $\mathbf{5 b}$ as ligand $\mathrm{P}^{*}$, see Scheme 7);2) the diamide groups were introduced onto the ligands ( $\mathrm{P}^{*}=\mathbf{4 a}$ without $n$-butyl group), and Monte Carlo/energy-minimization conformational searches $^{[36,37]}$ were performed $\left(\mathrm{AMBER}^{*}, \mathrm{CHCl}_{3} \mathrm{~GB} /\right.$ $\mathrm{SA}){ }^{[38]}$ keeping the geometries of the pre-optimized octahedral core (si-6a and si-7a) frozen, and leaving the diamide groups free to move; 3 ) the si-6b and si-7b global minimum geometries of $\mathrm{MC} / \mathrm{MM}$ searches were optimized at the DFT B3LYP/LACVP level of theory. ${ }^{[35]}$ Quite unexpectedly, no structures featuring ligand-ligand hydrogen bonds were found in the MC/MM conformational search; the octahedral geometry and the presence of the coordinated substrate were incompatible with the ligand arrangement found in the precatalyst complex. Rather, ligand-substrate hydrogenbonding interactions were identified; the global minimum (MC/MM) of si-7b featured a hydrogen bond between the carbonyl oxygen of the $\mathbf{4 a}$ ancillary amide group and the $\mathrm{NH}$ proton of the substrate, whilst the global minimum of si-6b had a distorted hydrogen bond between the same groups. In each of the DFT-optimized structures (shown in Figure 4) a hydrogen bond between the carbonyl oxygen of the ancillary amide group of $\mathbf{4 a}$ and the $\mathrm{NH}$ of the substrate was present, and $s i-7 \mathbf{b}$ was $14.8 \mathrm{kcal} \mathrm{mol}^{-1}$ more stable than si-6b. ${ }^{[34]}$ Therefore, these computational studies suggest that the role of the diamide group of the PhthalaPhos ligands is in binding and orientating the substrate relative to the catalytic metal center, in a "metalloenzyme-like" fashion. The behavior of the supramolecular bidentate ligand, observed in the precatalyst $\left[\mathrm{Rh}(\mathbf{4 a})_{2}(\mathrm{cod}) \mathrm{BF}_{4}\right]$, did not appear to be retained in the octahedral intermediates of the catalytic cycle, which are closer to the stereodefining step of the reaction. Because all of the substrates tested possess a NH hydrogen-bond-donor group, this scenario is fully consistent with the superior enantioselectivity and activity of the PhthalaPhos ligands compared to reference phosphites $\mathbf{5 a}$ and $\mathbf{5 b}$. Unfortunately, this hypothesis cannot be confirmed directly by spectroscopic methods, because it involves very short-lived intermediates of the catalytic cycle. Therefore, we decided to seek indirect evidence of ligandsubstrate interactions by carrying out a series of control experiments as described below.

Control experiments: In order to confirm the role of ligandsubstrate hydrogen-bonding interactions suggested by the computational studies, we decided to carry out a series of control experiments in the hydrogenation of challenging substrates S4 and S5, in which single experimental parameters were modified in turn. First, we investigated the catalytic behavior of ligand $\mathbf{4 a - M e}$, a bis-N-methylated version of ligand $4 \mathbf{a}$ that was readily prepared from the alcohol $\mathbf{3 a}$ as shown in Scheme 8. This ligand, which lacks hydrogen-bonddonor NH groups, is unable to form a corresponding supramolecular bidentate ligand, but still possesses the Lewisbasic amide oxygen atoms required for substrate coordination according to the computational models, si-6b and si-7b, as discussed above. For this reason, a similar level of catalyt-
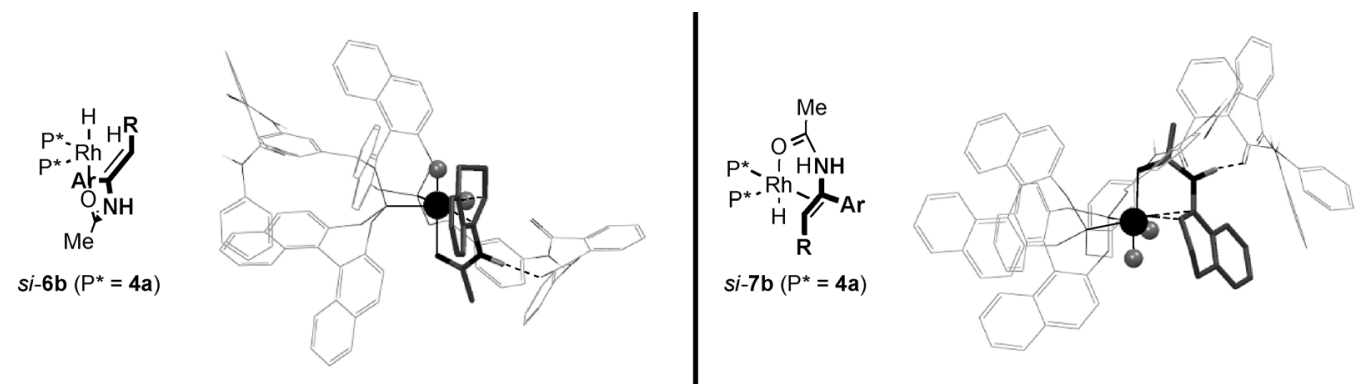

Figure 4. DFT-optimized structures of dihydrides si-6b and si-7 b. Wires (P ligands) and tubes (substrate $\mathbf{S 4}$ ): $\mathrm{C}=$ gray, amide $\mathrm{H}=$ light gray, heteroatoms $(\mathrm{N}, \mathrm{O}, \mathrm{P})=$ black; $\mathrm{CPK}$ spheres: $\mathrm{Rh}=$ black, gray $=\mathrm{H}$. For the sake of clarity, all $\mathrm{H}$ atoms bound to carbon are omitted. 
ic performance by ligands $4 \mathbf{a}$ and $\mathbf{4 a - M e}$ could be taken as indirect proof of substrate-orientation effects. Conversely, poorer catalytic behavior (compared to ligand $\mathbf{4 a}$ ), should be expected from ligand $\mathbf{4 a - M e}$ if ligand-ligand interactions were the main cause of the outstanding performance of the PhthalaPhos ligands. Our results (Table 8) seem to substanti-

Table 8. Use of bis-N-methylated ligand $\mathbf{4 a - M e}$ in the enantioselective hydrogenation of $N$-(3,4-dihydronaphthalen-1-yl)acetamide (S4) and methyl $(E)-2$-(acetamidomethyl)-3-phenylacrylate $(\mathbf{S 5}){ }^{[\mathrm{a}]}$

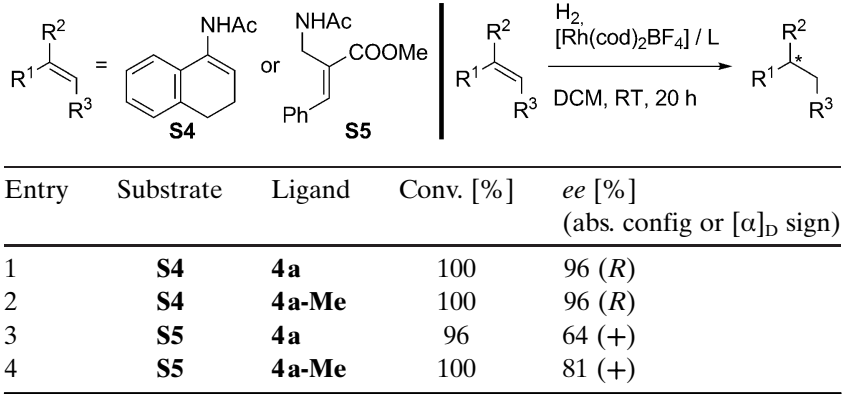

[a] For substrate S4, see the footnotes of Table 4; for substrate $\mathbf{S 5}$, see the footnotes of Table 6 .

ate the hypothesis that a key role is played by ligand-substrate interactions. Indeed, in the hydrogenation of enamide S4, ligand $4 \mathbf{a}-\mathbf{M e}$ gave exactly the same result as ligand $\mathbf{4 a}$ in terms of conversion and stereocontrol (Table 8, entry 2 vs. entry 1). Kinetic studies were carried out under the same conditions as for the hydrogenation of $\mathbf{S 4}$ promoted by the rhodium complexes of ligands $\mathbf{4 a}$ and $\mathbf{5 b}$ (see above). The rhodium complex of ligand $\mathbf{4 a - M e}\left(k_{\text {app }}=0.0259 \mathrm{~min}^{-1}, k=\right.$ $7.81 \mathrm{~L} \mathrm{~mol}^{-1} \mathrm{~min}^{-1}$ ) was slower than the comparable reaction with the rhodium complex of $\mathbf{4 a}$, and of similar activity compared to the complex of $\mathbf{5 b}$ (see Table 5). Thus, the tertiary amide groups of ligand $\mathbf{4} \mathbf{a}-\mathbf{M e}$ did not display the same accelerating effect as the secondary amide groups of $\mathbf{4 a}$, which is likely to be due to different stereoelectronic features. Remarkably, in the hydrogenation of substrate S5, ligand 4a-Me afforded superior enantioselectivity to ligand 4 a (Table 8 , entry 4 vs. entry 3 ). This result suggests that the two carbonyl oxygen atoms of substrate $\mathbf{S 5}$ are not involved in hydrogen-bonding interactions with the ligand (such interactions are not possible for ligand $\mathbf{4 a - M e )}$ ). Rather, the $\mathrm{NH}$ group of substrate $\mathbf{S 5}$ is likely to interact with a carbonyl oxygen atom on the ligand; this interaction is consistent with the scenario depicted for substrate $\mathbf{S 4}$ by the computational studies (see above). We developed computational models of dihydride intermediates si-6c and si-7 c (Figure 5) that would lead to the experimentally determined major enantiomer in the hydrogenation of substrate $\mathbf{S} \mathbf{4}$ promoted by the rhodium complex of ligand $\mathbf{4 a - M e ~}(R$, corresponding to coordination on the si face); these models were created following the same computational methods described for si$\mathbf{6 b}$ and $s i-7 \mathbf{b}$ (see above). The DFT-optimized geometries of dihydride intermediates si-6c and si-7 c featured a single hydrogen bond between the carbonyl oxygen atom of the ancillary amide and the $\mathrm{NH}$ group of the substrate, consistent with the experimental results. Dihydride si-7c was more stable than si-6c by $6.09 \mathrm{kcal} \mathrm{mol}^{-1}$. Hydrogen-bonding interactions between dissolved molecules are expected to become weaker with increasing solvent polarity, with protic solvents displaying the strongest disrupting effect. Although ligand-ligand hydrogen bonds have been detected in even protic solvents in a few cases, ${ }^{[16 i, 39]}$ in general a negative effect of solvent polarity on catalytic performance is interpreted as a sign of the important role played by hydrogenbonding interactions in supramolecular ligands. ${ }^{[15 a, 16 a, b, l]}$ Unfortunately, high enantioselectivities have only been reported for the hydrogenation of prochiral olefins with chiral monophosphite-rhodium complexes in dichloromethane and 1,2-dichloroethane, whilst more-polar or protic solvents cause a dramatic drop in enantiomeric excess. ${ }^{[40]}$ Accordingly, we have experimentally confirmed that the PhthalaPhos ligands as well as the reference phosphites $\mathbf{5 a}$ and $\mathbf{5 b}$ (devoid of the binding motif) behave poorly (i.e. with very low enantioselectivity) in polar or protic solvents (e.g. EtOAc, THF, $i \mathrm{PrOH})$. However, we found an interesting exception: in 2,2,2-trifluoroethanol, benzyl phosphite $\mathbf{5} \mathbf{b}$ maintained its high performance practically unaltered with both substrates S4 and S5 (Table 9, cf. entries 1, 2, 7, 8). Fluorinated alcohols, which are highly polar solvents but poor hydrogen-bond acceptors, have been reported to not disturb the hydrogen bonds of self-assembling rhodium-phosphine

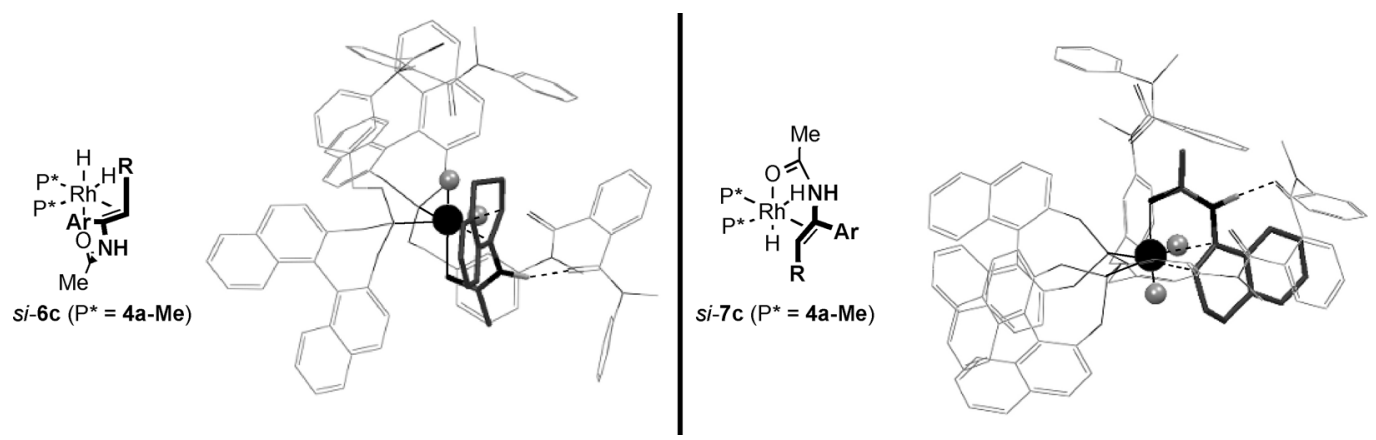

Figure 5. DFT-optimized structures of dihydrides si-6c and si-7 c. Wires (P ligands) and tubes (substrate $\mathbf{S 4}$ ): $\mathrm{C}=$ gray, amide $\mathrm{H}=$ light gray, heteroatoms $(\mathrm{N}, \mathrm{O}, \mathrm{P})=$ black; $\mathrm{CPK}$ spheres: $\mathrm{Rh}=$ black, $\mathrm{H}=$ gray. For the sake of clarity, all $\mathrm{H}$ atoms bound to carbon are omitted. 
Table 9. Solvent screen in the hydrogenation of substrates $\mathbf{S 4}$ and $\mathbf{S 5}$ with ligands $\mathbf{4 a}$, $4 \mathbf{i}, 4 \mathbf{a}-\mathrm{Me}$, and $\mathbf{5 b}{ }^{[\mathrm{a}]}$

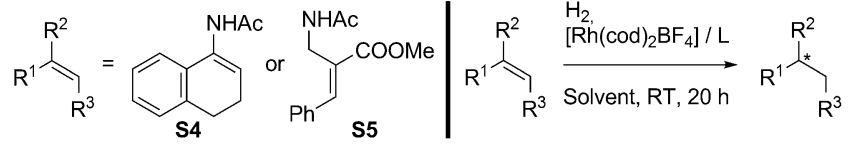

\begin{tabular}{|c|c|c|c|c|c|}
\hline Entry & Substrate & Ligand & Solvent & Conv. $[\%]$ & $\begin{array}{l}e e[\%] \text { (abs. config } \\
\text { or }[\alpha]_{D} \text { sign) }\end{array}$ \\
\hline 1 & S4 & $5 \mathbf{b}$ & $\mathrm{CH}_{2} \mathrm{Cl}_{2}$ & 100 & $96(R)$ \\
\hline 2 & S4 & 5b & $\mathrm{CF}_{3} \mathrm{CH}_{2} \mathrm{OH} / \mathrm{CH}_{2} \mathrm{Cl}_{2}(7: 1)$ & 100 & $93(R)$ \\
\hline 3 & S4 & $4 \mathbf{a}$ & $\mathrm{CH}_{2} \mathrm{Cl}_{2}$ & 100 & $96(R)$ \\
\hline 4 & S4 & $4 a$ & $\mathrm{CF}_{3} \mathrm{CH}_{2} \mathrm{OH} / \mathrm{CH}_{2} \mathrm{Cl}_{2}(7: 1)$ & 100 & $38(R)$ \\
\hline 5 & S4 & 4a-Me & $\mathrm{CH}_{2} \mathrm{Cl}_{2}$ & 100 & $96(R)$ \\
\hline 6 & S4 & $4 \mathrm{a}-\mathrm{Me}$ & $\mathrm{CF}_{3} \mathrm{CH}_{2} \mathrm{OH} / \mathrm{CH}_{2} \mathrm{Cl}_{2}(7: 1)$ & 100 & $8(R)$ \\
\hline 7 & S5 & $5 \mathbf{b}$ & $\mathrm{CH}_{2} \mathrm{Cl}_{2}$ & 37 & $90(+)$ \\
\hline 8 & S5 & 5b & $\mathrm{CF}_{3} \mathrm{CH}_{2} \mathrm{OH} / \mathrm{CH}_{2} \mathrm{Cl}_{2}(7: 1)$ & 45 & $93(+)$ \\
\hline 9 & S5 & $4 i$ & $\mathrm{CH}_{2} \mathrm{Cl}_{2}$ & 100 & $99(+)$ \\
\hline 10 & S5 & $4 i$ & $\mathrm{CF}_{3} \mathrm{CH}_{2} \mathrm{OH} / \mathrm{CH}_{2} \mathrm{Cl}_{2}(7: 1)$ & 95 & $47(+)$ \\
\hline 11 & S5 & 4a-Me & $\mathrm{CH}_{2} \mathrm{Cl}_{2}$ & 100 & $81(+)$ \\
\hline 12 & S5 & $4 \mathrm{a}-\mathrm{Me}$ & $\mathrm{CF}_{3} \mathrm{CH}_{2} \mathrm{OH} / \mathrm{CH}_{2} \mathrm{Cl}_{2}(7: 1)$ & 100 & $4(+)$ \\
\hline
\end{tabular}

[a] For substrate S4, see the footnotes of Table 4; for substrate S5, see the footnotes of Table 6.

complexes. ${ }^{[39]}$ In the case of the phthalamide-functionalized phosphites 4a, 4i, and 4a-Me, 2,2,2-trifluoroethanol caused a substantial drop in enantiomeric excess (Table 9, cf. entries 3-6, 9-12), presumably by disrupting either the ligandligand or ligand-substrate hydrogen bonds. In particular, the observation of a strong solvent effect in the case of ligand 4a-Me (Table 9, cf. entries 5, 6, and 11, 12) lends support to the computational studies regarding the crucial role of ligand-substrate hydrogen-bonding interactions. In order to substantiate our interpretation of the observed catalytic behavior, we decided to carry out experiments on analogues of substrates S4 and S5 that contained no hydrogen-bonddonor atoms. The N-methylated analogues S4-Me and S5Me were synthesized by methylation of compounds $\mathbf{S 4}$ and S5 (Scheme 9A), whilst their corresponding esters, S4-0 ${ }^{[41]}$ and $\mathbf{S 5 - \mathbf { O } ^ { [ 4 2 ] }}$ (Scheme $9 \mathrm{~B}$ ), were prepared according to literature procedures. For each series of analogues (Table 10 and Table 11, respectively), the rhodium complexes of $\mathbf{4 a - M e}$ and of the best-performing PhthalaPhos ligand with the parent olefin were investigated. Although the modifications introduced on the substrates may have affected their stereoelectronic properties far beyond the simple loss of hydrogen-bond-donor ability, we believe that these experiments could be useful in evaluating our hypotheses on ligand-substrate interactions. The results of the screen of nonhydrogen-bond-donor analogues of substrate $\mathbf{S 4}$ are shown in Table 10. Remarkably, both ligand $\mathbf{4 a}$ and 4a-Me gave significantly lower conversion and ee values with the $\mathrm{N}$-methylated substrate (S4-Me) than with substrate $\mathbf{S 4}$ (Table 10, entries 3 and 4 vs. entries 1 and 2). This result is due the lack of an NH proton in substrate S4-Me, which is then unable to interact with the ligand's amide oxygen. Consistently very low conversion (if any) was observed in the hydrogenation of enol ester S4-O, even under 100 bar hydrogen pressure (Table 10, entries 5-8). However, this result can also be explained by the different stereoelectronic properties of enol esters and enamides. The hypothesized role of ligand-substrate hydrogen-bonding interactions is also consistent with the results obtained with substrate $\mathbf{S 5}$ and its non-hydrogen-bond-donor analogues S5-Me and S5-O (Table 11). With both ligands $\mathbf{4 i}$ and $\mathbf{4 a - M e , ~ s u b s t r a t e ~ S 5 - ~}$ Me was converted into the product in low yields (Table 11, entries 4 and 5). The dramatic drop in conversion observed (compared to substrate S5, entries 1 and 2) supports the postulated key role of hydrogen-bonding interactions between the NH atom of substrate $\mathbf{S 5}$ and the amide oxygen atom of the catalyst. It appears that the stereoselectivity of the hydrogenation with N-methylated substrate S5-Me is relatively high, irrespective of the ligand used (Table 11, entries 4-6). Even the poorly performing ligand $\mathbf{5 a}$, which is devoid of hydrogen-bonding functionalities, gave a muchhigher ee value with substrate S5-Me compared to S5 (Table 11, entry 6 vs. entry 3 ). None of the ligands tested afforded the conversion of enol ester S5-O, even under 100 bar hydrogen pressure (Table 11, entries 7-10). This latter result is of particular interest if one considers that, unlike S4-O, substrate S5-O is not an enol ester and thusapart from the lack of hydrogen-bond-donor ability-the stereoelectronic properties of its double bond should quiteclosely resemble those of substrate S5. Taken together, these control experiments confirm that hydrogen bonding has a strong influence on the catalytic properties of the PhthalaPhos ligands, and are consistent with the results of the computational studies on an intermediate that
Scheme 9. A) Synthesis of the N-methylated substrates S4-Me and S5-Me. B) Enol ester substrates S4-O ${ }^{[41}$ and S5-O. ${ }^{[42]}$
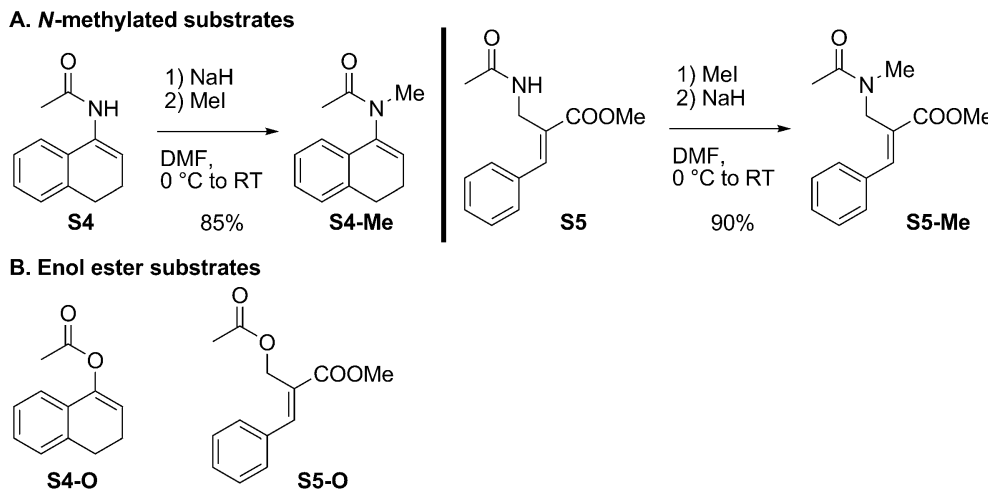
Table 10. Hydrogenation of substrate $\mathbf{S 4}$ and its analogues (S4-Me and S4-0) using ligands $4 \mathbf{a}$ and $4 \mathbf{a}-\mathbf{M e}^{[\mathrm{a}]}$

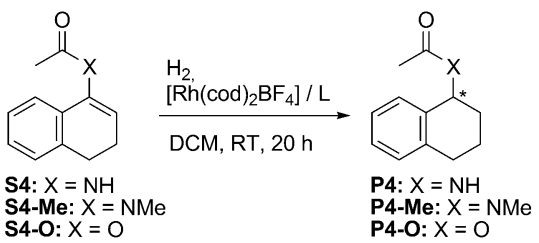

Entry Substrate Ligand $P[\mathrm{bar}] \quad$ Conv. [\%] $\quad e e[\%]$ (abs. config

\begin{tabular}{lllrrl} 
& & & & & or $[\alpha]_{\mathrm{D}}$ sign $)$ \\
\hline 1 & $\mathbf{S 4}^{[\mathrm{b}]}$ & $\mathbf{4 a}$ & 12 & 100 & $96(R)$ \\
2 & $\mathbf{S 4}^{[\mathrm{b}]}$ & $\mathbf{4 a - M e}$ & 12 & 100 & $96(R)$ \\
3 & $\mathbf{S 4 - M e}^{[\mathrm{c}]}$ & $\mathbf{4 a}$ & 12 & 72 & $87(+)$ \\
4 & $\mathbf{S 4 - M e}^{[\mathrm{c}]}$ & $\mathbf{4 a - M e}$ & 12 & 62 & $87(+)$ \\
5 & $\mathbf{S 4 - O}^{[\mathrm{d}]}$ & $\mathbf{4 a}$ & 12 & 0 & - \\
6 & $\mathbf{S 4 - O}^{[\mathrm{d}]}$ & $\mathbf{4 a}$ & 100 & 3 & n.d. \\
7 & $\mathbf{S 4 - O}^{[\mathrm{d}]}$ & $\mathbf{4 a - M e}$ & 12 & 0 & - \\
8 & $\mathbf{S 4 - O}^{[\mathrm{d}]}$ & $\mathbf{4 a - M e}$ & 100 & 2 & n.d. \\
\hline
\end{tabular}

[a] Reaction conditions: substrate/ligand/[Rh( $\left.\operatorname{cod})_{2} \mathrm{BF}_{4}\right]=100: 2.2: 1$, solvent $=\mathrm{CH}_{2} \mathrm{Cl}_{2}, c_{0}$ (substrate) $=0.024 \mathrm{M}, T=25^{\circ} \mathrm{C}$. [b] Conversion and $e e$ determined as specified in the footnotes of Table 4. [c] Conversion and $e e$ determined by GC analysis with a chiral capillary column (MEGADEX DACTBS $\beta$, diacetyl-tert-butylsilyl- $\beta$-cyclodextrin); correlation of $[\alpha]_{\mathrm{D}}$ sign with absolute configuration has still not been established. [d] Conversion determined by ${ }^{1} \mathrm{H}$ NMR spectroscopic analysis of the crude reaction mixture; ee determined by HPLC equipped with a chiral column (Phenomenex Lux Cellulose 3).

Table 11. Hydrogenation of substrate $\mathbf{S 5}$ and its analogues (S5-Me and S5-O) using ligands $4 \mathbf{i}$ and $\mathbf{4 a - M e} .^{[a]}$

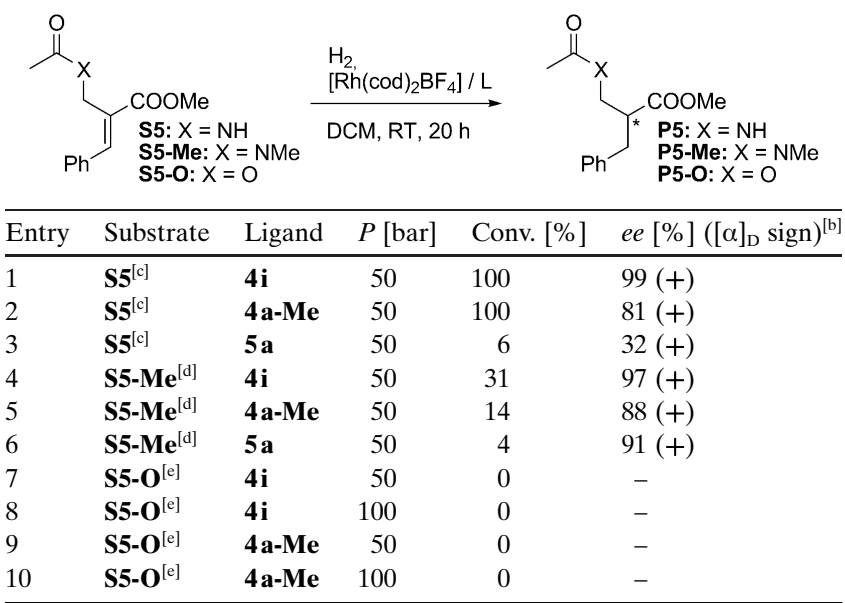

[a] Reaction conditions: substrate/ligand/[Rh( $\left.(\operatorname{cod})_{2} \mathrm{BF}_{4}\right]=100: 2.2: 1$, solvent $=\mathrm{CH}_{2} \mathrm{Cl}_{2}, c_{0}$ (substrate) $=0.024 \mathrm{M}, T=25^{\circ} \mathrm{C}$. [b] Correlation of $[\alpha]_{\mathrm{D}}$ sign with absolute configuration has still not been established. [c] Conversion and ee determined as specified in the footnotes of Table 6. [d] Conversion determined by ${ }^{1} \mathrm{H}$ NMR spectroscopic analysis on the crude reaction mixture; ee determined by HPLC equipped with a chiral column (Phenomenex Lux Cellulose 2). [e] Conversion determined by ${ }^{1} \mathrm{H}$ NMR spectroscopic analysis on the crude reaction mixture; ee determined by HPLC equipped with a chiral column (Daicel Chiralcel OD-H)

forms very close to the stereodiscriminating step of the hydrogenation process. Accordingly, the substrate orientation achieved by the formation of a hydrogen bond between its $\mathrm{NH}$ group and the ancillary amide oxygen of a ligand is rele- vant for the outstanding catalytic performances of the PhthalaPhos ligands.

\section{Conclusions}

A library of 19 chiral binol-monophosphite ligand that contain a phthalic acid secondary bis-amide group has been synthesized and screened in the rhodium-catalyzed hydrogenation of several prochiral dehydroamino esters and enamides. An outstanding level of stereocontrol has been achieved with three benchmark alkenes and two industrially relevant olefins that are commonly considered as challenging hydrogenation substrates. The role of the diamide group has been investigated by means of spectroscopic and computational studies on both a precatalyst complex and an intermediate in the hydrogenation catalytic cycle that is formed close to the stereodiscriminating step. As demonstrated for ligand 4a, interligand hydrogen-bonding interactions are likely to be present in all of the PhthalaPhos square-planar precatalyst rhodium complexes, and thus the ligands behave as "supramolecular bidentate ligands". However, as suggested by both computational and experimental evidence, the formation of a hydrogen bond between the amide oxygen atom of the ligand and the amide $\mathrm{NH}$ of the substrate may take place in the octahedral intermediates of the catalytic cycle and thus be responsible for substrate orientation during the hydrogenation process. The reversible and dynamic nature of hydrogen bonding is thus consistent with a scenario where the ligand-ligand interactions present in the precatalyst may break during the catalytic cycle (after dissociation of the cod ligand), and ligand-substrate interactions may take place instead, thereby possibly accounting for the faster rate of reaction and higher enantioselectivities observed.

\section{Experimental Section}

General remarks: All reactions were carried out in flame-dried glassware with magnetic stirring under a nitrogen atmosphere unless otherwise stated. The solvents were distilled over the following drying agents (given in parentheses) and transferred under nitrogen: $\mathrm{CH}_{2} \mathrm{Cl}_{2}\left(\mathrm{CaH}_{2}\right), \mathrm{MeOH}$ $\left(\mathrm{CaH}_{2}\right)$, THF (Na), 1,4-dioxane $(\mathrm{Na}), \mathrm{Et}_{3} \mathrm{~N}\left(\mathrm{CaH}_{2}\right)$. Dry $\mathrm{Et}_{2} \mathrm{O}$ and $\mathrm{CHCl}_{3}$ (molecular sieves in bottles with crown cap) were purchased from Fluka and stored under nitrogen. The reactions were monitored by analytical thin-layer chromatography (TLC) using silica gel $60 \mathrm{~F}_{254}$ pre-coated glass plates $(0.25 \mathrm{~mm}$ thickness). Visualization was accomplished by irradiation with a UV lamp and/or staining with alkaline potassium permanganate solution. Flash chromatography was performed on silica gel (60 A, particle size $40-64 \mu \mathrm{m}$ ) as the stationary phase, following the procedure by Still et al. ${ }^{[43]}$ Proton NMR spectra were recorded on a spectrometer operating at $400.13 \mathrm{MHz}$. Proton chemical shifts are reported in ppm $(\delta)$ with residual solvent referenced relative to tetramethylsilane (TMS) as the internal standard $\left(\mathrm{CDCl}_{3}, \delta=7.26 \mathrm{ppm} ; \mathrm{CD}_{2} \mathrm{Cl}_{2}, \delta=5.32 \mathrm{ppm}\right.$; [ $\left.\mathrm{D}_{6}\right] \mathrm{DMSO}$, $\left.\delta=2.50 \mathrm{ppm} ; \mathrm{CD}_{3} \mathrm{OD}, \delta=3.33 \mathrm{ppm}\right)$. The following abbreviations are used to describe spin multiplicity: $\mathrm{s}=$ singlet, $\mathrm{d}=$ doublet, $\mathrm{t}=$ triplet, $\mathrm{q}=$ quartet, $\mathrm{m}=$ multiplet, $\mathrm{br}=$ broad signal, $\mathrm{dd}=$ doublet of doublet, $\mathrm{td}=$ triplet of doublets. ${ }^{13} \mathrm{C}$ NMR spectra were recorded on a $400 \mathrm{MHz}$ spectrometer operating at $100.56 \mathrm{MHz}$, with complete proton decoupling. Carbon chemical shifts are reported in ppm $(\delta)$ relative to TMS with the respective solvent resonance as the internal standard $\left(\mathrm{CDCl}_{3}, \delta=\right.$ 
$77.23 \mathrm{ppm} ; \mathrm{CD}_{2} \mathrm{Cl}_{2}, \delta=54.00 \mathrm{ppm} ;[\mathrm{D}]_{6} \mathrm{DMSO}, \delta=39.51 \mathrm{ppm} ; \mathrm{CD}_{3} \mathrm{OD}$, $\delta=49.05 \mathrm{ppm}) .{ }^{31} \mathrm{P}$ NMR spectra were recorded on a $400 \mathrm{MHz}$ spectrometer operating at $162 \mathrm{MHz}$, with complete proton decoupling. ${ }^{31} \mathrm{P}$ NMR spectroscopic chemical shifts are reported in ppm $(\delta)$ relative to external $85 \% \quad \mathrm{H}_{3} \mathrm{PO}_{4}$ at $0 \mathrm{ppm}$ (positive values indicate downfield shifts). ${ }^{19} \mathrm{~F}$ NMR spectra were recorded on a $300 \mathrm{MHz}$ spectrometer operating at $282 \mathrm{MHz} .{ }^{19} \mathrm{~F}$ NMR spectroscopic chemical shifts are reported in ppm $(\delta)$ relative to external $\mathrm{CFCl}_{3}$ at $0 \mathrm{ppm}$ (positive values indicate downfield shifts). The coupling constant values are given in $\mathrm{Hz}$. Infrared spectra were recorded on a standard FT/IR spectrometer. Optical rotation values were measured on an automatic polarimeter with a $1 \mathrm{dm}^{3}$ cell at the sodium D line $(\lambda=589 \mathrm{~nm})$. Gas chromatography was performed on a GC instrument equipped with a flame-ionization detector, using a chiral capillary column. High-resolution mass spectra (HRMS) were performed on a Fourier Transform Ion Cyclotron Resonance (FT-ICR) Mass Spectrometer APEX II \& Xmass software (Bruker Daltonics), 4.7 T Magnet (Magnex) equipped with an ESI source, available at CIGA (Centro Interdipartimentale Grandi Apparecchiature) c/o Università degli Studi di Milano. Low-resolution mass spectra (MS) were acquired either on a Thermo-Finnigan LCQ Advantage mass spectrometer (ESI ion source) or on a VG Autospec M246 spectrometer (FAB ion source). Elemental analyses were performed on a Perkin-Elmer Series II CHNS/O Analyzer 2000.

Materials: Phthalic anhydride sometimes contains large amounts of phthalic acid. In such cases, the mixture can be easily re-converted into the pure anhydride by melting it in an open flask and strongly heating it for $10 \mathrm{~min}$. On cooling to room temperature, pure phthalic anhydride crystallizes as a white solid. Phthalic anhydride was stored in a desiccator. The other commercially available starting materials were used as received. For the synthesis of non-commercially available amino alcohols, see the Supporting Information.

General procedure for the preparation of phthalic acid mono-amides 1 a1c: The amine (1 equiv) was added to a stirring solution of phthalic anhydride ( 1 equiv, $1.44 \mathrm{M}$; typical scale $=15 \mathrm{~g}$ ) in $\mathrm{CHCl}_{3}$; a white precipitate soon began to form. The mixture was heated to reflux and stirred for $3 \mathrm{~h}$, then it was cooled with an ice bath. The precipitate was collected using a Buchner funnel and washed on the frit with $6: 1 \mathrm{CHCl}_{3} / n$-hexane until the red impurities had disappeared. The product was dried under high vacuum.

\section{Preparation of phthalisoimides 2a, b:}

(3-(4-butylphenylimino)isobenzofuran-1(3H)-one) $\mathbf{2 a}:^{[24]}$ Trifluoroacetic anhydride $(2.1 \mathrm{~mL}, 15.13 \mathrm{mmol}, 1.5$ equiv) was added dropwise to a stirring solution of acid $\mathbf{1 a}\left(3 \mathrm{~g}, 10.09 \mathrm{mmol}, 1\right.$ equiv) and $\mathrm{Et}_{3} \mathrm{~N}(4.2 \mathrm{~mL}$, $30.27 \mathrm{mmol}, 3$ equiv) in 1,4-dioxane $(45 \mathrm{~mL})$ that was kept at $0{ }^{\circ} \mathrm{C}$ with an ice bath. After $5 \mathrm{~min}$ the yellow solution was allowed to warm to room temperature and was stirred for $15 \mathrm{~min}$, then it was poured in cold $\mathrm{H}_{2} \mathrm{O}$ $(120 \mathrm{~mL})$. A pale-yellow precipitate formed, which was collected by filtration using a Buchner funnel and washed with $\mathrm{H}_{2} \mathrm{O}$. The product was dried for $20 \mathrm{~min}$ on the filter and then overnight under high vacuum. A pale yellow solid was obtained. Yield: $2.72 \mathrm{~g}$ (97\%); m.p. $58-61{ }^{\circ} \mathrm{C}$; ${ }^{1} \mathrm{H}$ NMR $\left(400 \mathrm{MHz}, \mathrm{CD}_{2} \mathrm{Cl}_{2}\right): \delta=8.11\left(\mathrm{~d},{ }^{3} J(\mathrm{H}, \mathrm{H})=7.6 \mathrm{~Hz}, 1 \mathrm{H}\right), \delta 8.00$ $\left(\mathrm{d},{ }^{3} J(\mathrm{H}, \mathrm{H})=7.6 \mathrm{~Hz}, 1 \mathrm{H}\right), \delta 7.90\left(\mathrm{t},{ }^{3} J(\mathrm{H}, \mathrm{H})=7.6 \mathrm{~Hz}, 1 \mathrm{H}\right), 7.80\left(\mathrm{t},{ }^{3} J-\right.$ $(\mathrm{H}, \mathrm{H})=7.6 \mathrm{~Hz}, 1 \mathrm{H}), 7.41\left(\mathrm{~d},{ }^{3} J(\mathrm{H}, \mathrm{H})=8.2 \mathrm{~Hz}, 2 \mathrm{H}\right), 7.28\left(\mathrm{~d},{ }^{3} J(\mathrm{H}, \mathrm{H})=\right.$ $8.2 \mathrm{~Hz}, 2 \mathrm{H}), 2.69\left(\mathrm{t},{ }^{3} J(\mathrm{H}, \mathrm{H})=7.8 \mathrm{~Hz}, 2 \mathrm{H}\right), 1.68(\mathrm{~m}, 2 \mathrm{H}), 1.43(\mathrm{~m}, 2 \mathrm{H})$, $1.00 \mathrm{ppm}(\mathrm{t}, J(\mathrm{H}, \mathrm{H})=7.4 \mathrm{~Hz}, 3 \mathrm{H}) ;{ }^{13} \mathrm{C} \mathrm{NMR}\left(100 \mathrm{MHz}, \mathrm{CD}_{2} \mathrm{Cl}_{2}\right): \delta=$ $165.5,147.2,142.2,142.1,137.8,136.0,133.6,129.5,128.2,125.7,125.1$, 124.0, 35.8, 34.2, 22.9, $14.3 \mathrm{ppm}$; IR $(\mathrm{KBr}): \tilde{v}=2956.3,2855.1,1791.6$, 1689.3, $915.1 \mathrm{~cm}^{-1}$; MS (ESI+): $m / z 280.3[M+\mathrm{H}]^{+}\left(\right.$calcd for $\mathrm{C}_{18} \mathrm{H}_{18} \mathrm{NO}_{2}$ : 280.1 ) ; elemental analysis calcd (\%) for $\mathrm{C}_{18} \mathrm{H}_{17} \mathrm{NO}_{2}$ : C 77.40, H 6.13, N 5.01; found: C 77.33, H 6.32, N 4.97 .

3-(3,5-Bis(trifluoromethyl)phenylimino)isobenzofuran-1(3H)-one $\quad \mathbf{2 b}$ : Trifluoroacetic anhydride $(0.276 \mathrm{~mL}, 1.988 \mathrm{mmol}, 1.5$ equiv) was added dropwise to a stirring solution of acid $\mathbf{1 b}(0.5 \mathrm{~g}, 1.325 \mathrm{mmol}, 1$ equiv) and $\mathrm{Et}_{3} \mathrm{~N}\left(0.185 \mathrm{~mL}, 1.325 \mathrm{mmol}, 1\right.$ equiv) in THF $(6 \mathrm{~mL}) \mathrm{kept}$ at $0^{\circ} \mathrm{C}$ with an ice bath. After $5 \mathrm{~min}$ the solution was allowed to warm to room temperature and was stirred for $10 \mathrm{~min}$. A second portion of $\mathrm{Et}_{3} \mathrm{~N}(0.37 \mathrm{~mL}$, $3.976 \mathrm{mmol}, 2$ equiv) was added dropwise, and the solution was stirred for $20 \mathrm{~min}$ at room temperature. The volatile compounds were removed under reduced pressure and the product was purified by flash chromatography on silica gel through a short pad of silica $\left(1: 1 n\right.$-hexane $\left./ \mathrm{CH}_{2} \mathrm{Cl}_{2}\right)$. Compound $\mathbf{2 b}$ was obtained as a white solid. Yield: $471 \mathrm{mg}(99 \%)$; m.p $127-129^{\circ} \mathrm{C} ;{ }^{1} \mathrm{H}$ NMR $\left(400 \mathrm{MHz}, \mathrm{CDCl}_{3}\right): \delta=8.15\left(\mathrm{~d},{ }^{3} J(\mathrm{H}, \mathrm{H})=7.6 \mathrm{~Hz}\right.$, $1 \mathrm{H}), 8.06\left(\mathrm{~d},{ }^{3} J(\mathrm{H}, \mathrm{H})=7.6 \mathrm{~Hz}, 1 \mathrm{H}\right), 7.97\left(\mathrm{td},{ }^{3} J(\mathrm{H}, \mathrm{H})=7.6 \mathrm{~Hz},{ }^{4} J(\mathrm{H}, \mathrm{H})=\right.$ $0.9 \mathrm{~Hz}, 1 \mathrm{H}), 7.90\left(\mathrm{td},{ }^{3} J(\mathrm{H}, \mathrm{H})=7.6 \mathrm{~Hz},{ }^{4} J(\mathrm{H}, \mathrm{H})=0.7 \mathrm{~Hz}, 1 \mathrm{H}\right), 7.82(\mathrm{~s}$ $2 \mathrm{H}), 7.80 \mathrm{ppm}(\mathrm{s}, 1 \mathrm{H}) ;{ }^{13} \mathrm{C} \mathrm{NMR}\left(100 \mathrm{MHz}, \mathrm{CDCl}_{3}\right): \delta=164.4,150.7$, $146.5,136.7,136.5,134.7,132.7\left(\mathrm{q},{ }^{2} J(\mathrm{C}, \mathrm{F})=33.5 \mathrm{~Hz}\right), 128.3,126.2,124.5$, $124.5,123.9\left(\mathrm{q},{ }^{1} J(\mathrm{C}, \mathrm{F})=272.2 \mathrm{~Hz}\right), 119.9 \mathrm{ppm}(\mathrm{m}) ;{ }^{19} \mathrm{~F} \mathrm{NMR}(282 \mathrm{MHz}$, $\left.\mathrm{CDCl}_{3}\right): \delta=-62.2 \mathrm{ppm}$; IR (film): $\tilde{v}=3083.6,3042.2,1827.2,1796.4$, $1700.9,1279.5,1118.5 \mathrm{~cm}^{-1}$; MS (FAB+): $\mathrm{m} / z 360.0[M+\mathrm{H}]^{+}$(calcd for $\mathrm{C}_{16} \mathrm{H}_{8} \mathrm{~F}_{6} \mathrm{NO}_{2}$ : 360.0); elemental analysis calcd (\%) for $\mathrm{C}_{16} \mathrm{H}_{7} \mathrm{~F}_{6} \mathrm{NO}_{2}$ C 53.50, H 1.96, N 3.90; found: C 53.35, H 1.88, N 3.90 .

General procedure for the preparation of alcohols $3 \mathrm{a}-\mathrm{l}$ and $3 \mathrm{n}-3 \mathrm{~s}$ : Phthalisoimide $\mathbf{2 a}$ or $\mathbf{2 b}$ ( 1 equiv, typical scale $0.3 \mathrm{~g}$ ) was added to stirring solution of the chosen amino alcohol $(1.2$ equiv, $0.11 \mathrm{M})$ in THF. The mixture was stirred overnight at room temperature. Two alternative workup procedures were followed depending on whether the product precipitated out of solution or not

Workup 1 (soluble product): the mixture was diluted with EtOAc (triple the volume of THF) and washed three times with $1 \mathrm{~m} \mathrm{HCl}$. The organic phase was dried with $\mathrm{Na}_{2} \mathrm{SO}_{4}$ and evaporated. The product was purified by flash chromatography on silica gel.

Workup 2 (insoluble product): the precipitate was collected by filtration using a Buchner funnel and washed on the frit with small volumes of 1:1 $\mathrm{Et}_{2} \mathrm{O} / n$-hexane until the yellow impurities had disappeared. The product obtained from this workup procedure did not need chromatographic purification.

General procedure for the preparation of phosphites $4 \mathrm{a}-4 \mathrm{~s}$ and $4 \mathrm{a}-\mathrm{Me}$ Two alternative, slightly different procedures were followed depending on whether the starting alcohol was soluble in THF or not.

General procedure 1: $(S)$-binol- $\mathrm{PCl}$ or $(R)-3,3^{\prime}$-dimethyl-binol- $\mathrm{PCl}$ (1 equiv, typical scale $=0.3 \mathrm{~g}$ ) was added to a stirring solution of the selected alcohol (1 equiv, $0.1 \mathrm{M}$ ) and $\mathrm{Et}_{3} \mathrm{~N}$ (3 equiv) in THF. The obtained mixture was stirred overnight and then collected by filtration through a pad of Celite (washing with THF). The solvent was evaporated under reduced pressure and the crude product was purified by flash chromatography on silica gel.

General procedure 2: $(S)$-Binol-PCl $(1$ equiv, typical scale $=0.3 \mathrm{~g}$ ) was added to a stirring suspension of the selected alcohol (1 equiv) and $\mathrm{Et}_{3} \mathrm{~N}$ (3 equiv) in $6: 4 \mathrm{THF} / \mathrm{CH}_{2} \mathrm{Cl}_{2}$ (ca. $0.1 \mathrm{M}$ ). The obtained mixture was stirred overnight and then $\mathrm{Et}_{2} \mathrm{O}$ (half of the volume of the $\mathrm{THF} / \mathrm{CH}_{2} \mathrm{Cl}_{2}$ mixture) was added. The mixture was collected by filtration through a pad of Celite (washing with THF), then the solvent was evaporated under reduced pressure and the crude product was purified by flash chromatography on silica gel.

$N^{1}$-(4-Butylphenyl)- $N^{2}$-(3-(((11 bS)-dinaphtho[2,1- $\left.d: 1^{\prime}, 2^{\prime}-f\right][1,3,2]$ dioxaphosphepin-4-yloxy)methyl)phenyl)phthalamide $4 \mathbf{a}$ : The product was prepared according to general procedure 1 starting from $(S)$-binol-PCl $(0.314 \mathrm{~g})$ and alcohol $\mathbf{3 a}(0.36 \mathrm{~g})$ in the presence of $\mathrm{Et}_{3} \mathrm{~N}(0.375 \mathrm{~mL}) . \mathrm{Pu}-$ rification by flash chromatography on silica gel $\left(\mathrm{CH}_{2} \mathrm{Cl}_{2}\right.$ and then 95:5 $\left.\mathrm{CH}_{2} \mathrm{Cl}_{2} / \mathrm{Et}_{2} \mathrm{O}\right)$ gave the product as a white solid. Yield: $0.473 \mathrm{~g}(74 \%)$; m.p. $114-121^{\circ} \mathrm{C} ;[\alpha]_{\mathrm{D}}^{19}=+277.6\left(c=1.0\right.$ in $\left.\mathrm{CH}_{2} \mathrm{Cl}_{2}\right) ;{ }^{1} \mathrm{H}$ NMR $(400 \mathrm{MHz}$, $\left.\mathrm{CD}_{2} \mathrm{Cl}_{2}\right): \delta=9.40(\mathrm{~s}, 1 \mathrm{H}), 9.02(\mathrm{~s}, 1 \mathrm{H}), 8.04\left(\mathrm{~d},{ }^{3} J(\mathrm{H}, \mathrm{H})=8.8 \mathrm{~Hz}, 1 \mathrm{H}\right)$, $8.00\left(\mathrm{~d},{ }^{3} J(\mathrm{H}, \mathrm{H})=8.4 \mathrm{~Hz}, 1 \mathrm{H}\right), 7.93\left(\mathrm{~d},{ }^{3} J(\mathrm{H}, \mathrm{H})=8.8 \mathrm{~Hz}, 1 \mathrm{H}\right), 7.92\left(\mathrm{~d},{ }^{3} J-\right.$ $(\mathrm{H}, \mathrm{H})=8.2 \mathrm{~Hz}, 1 \mathrm{H}), 7.59-7.56(\mathrm{~m}, 3 \mathrm{H}), 7.53-7.42(\mathrm{~m}, 6 \mathrm{H}), 7.39-7.27(\mathrm{~m}$, $7 \mathrm{H}), 7.23\left(\mathrm{t},{ }^{3} J(\mathrm{H}, \mathrm{H})=8.0 \mathrm{~Hz}, 1 \mathrm{H}\right), 7.04\left(\mathrm{~d},{ }^{3} J(\mathrm{H}, \mathrm{H})=8.4 \mathrm{~Hz}, 2 \mathrm{H}\right), 7.00$ $\left(\mathrm{d},{ }^{3} J(\mathrm{H}, \mathrm{H})=8.0 \mathrm{~Hz}, 1 \mathrm{H}\right), 4.92\left(\mathrm{dd},{ }^{2} J(\mathrm{H}, \mathrm{H})=12.3 \mathrm{~Hz},{ }^{3} J(\mathrm{H}, \mathrm{P})=8.0 \mathrm{~Hz}\right.$, $1 \mathrm{H}), 4.70\left(\mathrm{dd},{ }^{2} J(\mathrm{H}, \mathrm{H})=12.3 \mathrm{~Hz},{ }^{3} J(\mathrm{H}, \mathrm{P})=8.0 \mathrm{~Hz}, 1 \mathrm{H}\right), 2.53\left(\mathrm{t},{ }^{3} J\right.$ $(\mathrm{H}, \mathrm{H})=7.8 \mathrm{~Hz}, 2 \mathrm{H}), 1.54(\mathrm{~m}, 2 \mathrm{H}), 1.33(\mathrm{~m}, 2 \mathrm{H}), 0.92 \mathrm{ppm}\left(\mathrm{t},{ }^{3} J(\mathrm{H}, \mathrm{H})=\right.$ $7.3 \mathrm{~Hz}, 3 \mathrm{H}) ;{ }^{13} \mathrm{C}$ NMR $\left(100 \mathrm{MHz}, \mathrm{CD}_{2} \mathrm{Cl}_{2}\right): \delta=167.9,149.2,148.1,139.8$, $139.0,138.5,136.3,135.7,135.6,133.3,133.1,132.2,131.7,131.1,131.0$ $130.9,129.5,129.3,129.1,129.1,128.8,127.4,127.0,126.9,125.8,125.6$, $124.1,123.2,122.5,122.3,121.6,120.8,120.4,119.8,67.2\left(\mathrm{~d},{ }^{2} J(\mathrm{C}, \mathrm{P})=\right.$ $5.6 \mathrm{~Hz}), 35.6,34.3,23.0,14.3 \mathrm{ppm} ;{ }^{31} \mathrm{P} \mathrm{NMR}\left(162 \mathrm{MHz}, \mathrm{CD}_{2} \mathrm{Cl}_{2}\right): \delta=$ 141.3 ppm (s); IR (film): $\tilde{v}=3238.9,3060.5,2954.4,1639.2,1541.8,1230.3$ $823.5 \mathrm{~cm}^{-1}$; HRMS (ESI+): $\mathrm{m} / z$ calcd for $\mathrm{C}_{45} \mathrm{H}_{37} \mathrm{~N}_{2} \mathrm{O}_{5} \mathrm{PNa}: 739.23469$ $[M+\mathrm{Na}]^{+}$; found: 739.23323 . 
$N^{1}$-(4-Butylphenyl)- $N^{2}-(3-(((11 b S)$-dinaphtho[2,1-d:1',2'-f][1,3,2]dioxaphosphepin-4-yloxy)methyl)benzyl)phthalamide $4 \mathbf{b}$ : The product was prepared according to the general procedure 2 starting from $(S)$-binol$\mathrm{PCl}(0.337 \mathrm{~g})$ and alcohol $3 \mathbf{b}(0.40 \mathrm{~g})$ in the presence of $\mathrm{Et}_{3} \mathrm{~N}(0.40 \mathrm{~mL})$. Purification by flash chromatography on silica gel $\left(\mathrm{CH}_{2} \mathrm{Cl}_{2}\right.$ and then 95:5 $\left.\mathrm{CH}_{2} \mathrm{Cl}_{2} / \mathrm{Et}_{2} \mathrm{O}\right)$ gave the product as a white solid. Yield: $0.475 \mathrm{~g}(67 \%)$; m.p. $139-145^{\circ} \mathrm{C} ;[\alpha]_{\mathrm{D}}^{23}=+120.1\left(c=1.0\right.$ in $\left.\mathrm{CH}_{2} \mathrm{Cl}_{2}\right) ;{ }^{1} \mathrm{H} \mathrm{NMR}(400 \mathrm{MHz}$, $\left.\mathrm{CD}_{2} \mathrm{Cl}_{2}\right): \delta=8.80(\mathrm{~s}, 1 \mathrm{H}), 8.06\left(\mathrm{~d},{ }^{3} J(\mathrm{H}, \mathrm{H})=8.8 \mathrm{~Hz}, 1 \mathrm{H}\right), 8.01\left(\mathrm{~d},{ }^{3} J-\right.$ $(\mathrm{H}, \mathrm{H})=8.2 \mathrm{~Hz}, 1 \mathrm{H}), 7.95\left(\mathrm{~d},{ }^{3} J(\mathrm{H}, \mathrm{H})=9.0 \mathrm{~Hz}, 1 \mathrm{H}\right), 7.92\left(\mathrm{~d},{ }^{3} J(\mathrm{H}, \mathrm{H})=\right.$ $7.8 \mathrm{~Hz}, 1 \mathrm{H}), 7.79\left(\mathrm{~d},{ }^{3} J(\mathrm{H}, \mathrm{H})=7.1 \mathrm{~Hz}, 1 \mathrm{H}\right), 7.62\left(\mathrm{dd},{ }^{3} J(\mathrm{H}, \mathrm{H})=7.4 \mathrm{~Hz}\right.$ $\left.{ }^{4} J(\mathrm{H}, \mathrm{H})=1.5 \mathrm{~Hz}, 1 \mathrm{H}\right), 7.58-7.43(\mathrm{~m}, 7 \mathrm{H}), 7.39-7.20(\mathrm{~m}, 9 \mathrm{H}), 7.15\left(\mathrm{~d},{ }^{3} J-\right.$ $(\mathrm{H}, \mathrm{H})=8.3 \mathrm{~Hz}, 2 \mathrm{H}), 6.89\left(\mathrm{t},{ }^{3} J(\mathrm{H}, \mathrm{H})=6.0 \mathrm{~Hz}, 1 \mathrm{H}\right), 4.91\left(\mathrm{dd},{ }^{2} J(\mathrm{H}, \mathrm{H})=\right.$ $\left.12.3 \mathrm{~Hz},{ }^{3} J(\mathrm{H}, \mathrm{P})=8.0 \mathrm{~Hz}, 1 \mathrm{H}\right), 4.71\left(\mathrm{dd},{ }^{2} J(\mathrm{H}, \mathrm{H})=12.3 \mathrm{~Hz},{ }^{3} J(\mathrm{H}, \mathrm{P})=\right.$ $8.2 \mathrm{~Hz}, 1 \mathrm{H}), 4.60\left(\mathrm{~d},{ }^{3} J(\mathrm{H}, \mathrm{H})=6.0 \mathrm{~Hz}, 2 \mathrm{H}\right), 2.62\left(\mathrm{t},{ }^{3} J(\mathrm{H}, \mathrm{H})=7.8 \mathrm{~Hz}\right.$, $2 \mathrm{H}), 1.62(\mathrm{~m}, 2 \mathrm{H}), 1.39(\mathrm{~m}, 2 \mathrm{H}), 0.97 \mathrm{ppm}\left(\mathrm{t},{ }^{3} J(\mathrm{H}, \mathrm{H})=7.3 \mathrm{~Hz}, 3 \mathrm{H}\right)$; ${ }^{13} \mathrm{C}$ NMR $\left(100 \mathrm{MHz}, \mathrm{CD}_{2} \mathrm{Cl}_{2}\right): \delta=170.0,167.3,149.2,148.1,139.7,139.1$, 138.2 , 136.6, 135.7, 135.0, 133.4, 133.1, 132.2, 131.7, 131.0, 130.8, 130.8, $129.4,129.1,129.0,128.9,128.7,127.3,126.8,126.8,125.7,125.5,124.6$, 124.0, 123.1, 122.4, 122.2, 120.7, 120.3, 119.7, $67.1\left(\mathrm{~d},{ }^{2} J(\mathrm{C}, \mathrm{P})=5.7 \mathrm{~Hz}\right)$, 44.3, 35.5, 34.2, 22.9, $14.3 \mathrm{ppm} ;{ }^{31} \mathrm{P} \mathrm{NMR}\left(162 \mathrm{MHz}, \mathrm{CD}_{2} \mathrm{Cl}_{2}\right): \delta=$ $141.8 \mathrm{ppm}$ (s); IR (film): $\tilde{v}=3243.7,3058.6,2954.4,1635.3,1538.9,1230.0$, $825.4 \mathrm{~cm}^{-1}$; HRMS (ESI + ): $\mathrm{m} / z$ calcd for $\mathrm{C}_{46} \mathrm{H}_{39} \mathrm{~N}_{2} \mathrm{O}_{5} \mathrm{PNa}: 753.24888$ $[M+\mathrm{Na}]^{+}$; found: 753.24782 .

$N^{1}$-(4-Butylphenyl)- $N^{2}$-(4-(((11bS)-dinaphtho[2,1-d:1',2'-f][1,3,2]dioxaphosphepin-4-yloxy)methyl)phenyl)phthalamide $4 \mathbf{c}$ : The product was prepared according to the general procedure 1 starting from $(S)$-binol$\mathrm{PCl}(0.174 \mathrm{~g})$ and alcohol $\mathbf{3 c}(0.200 \mathrm{~g})$ in the presence of $\mathrm{Et}_{3} \mathrm{~N}$ $(0.208 \mathrm{~mL})$. Purification by flash chromatography on silica gel $\left(\mathrm{CH}_{2} \mathrm{Cl}_{2}\right.$ and then 95:5 $\left.\mathrm{CH}_{2} \mathrm{Cl}_{2} / \mathrm{Et}_{2} \mathrm{O}\right)$ gave the product as a white solid. Yield: $0.219 \mathrm{~g} \quad(62 \%)$; m.p. $150-159^{\circ} \mathrm{C} ;[\alpha]_{\mathrm{D}}^{18}=+209.1 \quad\left(c=0.8\right.$ in $\left.\mathrm{CH}_{2} \mathrm{Cl}_{2}\right)$; ${ }^{1} \mathrm{H}$ NMR $\left(400 \mathrm{MHz}, \mathrm{CD}_{2} \mathrm{Cl}_{2}\right): \delta=8.96(\mathrm{~s}, 1 \mathrm{H}), 8.53(\mathrm{~s}, 1 \mathrm{H}), 8.06\left(\mathrm{~d},{ }^{3} J-\right.$ $(\mathrm{H}, \mathrm{H})=8.8 \mathrm{~Hz}, 1 \mathrm{H}), 8.01,\left(\mathrm{~d},{ }^{3} J(\mathrm{H}, \mathrm{H})=8.2 \mathrm{~Hz}, 1 \mathrm{H}\right), 7.97\left(\mathrm{~d},{ }^{3} J(\mathrm{H}, \mathrm{H})=\right.$ $8.6 \mathrm{~Hz}, 2 \mathrm{H}), 7.78(\mathrm{~m}, 1 \mathrm{H}), 7.72(\mathrm{~m}, 1 \mathrm{H}), 7.65\left(\mathrm{~d},{ }^{3} J(\mathrm{H}, \mathrm{H})=8.2 \mathrm{~Hz}, 2 \mathrm{H}\right)$, $7.60-7.46(\mathrm{~m}, 7 \mathrm{H}), 7.39-7.29(\mathrm{~m}, 7 \mathrm{H}), 7.18\left(\mathrm{~d},{ }^{3} J(\mathrm{H}, \mathrm{H})=8.3 \mathrm{~Hz}, 2 \mathrm{H}\right)$, $5.00\left(\mathrm{dd},{ }^{2} J(\mathrm{H}, \mathrm{H})=12.1 \mathrm{~Hz},{ }^{3} J(\mathrm{H}, \mathrm{P})=8.0 \mathrm{~Hz}, 1 \mathrm{H}\right), 4.78\left(\mathrm{dd},{ }^{2} J(\mathrm{H}, \mathrm{H})=\right.$ $\left.12.1 \mathrm{~Hz},{ }^{3} J(\mathrm{H}, \mathrm{P})=8.3 \mathrm{~Hz}, 1 \mathrm{H}\right), 2.61\left(\mathrm{t},{ }^{3} J(\mathrm{H}, \mathrm{H})=7.8 \mathrm{~Hz}, 2 \mathrm{H}\right), 1.60(\mathrm{~m}$, $2 \mathrm{H}), \quad 1.37(\mathrm{~m}, 2 \mathrm{H}), \quad 0.95 \mathrm{ppm} \quad\left(\mathrm{t},{ }^{3} \mathrm{~J}(\mathrm{H}, \mathrm{H})=7.3 \mathrm{~Hz}, \quad 3 \mathrm{H}\right) ;{ }^{13} \mathrm{C} \mathrm{NMR}$ $\left(100 \mathrm{MHz}, \mathrm{CD}_{2} \mathrm{Cl}_{2}\right): \delta=168.2,168.0,149.3,148.2,139.2,136.8,135.6$, $135.5,133.4,133.1,132.2,131.7,131.0,130.7,130.3,130.2,129.0,128.8$, $128.5,127.3,126.8,125.7,125.5,124.7,124.6,123.2,122.4,122.2,120.6$, $120.5,67.1\left(\mathrm{~d},{ }^{2} J(\mathrm{C}, \mathrm{P})=4.6 \mathrm{~Hz}\right), 35.6,34.2,22.9,14.3 \mathrm{ppm} ;{ }^{31} \mathrm{P}$ NMR $\left(162 \mathrm{MHz}, \mathrm{CD}_{2} \mathrm{Cl}_{2}\right): \delta=141.8 \mathrm{ppm}$ (s); IR (film): $\tilde{v}=3240.1,3059.1$, 2954.4, 1639.2, 1541.8, 1230.0, 823.5 $\mathrm{cm}^{-1}$; HRMS (ESI +$): \mathrm{m} / z$ calcd for $\mathrm{C}_{45} \mathrm{H}_{37} \mathrm{~N}_{2} \mathrm{O}_{5} \mathrm{PNa}: 739.23323[M+\mathrm{Na}]^{+}$; found: 739.23437

$N^{1}$-(4-Butylphenyl)- $N^{2}$-(4-(((11 bS)-dinaphtho[2,1-d:1',2'-f][1,3,2]dioxaphosphepin-4-yloxy)methyl)benzyl)phthalamide 4d: The product was prepared according to the general procedure 1 starting from $(S)$-binol$\mathrm{PCl}(0.278 \mathrm{~g})$ and alcohol $3 \mathrm{~d}(0.30 \mathrm{~g})$ in the presence of $\mathrm{Et}_{3} \mathrm{~N}(0.30 \mathrm{~mL})$. Purification by flash chromatography on silica gel $\left(\mathrm{CH}_{2} \mathrm{Cl}_{2}\right.$ and then 95:5 $\left.\mathrm{CH}_{2} \mathrm{Cl}_{2} / \mathrm{Et}_{2} \mathrm{O}\right)$ gave the product as a white solid. Yield: $0.342 \mathrm{~g}(65 \%)$; m.p. $110-130^{\circ} \mathrm{C} ;[\alpha]_{\mathrm{D}}^{18}=+239.6\left(c=0.93\right.$ in $\left.\mathrm{CH}_{2} \mathrm{Cl}_{2}\right) ;{ }^{1} \mathrm{H} \mathrm{NMR}(400 \mathrm{MHz}$, $\left.\mathrm{CD}_{2} \mathrm{Cl}_{2}\right): \delta=8.88(\mathrm{~s}, 1 \mathrm{H}), 8.06\left(\mathrm{~d},{ }^{3} J(\mathrm{H}, \mathrm{H})=8.8 \mathrm{~Hz}, 1 \mathrm{H}\right), 8.01\left(\mathrm{~d},{ }^{3} J-\right.$ $(\mathrm{H}, \mathrm{H})=8.3 \mathrm{~Hz}, 1 \mathrm{H}), 7.97\left(\mathrm{~d},{ }^{3} J(\mathrm{H}, \mathrm{H})=8.7 \mathrm{~Hz}, 2 \mathrm{H}\right), 7.80\left(\mathrm{~d},{ }^{3} J(\mathrm{H}, \mathrm{H})=\right.$ $7.0 \mathrm{~Hz}, 1 \mathrm{H}), 7.62-7.46(\mathrm{~m}, 8 \mathrm{H}), 7.39-7.30(\mathrm{~m}, 7 \mathrm{H}), 7.20\left(\mathrm{~d},{ }^{3} J(\mathrm{H}, \mathrm{H})=\right.$ $7.4 \mathrm{~Hz}, 2 \mathrm{H}), 7.18\left(\mathrm{~d},{ }^{3} J(\mathrm{H}, \mathrm{H})=7.4 \mathrm{~Hz}, 2 \mathrm{H}\right), 6.88\left(\mathrm{t},{ }^{3} J(\mathrm{H}, \mathrm{H})=5.9 \mathrm{~Hz}\right.$, $1 \mathrm{H}), 4.97\left(\mathrm{dd},{ }^{2} J(\mathrm{H}, \mathrm{H})=12.2 \mathrm{~Hz},{ }^{3} J(\mathrm{H}, \mathrm{P})=8.0 \mathrm{~Hz}, 1 \mathrm{H}\right), 4.76\left(\mathrm{dd},{ }^{2} J-\right.$ $\left.(\mathrm{H}, \mathrm{H})=12.2 \mathrm{~Hz},{ }^{3} J(\mathrm{H}, \mathrm{P})=8.2 \mathrm{~Hz}, 1 \mathrm{H}\right), 4.60\left(\mathrm{~d},{ }^{3} J(\mathrm{H}, \mathrm{H})=5.9 \mathrm{~Hz}, 2 \mathrm{H}\right)$, $2.61\left(\mathrm{t},{ }^{3} J(\mathrm{H}, \mathrm{H})=7.6 \mathrm{~Hz}, 2 \mathrm{H}\right), 1.61(\mathrm{~m}, 2 \mathrm{H}), 1.37(\mathrm{~m}, 2 \mathrm{H}), 0.95 \mathrm{ppm}(\mathrm{t}$, $\left.{ }^{3} J(\mathrm{H}, \mathrm{H})=7.3 \mathrm{~Hz}, 3 \mathrm{H}\right) ;{ }^{13} \mathrm{C}$ NMR $\left(100 \mathrm{MHz}, \mathrm{CD}_{2} \mathrm{Cl}_{2}\right): \delta=170.0,167.4$, $149.3,148.1,139.7,138.7,137.0,136.6,135.7,135.0,133.4,133.1,132.2$, $131.7,131.1,130.8,130.7,130.6,129.2,129.1,129.0,129.0,128.5,128.4$, $128.3,127.3,126.9,126.9,125.7,125.6,124.6,123.2,122.3,122.1,120.8$, $67.0\left(\mathrm{~d},{ }^{2} J(\mathrm{C}, \mathrm{P})=5.7 \mathrm{~Hz}\right), 44.2, \quad 35.6, \quad 34.3,22.9,14.3 \mathrm{ppm} ;{ }^{31} \mathrm{P}$ NMR (162 MHz, $\mathrm{CD}_{2} \mathrm{Cl}_{2}$ ): $\delta=141.6 \mathrm{ppm}$ (s); IR (film): $\tilde{v}=3259.1,3058.6$, 2954.4, 1637.3, 1540.8, 1230.0, $824.4 \mathrm{~cm}^{-1}$; HRMS (ESI+): $\mathrm{m} / \mathrm{z}$ calcd for $\mathrm{C}_{46} \mathrm{H}_{39} \mathrm{~N}_{2} \mathrm{O}_{5} \mathrm{PNa}: 753.24888[M+\mathrm{Na}]^{+}$; found: 753.24963 .

$N^{1}$-(4-Butylphenyl)- $N^{2}$-(2-(((11 bS)-dinaphtho[2,1- $\left.d: 1^{\prime}, 2^{\prime}-f\right][1,3,2]$ dioxaphosphepin-4-yloxy)methyl)benzyl)phthalamide $4 \mathbf{e}$ : The product was prepared according to the general procedure 2 starting from $(S)$-binol$\mathrm{PCl}(0.287 \mathrm{~g})$ and alcohol 3e $(0.340 \mathrm{~g})$ in the presence of $\mathrm{Et}_{3} \mathrm{~N}$ $(0.342 \mathrm{~mL})$. Purification by flash chromatography on silica gel $\left(\mathrm{CH}_{2} \mathrm{Cl}_{2}\right.$ and then 95:5 $\left.\mathrm{CH}_{2} \mathrm{Cl}_{2} / \mathrm{Et}_{2} \mathrm{O}\right)$ gave the product as a white solid. Yield: $0.412 \mathrm{~g}(69 \%)$; m.p. $115-122^{\circ} \mathrm{C} ;[\alpha]_{\mathrm{D}}^{20}=+313.5\left(c=0.87\right.$ in $\left.\mathrm{CH}_{2} \mathrm{Cl}_{2}\right)$; ${ }^{1} \mathrm{H}$ NMR $\left(400 \mathrm{MHz}, \mathrm{CD}_{2} \mathrm{Cl}_{2}\right): \delta=8.91(\mathrm{~s}, 1 \mathrm{H}), 8.04\left(\mathrm{~d},{ }^{3} J(\mathrm{H}, \mathrm{H})=8.8 \mathrm{~Hz}\right.$, $1 \mathrm{H}), 8.00\left(\mathrm{~d},{ }^{3} J(\mathrm{H}, \mathrm{H})=8.2 \mathrm{~Hz}, 1 \mathrm{H}\right), 7.89\left(\mathrm{~d},{ }^{3} J(\mathrm{H}, \mathrm{H})=8.8 \mathrm{~Hz}, 1 \mathrm{H}\right), 7.88$ $\left(\mathrm{d},{ }^{3} J(\mathrm{H}, \mathrm{H})=8.0 \mathrm{~Hz}, 1 \mathrm{H}\right), 7.70\left(\mathrm{~d},{ }^{3} J(\mathrm{H}, \mathrm{H})=7.7 \mathrm{~Hz}, 1 \mathrm{H}\right), 7.52-7.38(\mathrm{~m}$, $7 \mathrm{H}), 7.34-7.20(\mathrm{~m}, 10 \mathrm{H}), 7.16\left(\mathrm{~d},{ }^{3} J(\mathrm{H}, \mathrm{H})=8.3 \mathrm{~Hz}, 2 \mathrm{H}\right), 6.76\left(\mathrm{t},{ }^{3} J-\right.$ $(\mathrm{H}, \mathrm{H})=5.4 \mathrm{~Hz}, 1 \mathrm{H}), 5.13\left(\mathrm{dd},{ }^{2} J(\mathrm{H}, \mathrm{H})=12.1 \mathrm{~Hz},{ }^{3} J(\mathrm{H}, \mathrm{P})=7.8 \mathrm{~Hz}, 1 \mathrm{H}\right)$, $4.98\left(\mathrm{dd},{ }^{2} J(\mathrm{H}, \mathrm{H})=12.1 \mathrm{~Hz},{ }^{3} J(\mathrm{H}, \mathrm{P})=8.4 \mathrm{~Hz}, 1 \mathrm{H}\right), 4.61\left(\mathrm{dd},{ }^{2} J(\mathrm{H}, \mathrm{H})=\right.$ $\left.14.7 \mathrm{~Hz},{ }^{3} J(\mathrm{H}, \mathrm{P})=5.9 \mathrm{~Hz}, 1 \mathrm{H}\right), 4.53\left(\mathrm{dd},{ }^{2} J(\mathrm{H}, \mathrm{H})=14.7 \mathrm{~Hz},{ }^{3} J(\mathrm{H}, \mathrm{P})=\right.$ $5.7 \mathrm{~Hz}, 1 \mathrm{H}), 2.63\left(\mathrm{t},{ }^{3} J(\mathrm{H}, \mathrm{H})=7.8 \mathrm{~Hz}, 2 \mathrm{H}\right), 1.64(\mathrm{~m}, 2 \mathrm{H}), 1.40(\mathrm{~m}, 2 \mathrm{H})$ $0.98 \mathrm{ppm}\left(\mathrm{t},{ }^{3} J(\mathrm{H}, \mathrm{H})=7.8 \mathrm{~Hz}, 3 \mathrm{H}\right) ;{ }^{13} \mathrm{C} \mathrm{NMR}\left(100 \mathrm{MHz}, \mathrm{CD}_{2} \mathrm{Cl}_{2}\right): \delta=$ $169.6,166.8,148.9,147.8,139.7,137.3,136.5,135.7,135.6,134.7,133.3$ $133.0,132.2$, 131.6, 131.1, 130.8, 130.7, 130.4, 130.2, 129.7, 129.6, 129.3, $129.0,128.9,128.5,128.3,127.3,127.3,126.9,126.9,125.8,125.6,124.5$, 123.2, 122.2, 122.0, 121.9, 120.6, $65.6\left(\mathrm{~d},{ }^{2} J(\mathrm{C}, \mathrm{P})=9.3 \mathrm{~Hz}\right), 41.9,35.6,34.3$, 22.9, $14.3 \mathrm{ppm} ;{ }^{31} \mathrm{P}$ NMR (162 MHz, $\left.\mathrm{CD}_{2} \mathrm{Cl}_{2}\right): \delta=144.0 \mathrm{ppm}$ (s); IR (film): $\tilde{v}=3245.6,3058.8,2954.4,1636.3,1541.8,1230.0,824.4 \mathrm{~cm}^{-1}$; HRMS (ESI+): $\mathrm{m} / \mathrm{z}$ calcd for $\mathrm{C}_{46} \mathrm{H}_{39} \mathrm{~N}_{2} \mathrm{O}_{5} \mathrm{PNa}: 753.24888[M+\mathrm{Na}]^{+}$; found: 753.24983 .

$N^{1}$-(4-Butylphenyl)- $N^{2}$-(3-(((11 bS)-dinaphtho[2,1- $\left.d: 1^{\prime}, 2^{\prime}-f\right][1,3,2]$ dioxaphosphepin-4-yloxy)methyl)phenethyl)phthalamide $4 \mathrm{f}$ : The product was prepared according to the general procedure 1 starting from $(S)$-binol$\mathrm{PCl}(0.137 \mathrm{~g})$ and alcohol $\mathbf{3 f}(0.390 \mathrm{~g})$ in the presence of $\mathrm{Et}_{3} \mathrm{~N}$ $(0.163 \mathrm{~mL})$. Purification by flash chromatography on silica gel $\left(\mathrm{CH}_{2} \mathrm{Cl}_{2}\right.$ and then 95:5 $\left.\mathrm{CH}_{2} \mathrm{Cl}_{2} / \mathrm{Et}_{2} \mathrm{O}\right)$ gave the product as a white solid. Yield: 0.183 g (63\%); m.p. $105-116^{\circ} \mathrm{C} ;[\alpha]_{\mathrm{D}}^{20}=+201.7$ ( $c=0.8$ in $\left.\mathrm{CH}_{2} \mathrm{Cl}_{2}\right)$; ${ }^{1} \mathrm{H}$ NMR $\left(400 \mathrm{MHz}, \mathrm{CD}_{2} \mathrm{Cl}_{2}\right): \delta=9.21(\mathrm{~s}, 1 \mathrm{H}), 8.06\left(\mathrm{~d},{ }^{3} J(\mathrm{H}, \mathrm{H})=8.8 \mathrm{~Hz}\right.$, $1 \mathrm{H}), 8.01\left(\mathrm{~d},{ }^{3} J(\mathrm{H}, \mathrm{H})=8.3 \mathrm{~Hz}, 1 \mathrm{H}\right), 7.96\left(\mathrm{~d},{ }^{3} J(\mathrm{H}, \mathrm{H})=8.7 \mathrm{~Hz}, 2 \mathrm{H}\right), 7.73$ $\left(\mathrm{d},{ }^{3} J(\mathrm{H}, \mathrm{H})=7.4 \mathrm{~Hz}, 1 \mathrm{H}\right), 7.58\left(\mathrm{~d},{ }^{3} J(\mathrm{H}, \mathrm{H})=8.8 \mathrm{~Hz}, 1 \mathrm{H}\right), 7.57\left(\mathrm{~d},{ }^{3} J-\right.$ $(\mathrm{H}, \mathrm{H})=8.1 \mathrm{~Hz}, 2 \mathrm{H}), 7.52-7.28(\mathrm{~m}, 11 \mathrm{H}), 7.19-7.17(\mathrm{~m}, 5 \mathrm{H}), 6.55(\mathrm{bs}$, $1 \mathrm{H}), 5.00\left(\mathrm{dd},{ }^{2} J(\mathrm{H}, \mathrm{H})=12.2 \mathrm{~Hz},{ }^{3} J(\mathrm{H}, \mathrm{P})=7.9 \mathrm{~Hz}, 1 \mathrm{H}\right), 4.80\left(\mathrm{dd},{ }^{2} J-\right.$ $\left.(\mathrm{H}, \mathrm{H})=12.2 \mathrm{~Hz},{ }^{3} J(\mathrm{H}, \mathrm{P})=8.4 \mathrm{~Hz}, 1 \mathrm{H}\right), 3.64(\mathrm{~m}, 2 \mathrm{H}), 2.88\left(\mathrm{t},{ }^{3} J(\mathrm{H}, \mathrm{P})=\right.$ $7.1 \mathrm{~Hz}, 2 \mathrm{H}), 2.62\left(\mathrm{t},{ }^{3} J(\mathrm{H}, \mathrm{P})=7.6 \mathrm{~Hz}, 2 \mathrm{H}\right), 1.63(\mathrm{~m}, 2 \mathrm{H}), 1.38(\mathrm{~m}, 2 \mathrm{H})$, $0.96 \mathrm{ppm}\left(\mathrm{t},{ }^{3} J(\mathrm{H}, \mathrm{P})=7.3 \mathrm{~Hz}, 3 \mathrm{H}\right) ;{ }^{13} \mathrm{C} \mathrm{NMR}\left(100 \mathrm{MHz}, \mathrm{CD}_{2} \mathrm{Cl}_{2}\right): \delta=$ $170.3,167.1,149.2,148.1,139.9,139.6,138.1,136.8,135.6,135.4,133.4$, $133.1,132.2,131.7,131.1,130.8,130.4,129.3,129.2,129.1,129.0,128.6$, $128.2,127.3,126.9,126.3,125.7,125.6,124.6,123.2,122.4,122.1,120.7$ $67.2\left(\mathrm{~d},{ }^{2} J(\mathrm{C}, \mathrm{P})=4.6 \mathrm{~Hz}\right), 41.8,35.8,35.6,34.3,22.9,14.3 \mathrm{ppm} ;{ }^{31} \mathrm{P}$ NMR $\left(162 \mathrm{MHz}, \mathrm{CD}_{2} \mathrm{Cl}_{2}\right): \delta=142.2 \mathrm{ppm}$ (s); IR (film): $\tilde{v}=3240.6,3058.5$, 2954.4, 1636.3, 1541.8, 1230.0, 825.4 $\mathrm{cm}^{-1}$; HRMS (ESI+): $\mathrm{m} / \mathrm{z}$ calcd for $\mathrm{C}_{47} \mathrm{H}_{42} \mathrm{~N}_{2} \mathrm{O}_{5} \mathrm{P}: 745.28259[M+\mathrm{H}]^{+}$; found: 745.28262 , and $\mathrm{m} / \mathrm{z}$ calcd for $\mathrm{C}_{47} \mathrm{H}_{41} \mathrm{~N}_{2} \mathrm{O}_{5} \mathrm{PNa}: 767.26453[M+\mathrm{Na}]^{+}$; found: 767.26300 .

$N^{1}$-(4-Butylphenyl)- $N^{2}$-(4-(((11 bS)-dinaphtho[2,1-d:1',2'-f][1,3,2]dioxaphosphepin-4-yloxy)methyl)phenethyl)phthalamide $4 \mathrm{~g}$ : The product was prepared according to the general procedure 2 starting from $(S)$-binol$\mathrm{PCl}(0.275 \mathrm{~g})$ and alcohol $\mathbf{3 g}(0.338 \mathrm{~g})$ in the presence of $\mathrm{Et}_{3} \mathrm{~N}$ $(0.328 \mathrm{~mL})$. Purification by flash chromatography on silica gel $\left(\mathrm{CH}_{2} \mathrm{Cl}_{2}\right.$ and then 95:5 $\left.\mathrm{CH}_{2} \mathrm{Cl}_{2} / \mathrm{Et}_{2} \mathrm{O}\right)$ gave the product as a white solid. Yield: $0.415 \mathrm{~g}(71 \%)$; m.p. $109-117^{\circ} \mathrm{C} ; \quad[\alpha]_{\mathrm{D}}^{20}=+248.8 \quad\left(c=0.8\right.$ in $\left.\mathrm{CH}_{2} \mathrm{Cl}_{2}\right)$; ${ }^{1} \mathrm{H}$ NMR $\left(400 \mathrm{MHz}, \mathrm{CD}_{2} \mathrm{Cl}_{2}\right): \delta=9.22(\mathrm{~s}, 1 \mathrm{H}), 8.06\left(\mathrm{~d},{ }^{3} J(\mathrm{H}, \mathrm{P})=8.8 \mathrm{~Hz}\right.$, $1 \mathrm{H}), 8.01\left(\mathrm{~d},{ }^{3} J(\mathrm{H}, \mathrm{P})=8.3 \mathrm{~Hz}, 1 \mathrm{H}\right), 7.96\left(\mathrm{~d},{ }^{3} J(\mathrm{H}, \mathrm{P})=9.0 \mathrm{~Hz}, 2 \mathrm{H}\right), 7.74$ $\left(\mathrm{d},{ }^{3} J(\mathrm{H}, \mathrm{P})=7.4 \mathrm{~Hz}, 1 \mathrm{H}\right), 7.58(\mathrm{~m}, 3 \mathrm{H}), 7.52-7.29(\mathrm{~m}, 10 \mathrm{H}), 7.23(\mathrm{~m}$, $4 \mathrm{H}), 7.19\left(\mathrm{~d},{ }^{3} J(\mathrm{H}, \mathrm{P})=8.5 \mathrm{~Hz}, 2 \mathrm{H}\right), 6.62\left(\mathrm{t},{ }^{3} J(\mathrm{H}, \mathrm{P})=5.6 \mathrm{~Hz}, 1 \mathrm{H}\right), 4.98$ $\left(\mathrm{dd},{ }^{2} J(\mathrm{H}, \mathrm{H})=12.1 \mathrm{~Hz},{ }^{3} J(\mathrm{H}, \mathrm{P})=8.0 \mathrm{~Hz}, 1 \mathrm{H}\right), 4.77 \quad\left(\mathrm{dd},{ }^{2} J(\mathrm{H}, \mathrm{H})=\right.$ $\left.12.1 \mathrm{~Hz},{ }^{3} J(\mathrm{H}, \mathrm{P})=8.2 \mathrm{~Hz}, 1 \mathrm{H}\right), 3.65\left(\mathrm{q},{ }^{3} J(\mathrm{H}, \mathrm{H})=6 \mathrm{~Hz}, 2 \mathrm{H}\right), 2.89\left(\mathrm{t},{ }^{3} J-\right.$ $(\mathrm{H}, \mathrm{P})=7.1 \mathrm{~Hz}, 2 \mathrm{H}), 2.63\left(\mathrm{t},{ }^{3} J(\mathrm{H}, \mathrm{P})=7.6 \mathrm{~Hz}, 2 \mathrm{H}\right), 1.63(\mathrm{~m}, 2 \mathrm{H}), 1.39$ $(\mathrm{m}, \quad 2 \mathrm{H}), \quad 0.97 \mathrm{ppm} \quad\left(\mathrm{t}, \quad{ }^{3} J(\mathrm{H}, \mathrm{P})=7.3 \mathrm{~Hz}, \quad 3 \mathrm{H}\right) ;{ }^{13} \mathrm{C} \mathrm{NMR} \quad(100 \mathrm{MHz}$, $\left.\mathrm{CD}_{2} \mathrm{Cl}_{2}\right): \delta=170.2,167.5,149.3,148.1,139.8,139.4,137.0,135.9,135.7$, $135.4,133.4,133.1,132.2,131.7,131.1,130.8,130.5,130.2,129.4,129.1$, $129.0,129.0,128.4,128.1,127.3,126.9,126.9,125.7,125.6,124.6,123.2$, 122.4, 122.1, 120.7, $67.2\left(\mathrm{~d},{ }^{2} J(\mathrm{C}, \mathrm{P})=4.8 \mathrm{~Hz}\right), 41.8,35.6,35.5,34.3,22.9$, $14.4 \mathrm{ppm} ;{ }^{31} \mathrm{P}$ NMR (162 MHz, $\mathrm{CD}_{2} \mathrm{Cl}_{2}$ ): $\delta=141.9 \mathrm{ppm}$ (s); IR (film): $\tilde{v}=$ 3252.4, 3073.0, 2954.3, 1635.3, 1540.8, 1230.0, $823.5 \mathrm{~cm}^{-1}$; HRMS (ESI+): $m / z$ calcd for $\mathrm{C}_{47} \mathrm{H}_{41} \mathrm{~N}_{2} \mathrm{O}_{5} \mathrm{PNa}: 767.26453[M+\mathrm{Na}]^{+}$; found: 767.26494 . 
$N^{1}$-(3,5-Bis(trifluoromethyl)phenyl)- $N^{2}-\left(3-\left(\left((11 b S)-d i n a p h t h o\left[2,1-d: 1^{\prime}, 2^{\prime}-\right.\right.\right.\right.$ $f][1,3,2]$ dioxaphosphepin-4-yloxy)methyl)phenyl)phthalamide $4 \mathbf{h}$ : The product was prepared according to the general procedure 1 starting from $(S)$-binol-PCl $(0.168 \mathrm{~g})$ and alcohol $\mathbf{3 h}(0.230 \mathrm{~g})$ in the presence of $\mathrm{Et}_{3} \mathrm{~N}$ $(0.2 \mathrm{~mL})$. Purification by flash chromatography on silica gel $\left(\mathrm{CH}_{2} \mathrm{Cl}_{2}\right.$ and then 95:5 $\left.\mathrm{CH}_{2} \mathrm{Cl}_{2} / \mathrm{Et}_{2} \mathrm{O}\right)$ gave the product as a white solid. Yield: $0.296 \mathrm{~g}$ (78\%); m.p. $165-176{ }^{\circ} \mathrm{C} ;[\alpha]_{\mathrm{D}}^{21}=+216.7\left(c=0.75\right.$ in $\left.\mathrm{CH}_{2} \mathrm{Cl}_{2}\right) ;{ }^{1} \mathrm{H}$ NMR $\left(400 \mathrm{MHz}, \mathrm{CD}_{2} \mathrm{Cl}_{2}\right): \delta=10.53(\mathrm{~s}, 1 \mathrm{H}), 9.16(\mathrm{~s}, 1 \mathrm{H}), 8.07(\mathrm{~s}, 2 \mathrm{H}), 7.96(\mathrm{~d}$, $\left.{ }^{3} J(\mathrm{H}, \mathrm{H})=8.8 \mathrm{~Hz}, 1 \mathrm{H}\right), 7.92\left(\mathrm{~d},{ }^{3} J(\mathrm{H}, \mathrm{H})=8.2 \mathrm{~Hz}, 1 \mathrm{H}\right), 7.85\left(\mathrm{~d},{ }^{3} J(\mathrm{H}, \mathrm{H})=\right.$ $8.7 \mathrm{~Hz}, 1 \mathrm{H}), 7.83\left(\mathrm{~d},{ }^{3} J(\mathrm{H}, \mathrm{H})=7.5 \mathrm{~Hz}, 1 \mathrm{H}\right), 7.63(\mathrm{~s}, 1 \mathrm{H}), 7.45\left(\mathrm{~d},{ }^{3} J-\right.$ $(\mathrm{H}, \mathrm{H})=8.8 \mathrm{~Hz}, 1 \mathrm{H}), 7.42-7.34(\mathrm{~m}, 4 \mathrm{H}), 7.31-7.15(\mathrm{~m}, 6 \mathrm{H}), 7.04(\mathrm{~m}$, $1 \mathrm{H}), 6.96\left(\mathrm{~d},{ }^{3} J(\mathrm{H}, \mathrm{H})=7.7 \mathrm{~Hz}, 2 \mathrm{H}\right), 6.89(\mathrm{~m}, 2 \mathrm{H}), 4.87\left(\mathrm{dd},{ }^{2} J(\mathrm{H}, \mathrm{H})=\right.$ $\left.12.4 \mathrm{~Hz},{ }^{3} J(\mathrm{H}, \mathrm{P})=8.1 \mathrm{~Hz}, 1 \mathrm{H}\right), 4.69 \mathrm{ppm} \quad\left(\mathrm{dd},{ }^{2} J(\mathrm{H}, \mathrm{H})=12.4 \mathrm{~Hz},{ }^{3} J-\right.$ $(\mathrm{H}, \mathrm{P})=8.2 \mathrm{~Hz}, 1 \mathrm{H}) ;{ }^{13} \mathrm{C} \mathrm{NMR} \quad\left(100 \mathrm{MHz}, \mathrm{CD}_{2} \mathrm{Cl}_{2}\right): \delta=168.7,168.4$, 149.1, 148.0, 140.6, 138.7, 138.5, 135.7, 134.8, 133.3, 133.1, 132.2, 132.1 (q, $\left.{ }^{2} J(\mathrm{C}, \mathrm{F})=33.3 \mathrm{~Hz}\right), 131.6,131.2,131.0,130.8,130.7,129.6,129.0,128.9$, $128.5,128.0,127.3,127.3,126.9,126.8,125.7,125.5,124.6,124.5,123.7$ (q, $\left.{ }^{1} J(\mathrm{C}, \mathrm{F})=272.6 \mathrm{~Hz}\right), \quad 123.1, \quad 122.3, \quad 122.0, \quad 120.4, \quad 119.9, \quad 119.4, \quad 117.8$, $66.9 \mathrm{ppm} \quad\left(\mathrm{d}, \quad{ }^{2} J(\mathrm{C}, \mathrm{P})=6.7 \mathrm{~Hz}\right) ; \quad{ }^{31} \mathrm{P} \mathrm{NMR} \quad\left(162 \mathrm{MHz}, \quad \mathrm{CD}_{2} \mathrm{Cl}_{2}\right): \quad \delta=$ $141.0 \mathrm{ppm}(\mathrm{s}) ;{ }^{19} \mathrm{~F} \mathrm{NMR}\left(282 \mathrm{MHz}, \mathrm{CD}_{2} \mathrm{Cl}_{2}\right): \delta=-62.2 \mathrm{ppm}$ (s); IR (film): $\tilde{v}=3220.4,1638.2,1380.8,1276.0,1230.0,823.5 \mathrm{~cm}^{-1}$; HRMS (ESI+): $m / z$ calcd for $\mathrm{C}_{43} \mathrm{H}_{27} \mathrm{~F}_{6} \mathrm{~N}_{2} \mathrm{O}_{5} \mathrm{PNa}: 819.14540[M+\mathrm{Na}]^{+}$; found: 819.14729 .

$N^{1}$-(3,5-Bis(trifluoromethyl)phenyl)- $N^{2}-\left(3-\left(\left((11 b S)-d i n a p h t h o\left[2,1-d: 1^{\prime}, 2^{\prime}-\right.\right.\right.\right.$ $f][1,3,2]$ dioxaphosphepin-4-yloxy)methyl)benzyl)phthalamide $4 \mathbf{i}:$ The product was prepared according to the general procedure 1 starting from $(S)$-binol-PCl $(0.234 \mathrm{~g})$ and alcohol $3 \mathbf{i}(0.330 \mathrm{~g})$ in the presence of $\mathrm{Et}_{3} \mathrm{~N}$ $(0.279 \mathrm{~mL})$. Purification by flash chromatography on silica gel $\left(\mathrm{CH}_{2} \mathrm{Cl}_{2}\right.$ and then 95:5 $\left.\mathrm{CH}_{2} \mathrm{Cl}_{2} / \mathrm{Et}_{2} \mathrm{O}\right)$ gave the product as a white solid. Yield: $0.413 \mathrm{~g} \quad(76 \%)$; m.p. $138-145^{\circ} \mathrm{C} ;[\alpha]_{\mathrm{D}}^{21}=+229.8\left(c=0.95\right.$ in $\left.\mathrm{CH}_{2} \mathrm{Cl}_{2}\right)$; ${ }^{1} \mathrm{H}$ NMR $\left(400 \mathrm{MHz}, \mathrm{CD}_{2} \mathrm{Cl}_{2}\right): \delta=10.81(\mathrm{~s}, 1 \mathrm{H}), 8.16(\mathrm{~s}, 2 \mathrm{H}), 8.02\left(\mathrm{~d},{ }^{3} J\right.$ $(\mathrm{H}, \mathrm{H})=8.8 \mathrm{~Hz}, 1 \mathrm{H}), 7.98\left(\mathrm{~d},{ }^{3} J(\mathrm{H}, \mathrm{H})=8.2 \mathrm{~Hz}, 1 \mathrm{H}\right), 7.92\left(\mathrm{~d},{ }^{3} J(\mathrm{H}, \mathrm{H})=\right.$ $8.8 \mathrm{~Hz}, 1 \mathrm{H}), 7.90\left(\mathrm{~d},{ }^{3} J(\mathrm{H}, \mathrm{H})=8.1 \mathrm{~Hz}, 1 \mathrm{H}\right), 7.54-7.25(\mathrm{~m}, 12 \mathrm{H}), 7.22$ $7.16(\mathrm{~m}, 2 \mathrm{H}), 6.69\left(\mathrm{t},{ }^{3} J(\mathrm{H}, \mathrm{H})=5.7 \mathrm{~Hz}, 1 \mathrm{H}\right), 5.03\left(\mathrm{dd},{ }^{2} J(\mathrm{H}, \mathrm{H})=12.3 \mathrm{~Hz}\right.$, $\left.{ }^{3} J(\mathrm{H}, \mathrm{P})=8.2 \mathrm{~Hz}, 1 \mathrm{H}\right), 4.85\left(\mathrm{dd},{ }^{2} J(\mathrm{H}, \mathrm{H})=12.3 \mathrm{~Hz},{ }^{3} J(\mathrm{H}, \mathrm{P})=8.2 \mathrm{~Hz}, 1 \mathrm{H}\right)$, $4.65 \mathrm{ppm}$ (AB system, 2H); ${ }^{13} \mathrm{C} \mathrm{NMR}\left(100 \mathrm{MHz}, \mathrm{CD}_{2} \mathrm{Cl}_{2}\right): \delta=170.0$, 168.8, 149.2, 148.0, 141.2, 139.5, 138.3, 135.1, 134.4, 133.3, 133.1, 132.2, $132.1\left(\mathrm{q},{ }^{2} \mathrm{~J}(\mathrm{C}, \mathrm{F})=33.2 \mathrm{~Hz}\right), 131.7,131.1,130.8,130.3,129.4,129.0,128.9$, $128.4,128.3,127.7,127.6,127.4,127.3,127.3,127.0,126.9,125.8,125.6$, $124.6,123.8\left(\mathrm{q},{ }^{1} J(\mathrm{C}, \mathrm{F})=272.7 \mathrm{~Hz}\right), 123.2,122.2,122.0,119.6,117.2,67.1$ $\left(\mathrm{d}, \quad{ }^{2} J(\mathrm{C}, \mathrm{P})=6.5 \mathrm{~Hz}\right), \quad 44.3 \mathrm{ppm} ;{ }^{31} \mathrm{P} \mathrm{NMR} \quad\left(162 \mathrm{MHz}, \quad \mathrm{CD}_{2} \mathrm{Cl}_{2}\right): \quad \delta=$ $140.6 \mathrm{ppm}$ (s); ${ }^{19} \mathrm{~F}$ NMR (282 MHz, $\left.\mathrm{CD}_{2} \mathrm{Cl}_{2}\right): \delta=-62.2 \mathrm{ppm}$ (s); IR (film): $\tilde{v}=3219.2,1635.3,1382.7,1281.0,1230.0,823.5 \mathrm{~cm}^{-1}$; HRMS (ESI+): $m / z$ calcd for $\mathrm{C}_{44} \mathrm{H}_{29} \mathrm{~F}_{6} \mathrm{~N}_{2} \mathrm{O}_{5} \mathrm{PNa}$ : $833.16105[M+\mathrm{Na}]^{+}$; found: 833.16280 .

\section{$N^{1}$-(4-Butylphenyl)- $N^{2}$-(3-((11bS)-dinaphtho[2,1-d:1', $\left.2^{\prime}-f\right][1,3,2]$ dioxa-}

phosphepin-4-yloxy)phenyl)phthalamide $\mathbf{4 j}$ : The product was prepared according to the general procedure 1 starting from $(S)$-binol- $\mathrm{PCl}$ $(0.351 \mathrm{~g})$ and alcohol $3 \mathbf{j}(0.223 \mathrm{~g})$ in the presence of $\mathrm{Et}_{3} \mathrm{~N}(0.24 \mathrm{~mL}) . \mathrm{Pu}-$ rification by flash chromatography on silica gel $\left(\mathrm{CH}_{2} \mathrm{Cl}_{2}\right.$ and then 95:5 $\left.\mathrm{CH}_{2} \mathrm{Cl}_{2} / \mathrm{Et}_{2} \mathrm{O}\right)$ gave the product as a white solid. Yield: $0.245 \mathrm{~g}(61 \%)$; m.p. ${ }^{158}-164^{\circ} \mathrm{C} ;[\alpha]_{\mathrm{D}}^{20}=+101.8\left(c=1.0\right.$ in $\left.\mathrm{CH}_{2} \mathrm{Cl}_{2}\right) ;{ }^{1} \mathrm{H} \mathrm{NMR}(400 \mathrm{MHz}$, $\left.\mathrm{CD}_{2} \mathrm{Cl}_{2}\right): \delta=9.17(\mathrm{~s}, 1 \mathrm{H}), 8.58(\mathrm{~s}, 1 \mathrm{H}), 8.03\left(\mathrm{~d},{ }^{3} J(\mathrm{H}, \mathrm{H})=8.8 \mathrm{~Hz}, 1 \mathrm{H}\right)$, $7.98\left(\mathrm{~d},{ }^{3} J(\mathrm{H}, \mathrm{H})=8.2 \mathrm{~Hz}, 1 \mathrm{H}\right), 7.91\left(\mathrm{~d},{ }^{3} J(\mathrm{H}, \mathrm{H})=8.6 \mathrm{~Hz}, 2 \mathrm{H}\right), 7.71-7.67$ $(\mathrm{m}, 2 \mathrm{H}), 7.62(\mathrm{~m}, 1 \mathrm{H}), 7.58\left(\mathrm{~d},{ }^{3} \mathrm{~J}(\mathrm{H}, \mathrm{H})=8.8 \mathrm{~Hz}, 1 \mathrm{H}\right), 7.52\left(\mathrm{~d},{ }^{3} \mathrm{~J}(\mathrm{H}, \mathrm{H})=\right.$ $8.4 \mathrm{~Hz}, 2 \mathrm{H}), 7.49-7.42(\mathrm{~m}, 5 \mathrm{H}), 7.38-7.24(\mathrm{~m}, 6 \mathrm{H}), 7.12\left(\mathrm{~d},{ }^{3} J(\mathrm{H}, \mathrm{H})=\right.$ $8.3 \mathrm{~Hz}, 2 \mathrm{H}), 6.92\left(\mathrm{dd},{ }^{3} J(\mathrm{H}, \mathrm{H})=8.0 \mathrm{~Hz},{ }^{4} J(\mathrm{H}, \mathrm{H})=2.2 \mathrm{~Hz}, 1 \mathrm{H}\right), 2.54\left(\mathrm{t},{ }^{3} J-\right.$ $(\mathrm{H}, \mathrm{H})=7.6 \mathrm{~Hz}, 2 \mathrm{H}), 1.53(\mathrm{~m}, 2 \mathrm{H}), 1,30(\mathrm{~m}, 2 \mathrm{H}), 0.89 \mathrm{ppm}\left(\mathrm{t},{ }^{3} J(\mathrm{H}, \mathrm{H})=\right.$ $7.3 \mathrm{~Hz}, 3 \mathrm{H}) ;{ }^{13} \mathrm{C}$ NMR $\left(100 \mathrm{MHz}, \mathrm{CD}_{2} \mathrm{Cl}_{2}\right): \delta=168.4,168.1,151.8,148.0$, $147.5,140.7,139.1,136.9,135.5,134.8,133.2,132.9,132.2,131.8,131.0$, $130.5,130.2,129.8,129.0,129.0,128.7,128.5,127.3,127.2,126.8,125.8$, $125.5,124.8,123.3,122.3,122.2,120.5,116.9,116.2,112.4,35.6,34.3,23.0$, $14.3 \mathrm{ppm} ;{ }^{31} \mathrm{P}$ NMR $\left(162 \mathrm{MHz}, \mathrm{CD}_{2} \mathrm{Cl}_{2}\right): \delta=145.8 \mathrm{ppm}$ (s); IR (film): $\tilde{v}=$ 3238.9, 3064.3, 2954.4, 1642.1, 1541.8, 1412.6, 1326.8, 1228.4, 824.4 cm $\mathrm{cm}^{-1}$; HRMS (ESI+: $m / z$ calcd for $\mathrm{C}_{44} \mathrm{H}_{35} \mathrm{~N}_{2} \mathrm{NaO}_{5} \mathrm{P}: 725.21813[M+\mathrm{Na}]^{+}$; found: 725.21637 .

$N^{1}$-(4-Butylphenyl)- $N^{2}$-(4-((11bS)-dinaphtho[2,1-d:1',2'-f][1,3,2]dioxaphosphepin-4-yloxy)phenyl)phthalamide $4 \mathrm{k}$ : The product was prepared according to the general procedure 1 starting from $(S)$-binol-PCl $(0.861 \mathrm{~g})$ and alcohol $3 \mathbf{k}(0.778 \mathrm{~g})$ in the presence of $\mathrm{Et}_{3} \mathrm{~N}(0.93 \mathrm{~mL}) . \mathrm{Pu}-$ rification by flash chromatography on silica gel $\left(\mathrm{CH}_{2} \mathrm{Cl}_{2}\right.$ and then 95:5 $\left.\mathrm{CH}_{2} \mathrm{Cl}_{2} / \mathrm{Et}_{2} \mathrm{O}\right)$ gave the product as a yellow solid. Yield: $0.927 \mathrm{~g}(60 \%)$; m.p. $140-145^{\circ} \mathrm{C} ;[\alpha]_{\mathrm{D}}^{20}=+51.4\left(c=1.0\right.$ in $\left.\mathrm{CH}_{2} \mathrm{Cl}_{2}\right) ;{ }^{1} \mathrm{H} \mathrm{NMR}(400 \mathrm{MHz}$, $\left.\mathrm{CD}_{2} \mathrm{Cl}_{2}\right): \delta=9.21(\mathrm{~s}, 1 \mathrm{H}), 8.75(\mathrm{~s}, 1 \mathrm{H}), 8.00\left(\mathrm{~d},{ }^{3} J(\mathrm{H}, \mathrm{H})=8.8 \mathrm{~Hz}, 1 \mathrm{H}\right)$, $7.97\left(\mathrm{~d},{ }^{3} J(\mathrm{H}, \mathrm{H})=8.4 \mathrm{~Hz}, 1 \mathrm{H}\right), 7.94\left(\mathrm{~d},{ }^{3} J(\mathrm{H}, \mathrm{H})=8.9 \mathrm{~Hz}, 1 \mathrm{H}\right), 7.92\left(\mathrm{~d},{ }^{3} J-\right.$ $(\mathrm{H}, \mathrm{H})=8.2 \mathrm{~Hz}, 1 \mathrm{H}), 7.62\left(\mathrm{~d},{ }^{3} \mathrm{~J}(\mathrm{H}, \mathrm{H})=8.8 \mathrm{~Hz}, 2 \mathrm{H}\right), 7.57-7.26(\mathrm{~m}, 16 \mathrm{H})$ $7.13(\mathrm{~m}, 4 \mathrm{H}), 2.6\left(\mathrm{t},{ }^{3} \mathrm{~J}(\mathrm{H}, \mathrm{H})=7.7 \mathrm{~Hz}, 2 \mathrm{H}\right), 1.57(\mathrm{~m}, 2 \mathrm{H}), 1.32(\mathrm{~m}, 2 \mathrm{H})$, $0.91 \mathrm{ppm}\left(\mathrm{t},{ }^{3} J(\mathrm{H}, \mathrm{H})=7.3 \mathrm{~Hz}, 3 \mathrm{H}\right) ;{ }^{13} \mathrm{C} \mathrm{NMR}\left(100 \mathrm{MHz}, \mathrm{CD}_{2} \mathrm{Cl}_{2}\right): \delta=$ $168.2,168.1,148.1,148.0,147.6,139.3,136.9,136.2,135.6,135.4,133.3$, $133.0,132.3,131.8,131.0,130.5,130.2,130.1,129.0,128.8,128.5,128.4$ $127.4,127.2$, 126.9, 126.8, 125.8, 125.6, 124.8, 123.4, 122.3, 122.0, 120.6 35.7, 34.3, 23.0, $14.3 \mathrm{ppm} ;{ }^{31} \mathrm{P}$ NMR (162 $\left.\mathrm{MHz}, \mathrm{CD}_{2} \mathrm{Cl}_{2}\right): \delta=146.2 \mathrm{ppm}$; IR (film): $\tilde{v}=3067.2,2954.4,1640.2,1540.9,1410.7,1328.7,1202.4$, $826.3 \mathrm{~cm}^{-1}$; HRMS (ESI+): $\mathrm{m} / z$ calcd for $\mathrm{C}_{44} \mathrm{H}_{35} \mathrm{~N}_{2} \mathrm{O}_{5} \mathrm{P}: 725.21813$ $[M+\mathrm{Na}]^{+}$; found: 725.21599 .

$N^{1}$-(4-Butylphenyl)- $N^{2}$-(7-((11bS)-dinaphtho[2,1- $\left.d: 1^{\prime}, 2^{\prime}-f\right][1,3,2]$ dioxaphosphepin-4-yloxy)naphthalen-1-yl)phthalamide 41: The product was prepared according to the general procedure 1 starting from $(S)$-binol$\mathrm{PCl}(0.190 \mathrm{~g})$ and alcohol $3 \mathrm{I}(0.238 \mathrm{~g})$ in the presence of $\mathrm{Et}_{3} \mathrm{~N}(0.23 \mathrm{~mL})$. Purification by flash chromatography on silica gel $\left(\mathrm{CH}_{2} \mathrm{Cl}_{2}\right.$ and then $95: 5$ $\left.\mathrm{CH}_{2} \mathrm{Cl}_{2} / \mathrm{EtOAc}\right)$ gave the product as a white solid. Yield: $0.271 \mathrm{~g}(67 \%)$; m.p. ${ }^{150}-160^{\circ} \mathrm{C} ;[\alpha]_{\mathrm{D}}^{20}=+76.5\left(c=1.0\right.$ in $\left.\mathrm{CH}_{2} \mathrm{Cl}_{2}\right) ;{ }^{1} \mathrm{H} \mathrm{NMR}(400 \mathrm{MHz}$, $\left.\mathrm{CD}_{2} \mathrm{Cl}_{2}\right): \delta=8.62(\mathrm{~s}, 1 \mathrm{H}), 8.46(\mathrm{~s}, 1 \mathrm{H}), 8.05\left(\mathrm{~d},{ }^{3} J(\mathrm{H}, \mathrm{H})=8.8 \mathrm{~Hz}, 1 \mathrm{H}\right)$, $7.99\left(\mathrm{~d},{ }^{3} J(\mathrm{H}, \mathrm{H})=8.3 \mathrm{~Hz}, 1 \mathrm{H}\right), 7.89-7.72(\mathrm{~m}, 7 \mathrm{H}), 7.60\left(\mathrm{~d},{ }^{3} J(\mathrm{H}, \mathrm{H})=\right.$ $8.8 \mathrm{~Hz}, 1 \mathrm{H}), 7.57-7.22(\mathrm{~m}, 12 \mathrm{H}), 7.49\left(\mathrm{~d},{ }^{3} \mathrm{~J}(\mathrm{H}, \mathrm{H})=8.2 \mathrm{~Hz}, 2 \mathrm{H}\right), 7.07(\mathrm{~d}$, $\left.{ }^{3} J(\mathrm{H}, \mathrm{H})=8.2 \mathrm{~Hz}, 2 \mathrm{H}\right), 2.51\left(\mathrm{t},{ }^{3} J(\mathrm{H}, \mathrm{H})=7.7 \mathrm{~Hz}, 2 \mathrm{H}\right), 1.51(\mathrm{~m}, 2 \mathrm{H}), 1.3$ $(\mathrm{m}, 2 \mathrm{H}), 0.88 \mathrm{ppm}(\mathrm{m}, 3 \mathrm{H}) ;{ }^{13} \mathrm{C} \mathrm{NMR}\left(100 \mathrm{MHz}, \mathrm{CD}_{2} \mathrm{Cl}_{2}\right): \delta=168.6$, $167.6,150.8,148.5,147.6,140.2,136.1,135.8,135.6,133.4,133.0,132.7$, $132.4,131.9,131.9,131.8,131.2,130.5,129.6,129.4,129.1,129.0,127.4$, $127.2,127.1,126.9,127.0,125.9,125.7,125.4,124.9,123.2,122.3,122.3$, 121.7, 120.8, 111.8, 111.7, 35.6, 34.2, 22.9, 14.3 ppm; ${ }^{31} \mathrm{P}$ NMR (162 MHz, $\left.\mathrm{CD}_{2} \mathrm{Cl}_{2}\right): \delta=144.3 \mathrm{ppm}$; IR (film): $\tilde{v}=3247.5,3057.6,2954.4,1644.0$, 1538.0, 1411.6, 1328.7, 1229.4, 825.4 $\mathrm{cm}^{-1}$; HRMS (ESI+): $\mathrm{m} / \mathrm{z}$ calcd for $\mathrm{C}_{48} \mathrm{H}_{37} \mathrm{~N}_{2} \mathrm{NaO}_{5} \mathrm{P}$ : $775.23378[M+\mathrm{Na}]^{+}$; found: 775.23122 .

$N^{1}$-Butyl- $N^{\mathbf{2}}$-(3-((11bS)-dinaphtho[2,1-d:1', $\left.\mathbf{2}^{\prime}-f\right][1,3,2]$ dioxaphosphepin-4loxy)phenyl)phthalamide $4 \mathrm{~m}$ : The product was prepared according to the general procedure 1 starting from $(S)$-binol-PCl $(0.225 \mathrm{~g})$ and alcohol $3 \mathbf{m}(0.200 \mathrm{~g})$ in the presence of $\mathrm{Et}_{3} \mathrm{~N}(0.27 \mathrm{~mL})$. Purification by flash chromatography on silica gel $\left(\mathrm{CH}_{2} \mathrm{Cl}_{2}\right.$ and then 98:2 to $9: 1 \mathrm{CH}_{2} \mathrm{Cl}_{2} /$ EtOAc) gave the product as a white solid. Yield: $0.202 \mathrm{~g}(50 \%)$; m.p. $163-170^{\circ} \mathrm{C} ; \quad[\alpha]_{\mathrm{D}}^{20}=+83.8 \quad\left(c=1.0\right.$ in $\left.\mathrm{CH}_{2} \mathrm{Cl}_{2}\right) ;{ }^{1} \mathrm{H} \mathrm{NMR} \quad(400 \mathrm{MHz}$, $\left.\mathrm{CD}_{2} \mathrm{Cl}_{2}\right): \delta=9.61(\mathrm{~s}, 1 \mathrm{H}), 8.05\left(\mathrm{~d},{ }^{3} J(\mathrm{H}, \mathrm{H})=8.8 \mathrm{~Hz}, 1 \mathrm{H}\right), 8.00\left(\mathrm{~d},{ }^{3} J-\right.$ $(\mathrm{H}, \mathrm{H})=8.8 \mathrm{~Hz}, 1 \mathrm{H}), 7.99-7.95(\mathrm{~m}, 2 \mathrm{H}), 7.87\left(\mathrm{~d},{ }^{3} J(\mathrm{H}, \mathrm{H})=7.1 \mathrm{~Hz}, 1 \mathrm{H}\right)$, $7.74(\mathrm{~s}, 1 \mathrm{H}), 7.61\left(\mathrm{~d},{ }^{3} J(\mathrm{H}, \mathrm{H})=8.8 \mathrm{~Hz}, 1 \mathrm{H}\right), 7.57-7.43(\mathrm{~m}, 6 \mathrm{H}), 7.39-7.26$ $(\mathrm{m}, 6 \mathrm{H}), 6.96\left(\mathrm{~d},{ }^{3} J(\mathrm{H}, \mathrm{H})=7.9 \mathrm{~Hz}, 1 \mathrm{H}\right), 6.34(\mathrm{~s}, 1 \mathrm{H}), 3.41\left(\mathrm{q},{ }^{3} J(\mathrm{H}, \mathrm{H})=\right.$ $6.9 \mathrm{~Hz}, 2 \mathrm{H}), 1.52(\mathrm{~m}, 2 \mathrm{H}), 1.31(\mathrm{~m}, 2 \mathrm{H}), 0.85 \mathrm{ppm}\left(\mathrm{t},{ }^{3} J(\mathrm{H}, \mathrm{H})=7.3 \mathrm{~Hz}\right.$ $3 \mathrm{H}) ;{ }^{13} \mathrm{C}$ NMR $\left(100 \mathrm{MHz}, \mathrm{CD}_{2} \mathrm{Cl}_{2}\right): \delta=170.6,166.9,152.4,148.1,147.6$, $140.6,135.5,135.2,133.4,133.1,132.3,131.9,131.2,131.1,130.7,130.6$, $130.5,130.1,129.0,128.2,127.4,127.3,127.0,126.9,125.9,125.7,124.9$, $123.4,122.3,122.2,116.6,116.5,112.7,112.6,40.6,32.0,20.6,14.0 \mathrm{ppm}$; ${ }^{31} \mathrm{P}$ NMR $\quad\left(162 \mathrm{MHz}, \quad \mathrm{CD}_{2} \mathrm{Cl}_{2}\right): \quad \delta=146.1 \mathrm{ppm} ; \quad$ IR $\quad($ film $): \quad \tilde{v}=2958.3$, 1633.9, 1547.6, 1436.7, 1324.9, 1229.4, 824.4 $\mathrm{cm}^{-1}$; HRMS (ESI+): $\mathrm{m} / \mathrm{z}$ calcd for $\mathrm{C}_{38} \mathrm{H}_{31} \mathrm{~N}_{2} \mathrm{NaO}_{5} \mathrm{P}: 649,18683[M+\mathrm{Na}]^{+}$; found: 649.18507 .

\section{$N^{1}$-(4-Butylphenyl)- $N^{2}$-(7-((11bS)-dinaphtho[2,1-d:1', $\left.\mathbf{2}^{\prime}-f\right][1,3,2]$ dioxa-} phosphepin-4-yloxy)naphthalen-2-yl)phthalamide $4 \mathbf{n}$ : The product was prepared according to the general procedure 1 starting from $(S)$-binol$\mathrm{PCl}(0.352 \mathrm{~g})$ and alcohol $3 \mathbf{n}(0.438 \mathrm{~g})$ in the presence of $\mathrm{Et}_{3} \mathrm{~N}(0.42 \mathrm{~mL})$. Purification by flash chromatography on silica gel (98:2 and then $95: 5$ $\left.\mathrm{CH}_{2} \mathrm{Cl}_{2} / \mathrm{Et}_{2} \mathrm{O}\right)$ gave the product as a white solid. Yield: $0.300 \mathrm{~g}(40 \%)$; m.p. ${ }^{170}-178^{\circ} \mathrm{C} ;[\alpha]_{\mathrm{D}}^{20}=-23.1\left(c=1.0\right.$ in $\left.\mathrm{CH}_{2} \mathrm{Cl}_{2}\right) ;{ }^{1} \mathrm{H}$ NMR $(400 \mathrm{MHz}$, $\left.\mathrm{CD}_{2} \mathrm{Cl}_{2}\right): \delta=10.48(\mathrm{~s}, 1 \mathrm{H}), 9.65(\mathrm{~s}, 1 \mathrm{H}), 8.32(\mathrm{~s}, 1 \mathrm{H}), 7.97\left(\mathrm{~d},{ }^{3} J(\mathrm{H}, \mathrm{H})=\right.$ $8.8 \mathrm{~Hz}, 1 \mathrm{H}), 7.97\left(\mathrm{~d},{ }^{3} J(\mathrm{H}, \mathrm{H})=8.0 \mathrm{~Hz}, 1 \mathrm{H}\right), 7.87\left(\mathrm{t},{ }^{3} J(\mathrm{H}, \mathrm{H})=7.3 \mathrm{~Hz}\right.$, $2 \mathrm{H}), 7.64\left(\mathrm{~d},{ }^{3} J(\mathrm{H}, \mathrm{H})=8.7 \mathrm{~Hz}, 1 \mathrm{H}\right), 7.59-7.52(\mathrm{~m}, 5 \mathrm{H}), 7.49-7.41(\mathrm{~m}$, $4 \mathrm{H}), 7.38\left(\mathrm{t},{ }^{3} J(\mathrm{H}, \mathrm{H})=7.8 \mathrm{~Hz}, 2 \mathrm{H}\right), 7.31-7.23(\mathrm{~m}, 3 \mathrm{H}), 7.11-7.02(\mathrm{~m}$, $4 \mathrm{H}), 6.94\left(\mathrm{~d},{ }^{3} J(\mathrm{H}, \mathrm{H})=8.3 \mathrm{~Hz}, 2 \mathrm{H}\right), 2.38\left(\mathrm{t},{ }^{3} J(\mathrm{H}, \mathrm{H})=7.6 \mathrm{~Hz}, 2 \mathrm{H}\right), 1.41$ $(\mathrm{m}, 2 \mathrm{H}), 1.24(\mathrm{~m}, 2 \mathrm{H}), 0.84 \mathrm{ppm}\left(\mathrm{t},{ }^{3} J(\mathrm{H}, \mathrm{H})=7.3 \mathrm{~Hz}, 3 \mathrm{H}\right) ;{ }^{13} \mathrm{C} \mathrm{NMR}$ 
$\left(100 \mathrm{MHz}, \mathrm{CD}_{2} \mathrm{Cl}_{2}\right): \delta=168.5,168.2,150.1,148.2,147.7,139.6,137.9$, 136.6, 135.8, 135.0, 133.4, 133.1, 132.4, 131.9, 131.1, 130.5, 130.4, 130.1, $129.0,128.9,128.7,128.5,128.4,128.2,127.4,127.3,127.0,126.9,125.9$, $125.7,124.9,123.5,122.3,120.6,120.1,120.0,116.5,116.4,35.5,34.1,22.9$, $14.3 \mathrm{ppm} ;{ }^{31} \mathrm{P}$ NMR $\left(162 \mathrm{MHz}, \mathrm{CD}_{2} \mathrm{Cl}_{2}\right): \delta=146.2 \mathrm{ppm}$; IR (film): $\tilde{v}=$ 3066.3, 2954.4, 1638.2, 1541.8, 1429.0, 1332.6, 1230.4, $827.3 \mathrm{~cm}^{-1}$; HRMS (ESI+: $m / z$ calcd for $\mathrm{C}_{48} \mathrm{H}_{37} \mathrm{~N}_{2} \mathrm{NaO}_{5} \mathrm{P}: 775.23378[M+\mathrm{Na}]^{+}$; found: 775.23177 .

\section{$N^{1}$-(4-Butylphenyl)- $N^{2}$-(3-((11bS)-dinaphtho[2,1-d:1', $\left.\mathbf{2}^{\prime}-f\right][1,3,2]$ dioxa-} phosphepin-4-yloxy)phenethyl)phthalamide 4o: The product was prepared according to the general procedure 2 starting from $(S)$-binol- $-\mathrm{PCl}$ $(0.253 \mathrm{~g})$ and alcohol $3 \mathrm{o}(0.300 \mathrm{~g})$ in the presence of $\mathrm{Et}_{3} \mathrm{~N}(0.30 \mathrm{~mL})$. Purification by flash chromatography on silica gel $\left(\mathrm{CH}_{2} \mathrm{Cl}_{2}\right.$ and then $98: 2$ to 95:5 $\left.\mathrm{CH}_{2} \mathrm{Cl}_{2} / \mathrm{Et}_{2} \mathrm{O}\right)$ gave the product as a white solid. Yield: $0.277 \mathrm{~g}$ $(52 \%)$; m.p. $130-143^{\circ} \mathrm{C} ;[\alpha]_{\mathrm{D}}^{20}=+150.7\left(c=1.0\right.$ in $\left.\mathrm{CH}_{2} \mathrm{Cl}_{2}\right) ;{ }^{1} \mathrm{H}$ NMR $\left(400 \mathrm{MHz}, \mathrm{CD}_{2} \mathrm{Cl}_{2}\right): \delta=9.01(\mathrm{~s}, 1 \mathrm{H}), 8.04\left(\mathrm{~d},{ }^{3} J(\mathrm{H}, \mathrm{H})=8.8 \mathrm{~Hz}, 1 \mathrm{H}\right), 7.98$ $\left(\mathrm{d},{ }^{3} \mathrm{~J}(\mathrm{H}, \mathrm{H})=8.2 \mathrm{~Hz}, 1 \mathrm{H}\right), 7.93\left(\mathrm{~d},{ }^{3} \mathrm{~J}(\mathrm{H}, \mathrm{H})=8.6 \mathrm{~Hz}, 2 \mathrm{H}\right), 7.78\left(\mathrm{~d},{ }^{3} \mathrm{~J}-\right.$ $(\mathrm{H}, \mathrm{H})=7.6 \mathrm{~Hz}, 1 \mathrm{H}), 7.57\left(\mathrm{~d},{ }^{3} J(\mathrm{H}, \mathrm{H})=8.8 \mathrm{~Hz}, 1 \mathrm{H}\right), 7.54\left(\mathrm{~d},{ }^{3} J(\mathrm{H}, \mathrm{H})=\right.$ $8.4 \mathrm{~Hz}, 2 \mathrm{H}), 7.50-7.40(\mathrm{~m}, 6 \mathrm{H}), 7.37-7.23(\mathrm{~m}, 5 \mathrm{H}), 7.16\left(\mathrm{~d},{ }^{3} \mathrm{~J}(\mathrm{H}, \mathrm{H})=\right.$ $8.4 \mathrm{~Hz}, 2 \mathrm{H}), 7.01(\mathrm{~m}, 3 \mathrm{H}), 6.37\left(\mathrm{t},{ }^{3} J(\mathrm{H}, \mathrm{H})=5.5 \mathrm{~Hz}, 1 \mathrm{H}\right), 3.60\left(\mathrm{q},{ }^{3} J-\right.$ $(\mathrm{H}, \mathrm{H})=6.9 \mathrm{~Hz}, 2 \mathrm{H}), 2.83\left(\mathrm{t},{ }^{3} J(\mathrm{H}, \mathrm{H})=7.0 \mathrm{~Hz}, 2 \mathrm{H}\right), 2.58\left(\mathrm{t},{ }^{3} J(\mathrm{H}, \mathrm{H})=\right.$ $7.6 \mathrm{~Hz}, 2 \mathrm{H}), 1.58(\mathrm{~m}, 2 \mathrm{H}), 1.33(\mathrm{~m}, 2 \mathrm{H}), 0.91 \mathrm{ppm}\left(\mathrm{t},{ }^{3} \mathrm{~J}(\mathrm{H}, \mathrm{H})=7.3 \mathrm{~Hz}\right.$ $3 \mathrm{H}) ;{ }^{13} \mathrm{C}$ NMR $\left(100 \mathrm{MHz}, \mathrm{CD}_{2} \mathrm{Cl}_{2}\right): \delta=170.3,166.7,152.4,148.2,147.5$, $141.7,139.8,136.6,135.5,135.4,133.4,133.0,132.3,131.9,131.2,131.0$, $130.8,130.5,129.7,129.3,128.0,128.9,128.3,127.4,127.3,127.0,126.9$, $125.9,125.7,125.5,124.8,123.4,122.3,122.2,121.4,121.3,120.6,119.1$, 119.0, 41.7, 35.7, 35.6, 34.3, 22.9, $14.3 \mathrm{ppm} ;{ }^{31} \mathrm{P}$ NMR (162 MHz, $\left.\mathrm{CD}_{2} \mathrm{Cl}_{2}\right)$ : $\delta=145.4 \mathrm{ppm}$; IR (film): $\tilde{v}=3067.2,2954.4,1632.5,1540.9,1411.6,1327.8$, 1224.6, $824.4 \mathrm{~cm}^{-1}$; HRMS (ESI+): $\mathrm{m} / z$ calcd for $\mathrm{C}_{46} \mathrm{H}_{39} \mathrm{~N}_{2} \mathrm{NaO}_{5} \mathrm{P}$ : $753.24943[\mathrm{M}+\mathrm{Na}]^{+}$; found: 753.24709 .

\section{$N^{1}$-(4-Butylphenyl)- $N^{2}$-(3-((11 bS)-dinaphtho[2,1-d:1', $\left.2^{\prime}-f\right][1,3,2]$ dioxa-} phosphepin-4-yloxy)-2,2-dimethylpropyl)phthalamide $4 \mathbf{p}$ : The product was prepared according to the general procedure 1 starting from $(S)$ binol- $\mathrm{PCl}(0.183 \mathrm{~g})$ and alcohol $3 \mathbf{p}(0.200 \mathrm{~g})$ in the presence of $\mathrm{Et}_{3} \mathrm{~N}$ $(0.22 \mathrm{~mL})$. Purification by flash chromatography on silica gel $\left(\mathrm{CH}_{2} \mathrm{Cl}_{2}\right.$ and then 96:4 to $9: 1 \mathrm{CH}_{2} \mathrm{Cl}_{2} / \mathrm{Et}_{2} \mathrm{O}$ ) gave the product as a white solid. Yield: $0.235 \mathrm{~g}(65 \%)$; m.p. $113-125^{\circ} \mathrm{C} ;[\alpha]_{\mathrm{D}}^{20}=+381.1\left(c=1.0\right.$ in $\left.\mathrm{CH}_{2} \mathrm{Cl}_{2}\right)$; ${ }^{1} \mathrm{H}$ NMR $\left(400 \mathrm{MHz}, \mathrm{CD}_{2} \mathrm{Cl}_{2}\right): \delta=9.16(\mathrm{~s}, 1 \mathrm{H}), 7.99\left(\mathrm{~d},{ }^{3} \mathrm{~J}(\mathrm{H}, \mathrm{H})=8.8 \mathrm{~Hz}\right.$, $1 \mathrm{H}), 7.96\left(\mathrm{~d},{ }^{3} J(\mathrm{H}, \mathrm{H})=8.4 \mathrm{~Hz}, 1 \mathrm{H}\right), 7.89(\mathrm{~m}, 2 \mathrm{H}), 7.75\left(\mathrm{~d},{ }^{3} J(\mathrm{H}, \mathrm{H})=\right.$ $7.5 \mathrm{~Hz}, 1 \mathrm{H}), 7.50\left(\mathrm{~d},{ }^{3} \mathrm{~J}(\mathrm{H}, \mathrm{H})=7.3 \mathrm{~Hz}, 2 \mathrm{H}\right), 7.45-7.37(\mathrm{~m}, 5 \mathrm{H}), 7.31-7.26$ $(\mathrm{m}, 5 \mathrm{H}), 7.18\left(\mathrm{t},{ }^{3} J(\mathrm{H}, \mathrm{H})=7.5 \mathrm{~Hz}, 1 \mathrm{H}\right), 7.13\left(\mathrm{~d},{ }^{3} \mathrm{~J}(\mathrm{H}, \mathrm{H})=7.3 \mathrm{~Hz}, 2 \mathrm{H}\right)$, $6.56\left(\mathrm{t},{ }^{3} J(\mathrm{H}, \mathrm{H})=5.5 \mathrm{~Hz}, 1 \mathrm{H}\right), 3.77(\mathrm{~m}, 1 \mathrm{H}), 3.57\left(\mathrm{dd},{ }^{2} J(\mathrm{H}, \mathrm{H})=10.2 \mathrm{~Hz}\right.$, $\left.{ }^{3} \mathrm{~J}(\mathrm{H}, \mathrm{P})=6.0 \mathrm{~Hz} 1 \mathrm{H}\right), 3.29\left(\mathrm{~d},{ }^{3} \mathrm{~J}(\mathrm{H}, \mathrm{H})=6.3 \mathrm{~Hz}, 2 \mathrm{H}\right), 2.57\left(\mathrm{t},{ }^{3} \mathrm{~J}(\mathrm{H}, \mathrm{H})=\right.$ $7.6 \mathrm{~Hz}, 2 \mathrm{H}), 1.58(\mathrm{~m}, 2 \mathrm{H}), 1.34(\mathrm{~m}, 2 \mathrm{H}), 0.94-0.90(\mathrm{~m}, 6 \mathrm{H}), 0.86 \mathrm{ppm}(\mathrm{s}$, $3 \mathrm{H}) ;{ }^{13} \mathrm{C}$ NMR $\left(100 \mathrm{MHz}, \mathrm{CD}_{2} \mathrm{Cl}_{2}\right): \delta=170.4,168.8,147.8,139.4,136.7$, $135.7,135.3,133.3,133.0,132.2,131.6,131.0,130.7,130.6,130.5,129.6$, $129.1,129.0,128.0,127.3,127.2,126.9,125.7,125.5,124.6,123.1,122.2$, 122.1, 121.4, 120.6, $72.4\left(\mathrm{~d},{ }^{2} J(\mathrm{C}, \mathrm{P})=5.4 \mathrm{~Hz}\right), 47.5,36.9,35.6,34.3,22.9$, 22.7, 22.6, $14.3 \mathrm{ppm} ;{ }^{31} \mathrm{P}$ NMR $\left(162 \mathrm{MHz}, \mathrm{CD}_{2} \mathrm{Cl}_{2}\right): \delta=143.0 \mathrm{ppm}$; IR (film): $\tilde{v}=3112.6,3056.6,2955.4,1631.5,1540.9,1438.6,1329.7,1231.3$, $825.4 \mathrm{~cm}^{-1}$; HRMS (ESI+): $\mathrm{m} / z$ calcd for $\mathrm{C}_{43} \mathrm{H}_{41} \mathrm{~N}_{2} \mathrm{NaO}_{5} \mathrm{P}$ : 719.26508 $[M+\mathrm{Na}]^{+}$; found: 719.26346 .

\section{$N^{1}$-(4-Butylphenyl)- $N^{2}$-(2-(((11 bS)-dinaphtho[2,1-d:1', $\mathbf{2}^{\prime}-f[[1,3,2]$ dioxa-} phosphepin-4-yloxy)methyl)phenethyl)phthalamide 4q: The product was prepared according to the general procedure 2 starting from $(S)$-binol$\mathrm{PCl}(0.326 \mathrm{~g})$ and alcohol $3 \mathbf{q}(0.400 \mathrm{~g})$ in the presence of $\mathrm{Et}_{3} \mathrm{~N}(0.39 \mathrm{~mL})$. Purification by flash chromatography on silica gel $\left(\mathrm{CH}_{2} \mathrm{Cl}_{2}\right.$, then $95: 5$ to 9:1 $\mathrm{CH}_{2} \mathrm{Cl}_{2} / \mathrm{EtOAc}$ ) gave the product as a white solid. Yield: $0.503 \mathrm{~g}$ (71\%); m.p. $125-130^{\circ} \mathrm{C} ;[\alpha]_{\mathrm{D}}^{20}=+298.4\left(c=1.0\right.$ in $\left.\mathrm{CH}_{2} \mathrm{Cl}_{2}\right) ;{ }^{1} \mathrm{H}$ NMR $\left(400 \mathrm{MHz}, \mathrm{CD}_{2} \mathrm{Cl}_{2}\right): \delta=9.23(\mathrm{~s}, 1 \mathrm{H}), 8.00\left(\mathrm{~d},{ }^{3} J(\mathrm{H}, \mathrm{H})=8.8 \mathrm{~Hz}, 1 \mathrm{H}\right), 7.96$ $\left(\mathrm{d},{ }^{3} J(\mathrm{H}, \mathrm{H})=8.2 \mathrm{~Hz}, 1 \mathrm{H}\right), 7.89\left(\mathrm{~d},{ }^{3} J(\mathrm{H}, \mathrm{H})=8.8 \mathrm{~Hz}, 1 \mathrm{H}\right), 7.84\left(\mathrm{~d},{ }^{3} J-\right.$ $(\mathrm{H}, \mathrm{H})=8.2 \mathrm{~Hz}, 1 \mathrm{H}), 7.69\left(\mathrm{~d},{ }^{3} J(\mathrm{H}, \mathrm{H})=7.7 \mathrm{~Hz}, 1 \mathrm{H}\right), 7.52\left(\mathrm{~d},{ }^{3} J(\mathrm{H}, \mathrm{H})=\right.$ $8.4 \mathrm{~Hz}, 2 \mathrm{H}), 7.48-7.43(\mathrm{~m}, 2 \mathrm{H}), 7.40-7.34(\mathrm{~m}, 2 \mathrm{H}), 7.31-7.26(\mathrm{~m}, 6 \mathrm{H})$, 7.25-7.17 (m, 5H), $7.11\left(\mathrm{~d},{ }^{3} J(\mathrm{H}, \mathrm{H})=8.4 \mathrm{~Hz}, 2 \mathrm{H}\right), 6.45\left(\mathrm{t},{ }^{3} J(\mathrm{H}, \mathrm{H})=\right.$ $5.7 \mathrm{~Hz}, 1 \mathrm{H}), 5.01\left(\mathrm{dd},{ }^{2} J(\mathrm{H}, \mathrm{H})=12.1 \mathrm{~Hz},{ }^{3} J(\mathrm{H}, \mathrm{P})=7.4 \mathrm{~Hz}, 1 \mathrm{H}\right), 4.84(\mathrm{dd}$, $\left.{ }^{2} J(\mathrm{H}, \mathrm{H})=12.1 \mathrm{~Hz},{ }^{3} J(\mathrm{H}, \mathrm{P})=7.8 \mathrm{~Hz}, 1 \mathrm{H}\right), 3.50-3.32(\mathrm{~m}, 2 \mathrm{H}), 2.78\left(\mathrm{td},{ }^{3} J-\right.$ $\left.(\mathrm{H}, \mathrm{H})=7.5 \mathrm{~Hz},{ }^{3} J(\mathrm{H}, \mathrm{H})=1.7 \mathrm{~Hz}, 2 \mathrm{H}\right), 2.56\left(\mathrm{t},{ }^{3} \mathrm{~J}(\mathrm{H}, \mathrm{H})=7.6 \mathrm{~Hz}, 2 \mathrm{H}\right)$, $1.56(\mathrm{~m}, 2 \mathrm{H}), 1.33(\mathrm{~m}, 2 \mathrm{H}), 0.91 \mathrm{ppm}\left(\mathrm{t},{ }^{3} J(\mathrm{H}, \mathrm{H})=7.3 \mathrm{~Hz}, 3 \mathrm{H}\right)$;
${ }^{13} \mathrm{C}$ NMR $\left(100 \mathrm{MHz}, \mathrm{CD}_{2} \mathrm{Cl}_{2}\right): \delta=170.4,166.6,149.2,148.0,139.7,138.1$, 136.6, 135.8, 135.5, 135.3, 133.3, 133.1, 132.2, 131.1, 131.0, 130.8, 130.7 $130.5,130.1,129.9,129.3,129.0,128.9,128.3,127.7,127.4,127.3,126.9$, $125.7,125.6,124.7,124.5,124.4,123.2,122.3,122.1,120.6,118.4,65.4$, 41.4, 35.6, 34.3, 32.4, 22.9, $14.3 \mathrm{ppm} ;{ }^{31} \mathrm{P}$ NMR $\left(162 \mathrm{MHz}, \mathrm{CD}_{2} \mathrm{Cl}_{2}\right): \delta=$ 142.4 ppm; IR (film): $\tilde{v}=3066.3,2954.4,1633.4,1539.9,1432.9,1326.8$, 1230.4, 824.4 $\mathrm{cm}^{-1}$; HRMS (ESI+): $\mathrm{m} / \mathrm{z}$ calcd for $\mathrm{C}_{47} \mathrm{H}_{41} \mathrm{~N}_{2} \mathrm{NaO}_{5} \mathrm{P}$ : $767.26508[M+\mathrm{Na}]^{+}$; found: 767.26290 .

$N^{1}$-(4-Butylphenyl)- $N^{2}-\left(3-\left(\left(\left((11 b R)-2,6-d i m e t h y l d i n a p h t h o\left[2,1-d: 1^{\prime}, 2^{\prime}-f\right]-\right.\right.\right.\right.$ $[1,3,2]$ dioxaphosphepin-4-yl)oxy)methyl)phenyl)phthalamide $4 \mathrm{r}$ : The product was prepared according to the general procedure 1 starting from $(R)-3,3^{\prime}$-dimethyl-binol-PCl $(0.283 \mathrm{~g})$ and alcohol 3r $(0.300 \mathrm{~g})$ in the presence of $\mathrm{Et}_{3} \mathrm{~N}(0.32 \mathrm{~mL})$. Purification by flash chromatography on silica gel $\left(8: 2 \mathrm{CH}_{2} \mathrm{Cl}_{2} / n\right.$-hexane, then $\mathrm{CH}_{2} \mathrm{Cl}_{2}$, then 98:2 to 9:1 $\mathrm{CH}_{2} \mathrm{Cl}_{2} /$ $\left.\mathrm{Et}_{2} \mathrm{O}\right)$ gave the product as a white solid. Yield: $0.260 \mathrm{~g}(47 \%)$; m.p. 129 $133^{\circ} \mathrm{C} ;[\alpha]_{\mathrm{D}}^{20}=-322.5\left(c=1.0\right.$ in $\left.\mathrm{CH}_{2} \mathrm{Cl}_{2}\right) ;{ }^{1} \mathrm{H}$ NMR $\left(400 \mathrm{MHz}, \mathrm{CD}_{2} \mathrm{Cl}_{2}\right)$ : $\delta=8.94(\mathrm{~s}, 1 \mathrm{H}), 8.59(\mathrm{~s}, 1 \mathrm{H}), 7.87\left(\mathrm{~d},{ }^{3} \mathrm{~J}(\mathrm{H}, \mathrm{H})=8.7 \mathrm{~Hz}, 1 \mathrm{H}\right), 7.85(\mathrm{~s}, 1 \mathrm{H})$, $7.83\left(\mathrm{~d},{ }^{3} \mathrm{~J}(\mathrm{H}, \mathrm{H})=9.0 \mathrm{~Hz}, 1 \mathrm{H}\right), 7.81(\mathrm{~s}, 1 \mathrm{H}), 7.65-7.61(\mathrm{~m}, 2 \mathrm{H}), 7.54(\mathrm{~s}$, $1 \mathrm{H}), 7.52-7.47(\mathrm{~m}, 5 \mathrm{H}), 7.42-7.35(\mathrm{~m}, 2 \mathrm{H}), 7.26-7.15(\mathrm{~m}, 5 \mathrm{H}), 7.10(\mathrm{~d}$, $\left.{ }^{3} J(\mathrm{H}, \mathrm{H})=8.2 \mathrm{~Hz}, 2 \mathrm{H}\right), 6.99\left(\mathrm{~d},{ }^{3} J(\mathrm{H}, \mathrm{H})=7.6 \mathrm{~Hz}, 1 \mathrm{H}\right), 4.95\left(\mathrm{dd},{ }^{2} J-\right.$ $\left.(\mathrm{H}, \mathrm{H})=12.2 \mathrm{~Hz},{ }^{3} J(\mathrm{H}, \mathrm{P})=8.2 \mathrm{~Hz}, 1 \mathrm{H}\right), 4.55\left(\mathrm{dd},{ }^{2} J(\mathrm{H}, \mathrm{H})=12.2 \mathrm{~Hz},{ }^{3} J-\right.$ $(\mathrm{H}, \mathrm{P})=6.7 \mathrm{~Hz}, 1 \mathrm{H}), 2.60(\mathrm{~s}, 3 \mathrm{H}), 2.54\left(\mathrm{t},{ }^{3} \mathrm{~J}(\mathrm{H}, \mathrm{H})=7.6 \mathrm{~Hz}, 2 \mathrm{H}\right), 2.51(\mathrm{~s}$, $3 \mathrm{H}), 1.50(\mathrm{~m}, 2 \mathrm{H}), 1.30(\mathrm{~m}, 2 \mathrm{H}), 0.90 \mathrm{ppm}\left(\mathrm{t},{ }^{3} \mathrm{~J}(\mathrm{H}, \mathrm{H})=7.3 \mathrm{~Hz}, 3 \mathrm{H}\right)$; ${ }^{13} \mathrm{C}$ NMR $\left(100 \mathrm{MHz}, \mathrm{CD}_{2} \mathrm{Cl}_{2}\right): \delta=167.8,167.6,148.9,147.5,140.0,138.9$, 138.6, 136.1, 135.6, 135.5, 132.2, 132.0, 132.0, 131.6, 131.1, 130.9, 130.4, $129.5,129.3,129.2,128.8,128.2,127.2,127.1,125.8,125.6,125.4,124.6$, 124.0, 123.2, 120.7, 120.2, 119.6, 66.9, 35.5, 34.2, 22.8, 18.1, 17.8, $14.3 \mathrm{ppm}$; ${ }^{31} \mathrm{P} N M R \quad\left(162 \mathrm{MHz}, \mathrm{CD}_{2} \mathrm{Cl}_{2}\right): \quad \delta=138.1 \mathrm{ppm} ; \quad$ IR $\quad($ film): $\tilde{v}=3283.2$ 3068.2, 2953.5, 1641.1, 1541.8, 1443.5, 1331.6, 1241.0, 905.4, $787.2 \mathrm{~cm}^{-1}$ HRMS (ESI+): $m / z$ calcd for $\mathrm{C}_{47} \mathrm{H}_{41} \mathrm{~N}_{2} \mathrm{NaO}_{5} \mathrm{P}: 767.26508[M+\mathrm{Na}]^{+}$; found: 767.26263 .

$N^{1}$-(4-Butylphenyl)- $N^{2}-\left(3-\left(\left(\left((11 b R)-2,6-d i m e t h y l d i n a p h t h o\left[2,1-d: 1^{\prime}, 2^{\prime}-f\right]-\right.\right.\right.\right.$ $[1,3,2]$ dioxaphosphepin-4-yl)oxy)methyl)benzyl)phthalamide $4 \mathrm{~s}$ : The product was prepared according to the general procedure 2 starting from $(R)$-3,3'-dimethyl-binol-PCl $(0.300 \mathrm{~g})$ and alcohol 3s $(0.300 \mathrm{~g})$ in the presence of $\mathrm{Et}_{3} \mathrm{~N}(0.30 \mathrm{~mL})$. Purification by flash chromatography on silica gel $\left(\mathrm{CH}_{2} \mathrm{Cl}_{2}\right.$ and then $\left.98: 2 \mathrm{CH}_{2} \mathrm{Cl}_{2} / \mathrm{Et}_{2} \mathrm{O}\right)$ gave the product as a white solid. Yield: $0.336 \mathrm{~g}(62 \%)$; m.p. $112-120^{\circ} \mathrm{C} ;[\alpha]_{\mathrm{D}}^{20}=-326.4(c=1.0$ in $\left.\mathrm{CH}_{2} \mathrm{Cl}_{2}\right) ;{ }^{1} \mathrm{H}$ NMR $\left(400 \mathrm{MHz}, \mathrm{CD}_{2} \mathrm{Cl}_{2}\right): \delta=8.75(\mathrm{~s}, 1 \mathrm{H}), 7.87\left(\mathrm{~d},{ }^{3} \mathrm{~J}-\right.$ $(\mathrm{H}, \mathrm{H})=8.4 \mathrm{~Hz}, 1 \mathrm{H}), 7.86(\mathrm{~s}, 1 \mathrm{H}), 7.80(\mathrm{~s}, 1 \mathrm{H}), 7.79\left(\mathrm{~d},{ }^{3} \mathrm{~J}(\mathrm{H}, \mathrm{H})=9.2 \mathrm{~Hz}\right.$ $2 \mathrm{H}), 7.72\left(\mathrm{~d},{ }^{3} J(\mathrm{H}, \mathrm{H})=7.3 \mathrm{~Hz}, 1 \mathrm{H}\right), 7.57-7.45(\mathrm{~m}, 3 \mathrm{H}), 7.43-7.34(\mathrm{~m}$, $4 \mathrm{H}), 7.25\left(\mathrm{~d},{ }^{3} J(\mathrm{H}, \mathrm{H})=8.4 \mathrm{~Hz}, 1 \mathrm{H}\right), 7.22-7.12(\mathrm{~m}, 7 \mathrm{H}), 7.09\left(\mathrm{~d},{ }^{3} J-\right.$ $(\mathrm{H}, \mathrm{H})=8.4 \mathrm{~Hz}, 1 \mathrm{H}), 6.90\left(\mathrm{t},{ }^{3} \mathrm{~J}(\mathrm{H}, \mathrm{H})=5.4 \mathrm{~Hz}, 1 \mathrm{H}\right), 4.84\left(\mathrm{dd},{ }^{2} J(\mathrm{H}, \mathrm{H})=\right.$ $\left.12.3 \mathrm{~Hz},{ }^{3} J(\mathrm{H}, \mathrm{P})=8.1 \mathrm{~Hz}, 1 \mathrm{H}\right), 4.59-4.46(\mathrm{~m}, 3 \mathrm{H}), 2.59(\mathrm{~s}, 3 \mathrm{H}), 2.57(\mathrm{t}$, $\left.{ }^{3} \mathrm{~J}(\mathrm{H}, \mathrm{H})=7.8 \mathrm{~Hz}, 3 \mathrm{H}\right), 2.48(\mathrm{~s}, 3 \mathrm{H}), 1.57(\mathrm{~m}, 2 \mathrm{H}), 1.34(\mathrm{~m}, 2 \mathrm{H})$, $0.92 \mathrm{ppm}\left(\mathrm{t},{ }^{3} \mathrm{~J}(\mathrm{H}, \mathrm{H})=7.3 \mathrm{~Hz}, 3 \mathrm{H}\right) ;{ }^{13} \mathrm{C} \mathrm{NMR}\left(100 \mathrm{MHz}, \mathrm{CD}_{2} \mathrm{Cl}_{2}\right): \delta=$ $169.9,167.0,148.9,147.5,139.9,138.8,138.4,136.3,135.6,135.0,132.2$, 132.0, 131.6, 131.0, 130.9, 130.5, 130.4, 129.5, 129.3, 128.7, 128.2, 127.8, $127.3,127.2,125.9,125.6,125.5,124.6,123.2,120.6,66.9\left(\mathrm{~d},{ }^{2} J(\mathrm{C}, \mathrm{P})=\right.$ $3.2 \mathrm{~Hz}), 44.4,35.6,34.3,22.9,18.0,17.8,14.3 \mathrm{ppm} ;{ }^{31} \mathrm{P}$ NMR $(162 \mathrm{MHz}$ $\mathrm{CD}_{2} \mathrm{Cl}_{2}$ ): $\delta=138.2 \mathrm{ppm}$; IR (film): $\tilde{v}=3066.3,2954.4,1637.3,1540.9$, 1412.6, 1331.6, 1240.0, 905.4, $788.7 \mathrm{~cm}^{-1}$; HRMS (ESI+): $\mathrm{m} / \mathrm{z}$ calcd for $\mathrm{C}_{48} \mathrm{H}_{43} \mathrm{~N}_{2} \mathrm{NaO}_{5} \mathrm{P}: 781.28073[M+\mathrm{Na}]^{+}$; found: 781.27897 .

$N^{1}$-(4-Butylphenyl)- $N^{2}-\left(3-\left(\left((11 b S)\right.\right.\right.$-dinaphtho[2,1- $\left.d: 1^{\prime}, 2^{\prime}-f\right][1,3,2]$ dioxaphosphepin-4-yloxy)methyl)phenyl)- $\boldsymbol{N}^{1}, \boldsymbol{N}^{2}$-dimethylphthalamide 4a-Me The product was prepared according to the general procedure 1 starting from $(S)$-binol-PCl $(0.242 \mathrm{~g})$ and alcohol 3a-Me $(0.297 \mathrm{~g})$ in the presence of $\mathrm{Et}_{3} \mathrm{~N}(0.29 \mathrm{~mL})$. Purification by flash chromatography on silica gel (98:2 and then 9:1 $\mathrm{CH}_{2} \mathrm{Cl}_{2} / \mathrm{EtOAc}$ ) gave the product as a white solid. Yield: $0.343 \mathrm{~g} \quad(66 \%) ;$ m.p. $\quad 117-123^{\circ} \mathrm{C} ; \quad\left[[\alpha]_{\mathrm{D}}^{20}=+268.0 \quad(c=1.0 \quad\right.$ in $\left.\mathrm{CH}_{2} \mathrm{Cl}_{2}\right) ;{ }^{1} \mathrm{H}$ NMR $\left(400 \mathrm{MHz}, \mathrm{CD}_{2} \mathrm{Cl}_{2}\right): \delta=8.04\left(\mathrm{~d},{ }^{3} \mathrm{~J}(\mathrm{H}, \mathrm{H})=8.8 \mathrm{~Hz}\right.$, $1 \mathrm{H}), 7.97\left(\mathrm{~d},{ }^{3} J(\mathrm{H}, \mathrm{H})=8.9 \mathrm{~Hz}, 1 \mathrm{H}\right), 7.98-7.93(\mathrm{~m}, 2 \mathrm{H}), 7.56\left(\mathrm{~d},{ }^{3} J-\right.$ $(\mathrm{H}, \mathrm{H})=8.8 \mathrm{~Hz}, 1 \mathrm{H}), 7.49-7.39(\mathrm{~m}, 4 \mathrm{H}), 7.37-7.26(\mathrm{~m}, 8 \mathrm{H}), 7.15(\mathrm{bs}$, $1 \mathrm{H}), 7.02(\mathrm{bs}, 3 \mathrm{H}), 6.82(\mathrm{bs}, 3 \mathrm{H}), 4.89(\mathrm{~m}, 1 \mathrm{H}), 4.68(\mathrm{~m}, 1 \mathrm{H}), 3.47(\mathrm{~s}$ $6 \mathrm{H}), 2.50\left(\mathrm{t},{ }^{3} \mathrm{~J}(\mathrm{H}, \mathrm{H})=6.7 \mathrm{~Hz}, 2 \mathrm{H}\right), 1.51(\mathrm{~m}, 2 \mathrm{H}), 1.31(\mathrm{~m}, 2 \mathrm{H})$ $0.90 \mathrm{ppm}(\mathrm{m}, 3 \mathrm{H}) ;{ }^{13} \mathrm{C}$ NMR $\left(100 \mathrm{MHz}, \mathrm{CD}_{2} \mathrm{Cl}_{2}\right): \delta=170.7,170.5,149.2$ $148.1,145.5,142.9,141.8,139.0,137.3,133.4,133.1,132.2,131.7,131.1$, $130.8,129.5,129.4,129.0,129.0,128.8,128.1,127.3,127.0,126.9,125.9$ 
125.7, 125.6, 124.6, 123.2, 122.3, 122.1, $66.7\left(\mathrm{~d},{ }^{2} J(\mathrm{C}, \mathrm{P})=4.4 \mathrm{~Hz}\right), 37.9$, 35.5, 34.0, 22.8, $14.3 \mathrm{ppm} ;{ }^{31} \mathrm{P}$ NMR (162 MHz, $\left.\mathrm{CD}_{2} \mathrm{Cl}_{2}\right): \delta=141.0 \mathrm{ppm}$; IR (film): $\tilde{v}=3422.1,3057.6,2929.3,1643.1,1591.0,1511.9,1430.9,1373.1$, 1325.8, 1230.4, 1020.2, 946.9, 824.4 $\mathrm{cm}^{-1}$; HRMS (ESI+): $\mathrm{m} / \mathrm{z}$ calcd for $\mathrm{C}_{47} \mathrm{H}_{41} \mathrm{~N}_{2} \mathrm{NaO}_{5} \mathrm{P}: 767.26508[M+\mathrm{Na}]^{+}$; found: 767.26311 .

General procedure for asymmetric hydrogenations under atmospheric pressure:: Each ligand $(0.0042 \mathrm{mmol}, 0.022$ equiv) was weighed and placed in one of seven oven-dried glass test tubes equipped with stirrer bars and Schlenk apparatus and subjected to three vacuum/nitrogen cycles. A solution of $\left[\mathrm{Rh}(\operatorname{cod}){ }_{2} \mathrm{BF}_{4}\right](0.9 \mathrm{~mL}, 0.001909 \mathrm{mmol}, 2.12 \mathrm{~mm}$, 0.01 equiv) in $\mathrm{CH}_{2} \mathrm{Cl}_{2}$ was added to each tube and the mixtures were stirred for 10 min under nitrogen. A solution of the substrate in $\mathrm{CH}_{2} \mathrm{Cl}_{2}$ ( $1 \mathrm{~mL}, 0.1909 \mathrm{mmol}, 0.1909 \mathrm{M}, 1$ equiv) was finally added to each tube, followed by $\mathrm{CH}_{2} \mathrm{Cl}_{2}(2.1 \mathrm{~mL})$. The reaction mixtures were subjected to three vacuum/hydrogen cycles and then left stirring overnight at room temperature under 1 bar of hydrogen. Samples were taken and analyzed for conversion and ee determination (see the Supporting Information).

General procedure for the asymmetric hydrogenation reaction at higher than atmospheric pressure: A Parr multireactor was employed that allowed six reactions to be performed in parallel under hydrogen pressure. The selected ligands $(0.0042 \mathrm{mmol}, 0.022$ equiv) were weighed in special glass vials. The vials were purged with nitrogen and a solution of [ $\mathrm{Rh}$ (cod $\left.)_{2} \mathrm{BF}_{4}\right]$ in $\mathrm{CH}_{2} \mathrm{Cl}_{2}(0.9 \mathrm{~mL}, 0.001909 \mathrm{mmol}, 2.12 \mathrm{~mm}, 0.01$ equiv) was added to each vial. After $10 \mathrm{~min}$, a solution of the substrate in $\mathrm{CH}_{2} \mathrm{Cl}_{2}$ ( $1 \mathrm{~mL}, 0.1909 \mathrm{mmol}, 0.1909 \mathrm{M}, 1$ equiv) was added followed by $\mathrm{CH}_{2} \mathrm{Cl}_{2}$ $(6.1 \mathrm{~mL})$, and the vials were placed in their respective autoclaves and purged three times with hydrogen at the selected pressure. The reactions were stirred overnight at room temperature under pressure of hydrogen, and then analyzed for conversion and ee determination (see the Supporting Information).

\section{Acknowledgements}

We thank the European Commission [RTN Network (R) Evolutionary Catalysis MRTN-CT-2006-035866] for financial support. L.P. thanks Milan University for a postdoctoral fellowship ('Assegno di ricerca'). M.C. thanks the MIUR (FIRB 'Futuro in Ricerca' RBFR088ITV) for a postdoctoral fellowship and financial support.

[1] For a comprehensive review of the topic, see: J. G. de Vries, C. J. Elseiver, Handbook of Homogeneous Hydrogenation, Wiley- $\mathrm{VCH}$, Weinheim, 2007.

[2] J. M. Hawkins, T. J. N. Watson, Angew. Chem. 2004, 116, 3286-3290; Angew. Chem. Int. Ed. 2004, 43, 3224-3228, and references therein.

[3] N. B. Johnson, I. C. Lennon, P. H. Moran, J. A. Ramsden, Acc. Chem. Res. 2007, 40, 1291-1299.

[4] a) W. S. Knowles, M. J. Sabacky, Chem. Commun. (London) 1968 1445-1446; b) L. Horner, H. Siegel, H. Büthe, Angew. Chem. 1968, 80, 1034-1035; Angew. Chem. Int. Ed. Engl. 1968, 7, 942.

[5] For a review, see: W. Tang, X. Zhang, Chem. Rev. 2003, 103, 30293069.

[6] F. Guillen, J.-C. Fiaud, Tetrahedron Lett. 1999, 40, 2939-2942.

[7] A. Gillon, K. Heslop, D. J. Hyett, A. Martorell, A. G. Orpen, P. G. Pringle, C. Claver, E. Fernandez, Chem. Commun. 2000, 961-962.

[8] a) M. T. Reetz, T. Sell, Tetrahedron Lett. 2000, 41, 6333-6336; b) M. T. Reetz, G. Mehler, Angew. Chem. 2000, 112, 4047-4049; Angew. Chem. Int. Ed. 2000, 39, 3889-3890.

[9] M. van den Berg, A. J. Minnaard, E. P. Schudde, J. van Esch, A. H. M. de Vries, J. G. de Vries, B. L. Feringa, J. Am. Chem. Soc. 2000, 122, 11539-11540.

[10] For recent reviews on monodentate ligands, see: a) P. W. N. M. van Leeuwen, P. C. J. Kamer, C. Claver, O. Pa'mies, M. Die'guez, Chem. Rev. 2011, 111, 2077-2118; b) J. F. Teichert, B. L. Feringa, Angew. Chem. 2010, 122, 2538-2582; Angew. Chem. Int. Ed. 2010, 49, 24862528; c) T. Jerphagnon, J.-L. Renaud, C. Bruneau, Tetrahedron: Asymmetry 2004, 15, 2101-2111.
[11] a) M. T. Reetz, T. Sell, A. Meiswinkel, G. Mehler, Patent application DE-A 10247633.0 (11-10-2002); b) M. T. Reetz, T. Sell, A. Meiswinkel, G. Mehler, Angew. Chem. 2003, 115, 814-817; Angew. Chem. Int. Ed. 2003, 42, 790-793; c) M. T. Reetz, G. Mehler, Tetrahedron Lett. 2003, 44, 4593-4596.

[12] a) D. Peña, A. J. Minnaard, J. A. F. Boogers, A. H. M. de Vries, J. G. de Vries, B. L. Feringa, Org. Biomol. Chem. 2003, 1, 1087-1089 b) A. Duursma, R. Hoen, J. Schuppan, R. Hulst, A. J. Minnaard, B. L. Feringa, Org. Lett. 2003, 5, 3111-3113.

[13] For a review on this approach, see: M. T. Reetz, Angew. Chem. 2008, 120, 2592-2626; Angew. Chem. Int. Ed. 2008, 47, 2556-2588.

[14] For an alternative, non-supramolecular approach, see: L. Pignataro, B. Lynikaite, R. Colombo, S. Carboni, M. Krupička, U. Piarulli, C. Gennari, Chem. Commun. 2009, 3539-3541.

[15] For relevant reviews, see: a) B. Breit, Angew. Chem. 2005, 117, 6976-6986; Angew. Chem. Int. Ed. 2005, 44, 6816-6825; b) M. J. Wilkinson, P. W. N. M. van Leeuwen, J. N. H. Reek, Org. Biomol. Chem. 2005, 3, 2371-2383; c) A. J. Sandee, J. N. H. Reek, Dalton Trans. 2006, 3385-3391; d) P. W. N. M. van Leeuwen, Supramolecular Catalysis, Wiley-VCH, Weinheim, 2008; e) P. E. Goudriaan, P. W. N. M. van Leeuwen, M.-N. Birkholz, J. N. H. Reek, Eur. J. Inorg. Chem. 2008, 2939-2958; f) G. Gasparini, M. Dal Molin, L. J. Prins, Eur. J. Org. Chem. 2010, 2429-2440; g) J. Meeuwissen, J. N. H. Reek, Nat. Chem. 2010, 2, 615-621; h) S. Carboni, C. Gennari, L. Pignataro, U. Piarulli, Dalton Trans. 2011, 40, 4355-4373.

[16] For examples of ligand-ligand hydrogen-bonding interactions, see a) B. Breit, W. Seiche, J. Am. Chem. Soc. 2003, 125, 6608-6609; b) B. Breit, W. Seiche, Angew. Chem. 2005, 117, 1666-1669; Angew. Chem. Int. Ed. 2005, 44, 1640-1643; c) F. Chevallier, B. Breit, Angew. Chem. 2006, 118, 1629-1632; Angew. Chem. Int. Ed. 2006, 45, 1599-1602; d) M. Weis, C. Waloch, W. Seiche, B. Breit, J. Am. Chem. Soc. 2006, 128, 4188-4189; e) Y. Liu, C. A. Sandoval, Y. Yamaguchi, X. Zhang, Z. Wang, K. Kato, K. Ding, J. Am. Chem. Soc. 2006, 128, 14212-14213; f) A. J. Sandee, A. M. van der Burg, J. N. H. Reek, Chem. Commun. 2007, 864-866; g) M.-N. Birkholz, N. V. Dubrovina, I. A. Shuklov, J. Holz, R. Paciello, C. Waloch, B. Breit, A Börner, Tetrahedron: Asymmetry 2007, 18, 2055-2060; h) M.-N. Birkholz, N. V. Dubrovina, H. Jiao, D. Michalik, J. Holz, R. Paciello, B. Breit, A. Börner, Chem. Eur. J. 2007, 13, 5896-5907; i) C. Waloch, J. Wieland, M. Keller, B. Breit, Angew. Chem. 2007, 119, 3097-3099; Angew. Chem. Int. Ed. 2007, 46, 3037-3039; j) G. Hattori, T. Hori, Y. Miyake, Y. Nishibayashi, J. Am. Chem. Soc. 2007, 129, 1293012931; k) Y. Li, Y. Feng, Y.-M. He, F. Chen, J. Pan, Q.-H. Fan, Tetrahedron Lett. 2008, 49, 2878-2881; 1) A. C. Laungani, B. Breit, Chem. Commun. 2008, 844-846; m) A. C. Laungani, J. M. Slattery, I. Krossing, B. Breit, Chem. Eur. J. 2008, 14, 4488-4502; n) B. Breit, Pure Appl. Chem. 2008, 80, 855-860; o) F. W. Patureau, M. Kuil, A. J. Sandee, J. N. H. Reek, Angew. Chem. 2008, 120, 3224-3227; Angew. Chem. Int. Ed. 2008, 47, 3180-3183; p) M. de Greef, B. Breit, Angew. Chem. 2009, 121, 559-562; Angew. Chem. Int. Ed. 2009, 48, 551-554; q) J. Meeuwissen, M. Kuil, A. M. van der Burg, A. J. Sandee, J. N. H. Reek, Chem. Eur. J. 2009, 15, 10272-10279; r) J. Meeuwissen, A. J. Sandee, B. de Bruin, M. A. Siegler, A. L. Spek J. N. H. Reek, Organometallics 2010, 29, 2413-2421.

[17] For examples of ligand-substrate supramolecular interactions, see: a) D. B. Grotjahn, Chem. Eur. J. 2005, 11, 7146-7153; b) I. Usui, S. Schmidt, M. Keller, B. Breit, Org. Lett. 2008, 10, 1207-1210; c) S. Das, C. D. Incarvito, R. H. Crabtree, G. W. Brudvig, Science 2006, 312, 1941-1943; d) T. Šmejkal, B. Breit, Angew. Chem. 2008, 120, 317-321; Angew. Chem. Int. Ed. 2008, 47, 311-315; e) T. Šmejkal, B. Breit, Angew. Chem. 2008, 120, 4010-4013; Angew. Chem. Int. Ed. 2008, 47, 3946-3949; f) L. Diab, T. Šmejkal, J. Geier, B. Breit, Angew. Chem. 2009, 121, 8166-8170; Angew. Chem. Int. Ed. 2009, 48, 8022-8026; g) P.-A. R. Breuil, F. W. Patureau, J. N. H. Reek Angew. Chem. 2009, 121, 2196-2199; Angew. Chem. Int. Ed. 2009, $48,2162-2165$; h) T. Šmejkal, D. Gribkov, J. Geier, M. Keller, B. Breit, Chem. Eur. J. 2010, 16, 2470-2478; i) P. Fackler, C. Berthold, F. Voss, T. Bach, J. Am. Chem. Soc. 2010, 132, 15911-15913. 
[18] For examples of ligand-ligand coordinative bonding interactions, see: a) V. F. Slagt, P. W. N. M. van Leeuwen, J. N. H. Reek, Chem. Commun. 2003, 2474-2475; b) V. F. Slagt, P. W. N. M. van Leeuwen, J. N. H. Reek, Angew. Chem. 2003, 115, 5777-5781; Angew. Chem. Int. Ed. 2003, 42, 5619-5623; c) V. F. Slagt, M. Röder, P. C. J. Kamer, P. W. N. M. van Leeuwen, J. N. H. Reek, J. Am. Chem. Soc. 2004, 126, 4056-4057; d) J. M. Takacs, D. S. Reddy, S. A. Moteki, D. Wu, H. Palencia, J. Am. Chem. Soc. 2004, 126, 4494-4495; e) J. N. H. Reek, M. Röder, P. E. Goudriaan, P. C. J. Kamer, P. W. N. M. van Leeuwen, V. F. Slagt, J. Organomet. Chem. 2005, 690, 4505-4516; f) J. M. Takacs, P. M. Hrvatin, J. M. Atkins, D. S. Reddy, J. L. Clark, New J. Chem. 2005, 29, 263-265; g) X.-B. Jiang, L. Lefort, P. E. Goudriaan, A. H. M. de Vries, P. W. N. M. van Leeuwen, J. G. de Vries, J. N. H. Reek, Angew. Chem. 2006, 118, 1245 1249; Angew. Chem. Int. Ed. 2006, 45, 1223-1227; h) M. Kuil, P. E. Goudriaan, P. W. N. M. van Leeuwen, J. N. H. Reek, Chem. Commun. 2006, 4679-4681; i) J. M. Takacs, K. Chaiseeda, S. A. Moteki, D. S. Reddy, D. Wu, K. Chandra, Pure Appl. Chem. 2006, 78, 501-509; j) J. M. Atkins, S. A. Moteki, S. G. DiMagno, J. M. Takacs, Org. Lett. 2006, 8, 2759-2762; k) V. F. Slagt, P. W. N. M. van Leeuwen, J. N. H. Reek, Dalton Trans. 2007, 2302-2310; 1) V. F. Slagt, P. W. N. M. van Leeuwen, J. N. H. Reek, Dalton Trans. 2007, 2302-2310; m) M. Kuil, P. E. Goudriaan, A. W. Kleij, D. M. Tooke, A. L. Spek, P. W. N. M. van Leeuwen, J. N. H. Reek, Dalton Trans. 2007, 2311-2320; n) X.-B. Jiang, P. W. N. M. van Leeuwen, J. N. H. Reek, Chem. Commun. 2007, 2287-2289; o) S. A. Moteki, J. M. Takacs, Angew. Chem. 2008, 120, 908-911; Angew. Chem. Int. Ed. 2008, 47, 894-897; p) P. E. Goudriaan, M. Kuil, X.-B. Jiang, P. W. N. M. van Leeuwen, J. G. de Vries, J. N. H. Reek, Dalton Trans. 2009, $1801-1805$.

[19] a) H. Gulyás, J. Benet-Buchholz, E. C. Escudero-Adan, Z. Freixa, P. W. N. M. van Leeuwen, Chem. Eur. J. 2007, 13, 3424-3430; b) C. Machut, J. Patrigeon, S. Tilloy, H. Bricout, F. Hapiot, E. Monflier, Angew. Chem. 2007, 119, 3100-3102; Angew. Chem. Int. Ed. 2007, 46, 3040-3042; c) B. Lynikaite, J. Cvengroš, U. Piarulli, C. Gennari, Tetrahedron Lett. 2008, 49, 755-759; d) L. Pignataro, B. Lynikaite, J. Cvengroš, M. Marchini, U. Piarulli, C. Gennari, Eur. J. Org. Chem. 2009, 2539-2547; e) O. Chuzel, C. Magnier-Bouvier, E. Schulz, Tetrahedron: Asymmetry 2008, 19, 1010-1019.

[20] For older reviews on this approach, see: a) M. Sawamura, Y. Ito, Chem. Rev. 1992, 92, 857-871; b) R. Breslow, Acc. Chem. Res. 1995, 28, 146-153; c) A. J. Kirby, Angew. Chem. 1996, 108, 770-790; Angew. Chem. Int. Ed. Engl. 1996, 35, 706-724; d) H. Steinhagen, G. Helmchen, Angew. Chem. 1996, 108, 2489-2492; Angew. Chem. Int. Ed. Engl. 1996, 35, 2339-2342; e) M. T. Reetz, Top. Catal. 1997, 4, 187-200; f) E. K. van den Beuken, B. L. Feringa, Tetrahedron 1998, 54, 12985-13011; g) G. J. Rowlands, Tetrahedron 2001, 57, $1865-1882$.

[21] a) C. Monti, C. Gennari, U. Piarulli, J. G. de Vries, A. H. M. de Vries, L. Lefort, Chem. Eur. J. 2005, 11, 6701-6717; b) C. Monti, C. Gennari, U. Piarulli, Chem. Commun. 2005, 5281-5283; c) C. Marelli, C. Monti, C. Gennari, U. Piarulli, Synlett 2007, 2213-2216; d) C. Monti, C. Gennari, U. Piarulli, Chem. Eur. J. 2007, 13, 1547-1558.

[22] For the preliminary results obtained with the PhthalaPhos ligands, see: L. Pignataro, S. Carboni, M. Civera, R. Colombo, U. Piarulli, C. Gennari, Angew. Chem. 2010, 122, 6783-6787; Angew. Chem. Int. Ed. 2010, 49, 6633-6637.

[23] G. V. Boyd, R. L. Monteil, J. Chem. Soc. Perkin Trans. 1 1978, $1338-$ 1350 .

[24] E. G. Díaz de Toranzo, J. A. Brieux, J. Med. Chem. 1967, 10, 982983.

[25] See reference [14], and the references therein.

[26] The use of this ligand in the hydrogenation of some substrates screened in this work had already been reported. For S1, see: a) reference [11a]. For S3, see: b) M. T. Reetz, G. Mehler, A. Meiswinkel, T. Sell, Tetrahedron: Asymmetry 2004, 15, 2165-2167; see also: c) reference [14]

[27] The use of this ligand in the hydrogenation of some substrates screened in this work has already been reported. For S1, see: a) M. T. Reetz, G. Mehler, A. Meiswinkel, patent application DE-A 10027505.2 (6-6-2000). For S3, see: b) reference [11a]; c) M. T. Reetz, G. Mehler, A. Meiswinkel, T. Sell, Tetrahedron Lett. 2002, 43, 7941-7943; see also: d) reference [26b].

[28] The absolute configuration of the product was assigned by comparison of the sign of the optical rotation with literature data; see: M. J. Burk, J. E. Feaster, W. A. Nugent, R. L. Harlow, J. Am. Chem. Soc. 1993, 115, 10125-10138.

[29] The absolute configuration of the product was assigned by comparison of the sign of the optical rotation with literature data; see: M.-J. Kim, W.-H. Kim, K. Han, Y. K. Choi, J. Park, Org. Lett. 2007, 9, 1157-1159.

[30] H. Bernsmann, M. van den Berg, R. Hoen, A. J. Minnaard, G. Mehler, M. T. Reetz, J. G. de Vries, B. L. Feringa, J. Org. Chem. 2005, 70, 943-951.

[31] a) Z. Zhang, G. Zhu, Q. Jiang, D. Xiao, X. Zhang, J. Org. Chem 1999, 64, 1774-1775. For the use of highly efficient biaryl-type bisphosphine ligands with a stereogenic axis in the rhodium-catalyzed hydrogenation reaction, see: b) W. Tang, Y. Chi, X. Zhang, Org Lett. 2002, 4, 1695-1698; c) Y. Zou, H. Geng, W. Zhang, S. Yu, X Zhang, Tetrahedron Lett. 2009, 50, 5777-5779, and references therein

[32] For key papers on the mechanism of the rhodium-catalyzed asymmetric hydrogenation reaction, see: a) J. Halpern, Science 1982, 217, 401-407; b) C. R. Landis, J. Halpern, J. Am. Chem. Soc. 1987, 109, 1746-1754; c) C. R. Landis, P. Hilfenhaus, S. Feldgus, J. Am. Chem. Soc. 1999, 121, 8741-8754; d) S. Feldgus, C. R. Landis, J. Am. Chem. Soc. 2000, 122, 12714-12727; e) C. R. Landis, S. Feldgus, Angew. Chem. 2000, 112, 2985-2988; Angew. Chem. Int. Ed. 2000, 39, $2863-$ 2866 ; f) R. Giernoth, H. Heinrich, N. J. Adams, R. J. Deeth, J. Bargon, J. M. Brown, J. Am. Chem. Soc. 2000, 122, 12381-12382 g) H. Heinrich, R. Giernoth, J. Bargon, J. M. Brown, Chem Commun. 2001, 1296-1297; h) I. D. Gridnev, T. Imamoto, Acc. Chem. Res. 2004, 37, 633-644; i) I. D. Gridnev, T. Imamoto, Chem. Commun. 2009, 7447-7464.

[33] a) M. T. Reetz, A. Meiswinkel, G. Mehler, K. Angermund, M. Graf, W. Thiel, R. Mynott, D. G. Blackmond, J. Am. Chem. Soc. 2005 , 127, 10305-10313; b) I. D. Gridnev, C. Fan, P. G. Pringle, Chem Commun. 2007, 1319-1321; c) L. Schiaffino, G. Ercolani, J. Phys. Org. Chem. 2011, 24, 257-261.

[34] The octahedral dihydrides were not identified as the transition states of the stereodiscriminating step. Therefore, a quantitative energy comparison between the re and si dihydride intermediates would be irrelevant. However, following a suggestion by one of the referees, structure $r e \mathbf{- 7} \mathbf{b}$, leading to the experimentally minor $S$ enantiomer (corresponding to $r e$-face coordination) was calculated using the same computational workflow as reported for dihydride si7b. In the DFT-optimized structure of $r e-7 \mathbf{b}$ (shown below) a hydrogen bond is present between the carbonyl oxygen of the amide group of $\mathbf{4 a}$ (the amide group that is connected to the phosphite group) and the $\mathrm{NH}$ of the substrate. The optimized octahedral dihy-
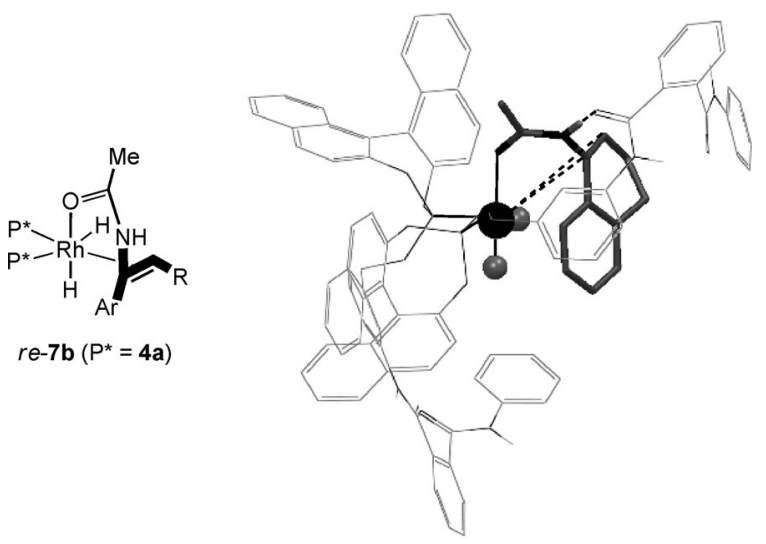
dride structure $s i-7 \mathbf{b}$ is more-stable than $r e-7 \mathbf{b}$ by $2.52 \mathrm{kcalmol}^{-1}$. The DFT-optimized structure of dihydride $r e-\mathbf{7 b}$. Wires (P ligands) and tubes (substrate $\mathbf{S 4}$ ): $\mathrm{C}=$ gray, amide $\mathrm{H}=$ light gray, heteroatoms $(\mathrm{N}, \mathrm{O}, \mathrm{P})=$ black; $\mathrm{CPK}$ spheres: $\mathrm{Rh}=$ black, $\mathrm{H}=$ gray. For the sake of clarity, all $\mathrm{H}$ atoms bound to carbon are omitted.

[35] All DFT calculations were performed using Jaguar Version 7.7 (Schrödinger, LLC, New York, NY). For DFT calculations of supramolecular bidentate rhodium complexes, see reference $[17 \mathrm{~g}]$.

[36] All calculations were run using the Schrödinger suite of programs (http://www.schrodinger.com) through the Maestro graphical interface. The Monte Carlo/Energy Minimization (MC/EM) conformational search (see reference [37]) was performed within the framework of MacroModel Version 9.7 (Schrödinger, LLC, New York, NY) using the MacroModel implementation of the Amber all-atom force field (denoted AMBER*, see reference [38a]) and the chloroform GB/SA solvation model (see reference [38b]).

[37] G. Chang, W. C. Guida, W. C. Still, J. Am. Chem. Soc. 1989, 111, $4379-4386$
[38] a) S. J. Weiner, P. A. Kollman, D. T. Nguyem, D. A. Case, J. Comput Chem. 1986, 7, 230-252; b) W. C. Still, A. Tempczyk, R. C. Hawley, T. Hendrickson, J. Am. Chem. Soc. 1990, 112, 6127-6129.

[39] a) N. V. Dubrovina, I. A. Shuklov, M.-N. Birkholz, D. Michalik, R. Paciello, A. Börner, Adv. Synth. Catal. 2007, 349, 2183-2187; b) I. A. Shuklov, N. V. Dubrovina, E. Barsch, R. Ludwig, D. Michalik, A. Börner, Chem. Commun. 2009, 1535-1537.

[40] M. van den Berg, B. L. Feringa, A. J. Minnaard in Handbook of Homogeneous Hydrogenation (Eds.: J. G. de Vries, C. J. Elseiver), WILEY-VCH, Weinheim, 2007, 995-1027.

[41] M. Noji, T. Ohno, K. Fuji, N. Futaba, H. Tajima, K. Ishii, J. Org Chem. 2003, 68, 9340-9347.

[42] D. Basavaiah, K. Muthukumaran, B. Sreenivasulu, Synthesis 2000, 545-548.

[43] W. C. Still, M. Kahn, A. Mitra, J. Org. Chem. 1978, 43, 2923-2925.

Received: June 30, 2011 Published online: December 28, 2011 